DD Bock

n Annotated Key to

of Algae Observed in the Phytoplank Genera

of the United States

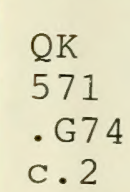



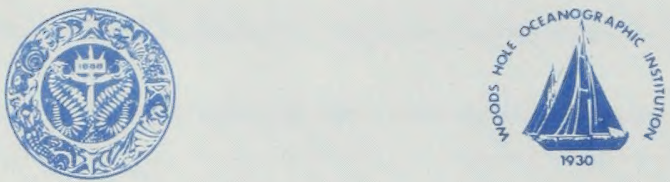

MBL/WHOI

LIBRARY

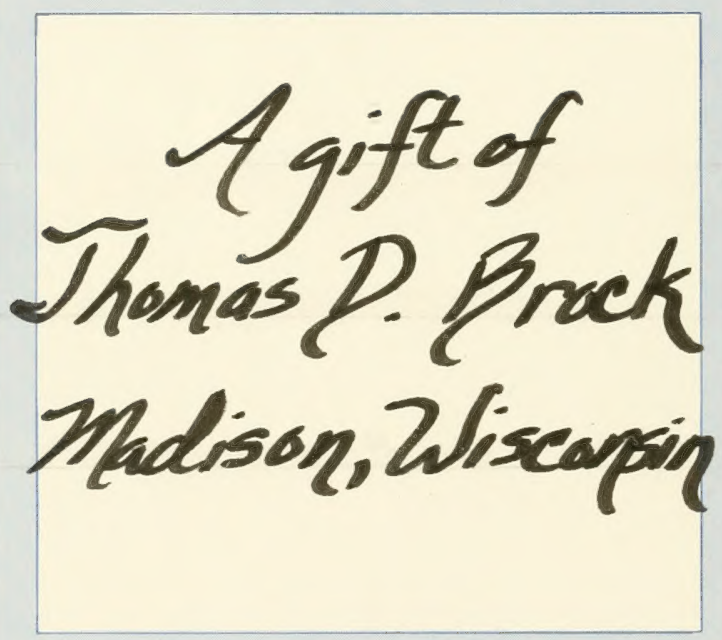


An Annotated Key to the Identification of Commonly Occurring and Dominant Genera of Algae Observed in the Phytoplankton of the United States

By PHILLIP E. GREESON

GEOLOGICAL SURVEY WATER-SUPPLY PAPER 2079
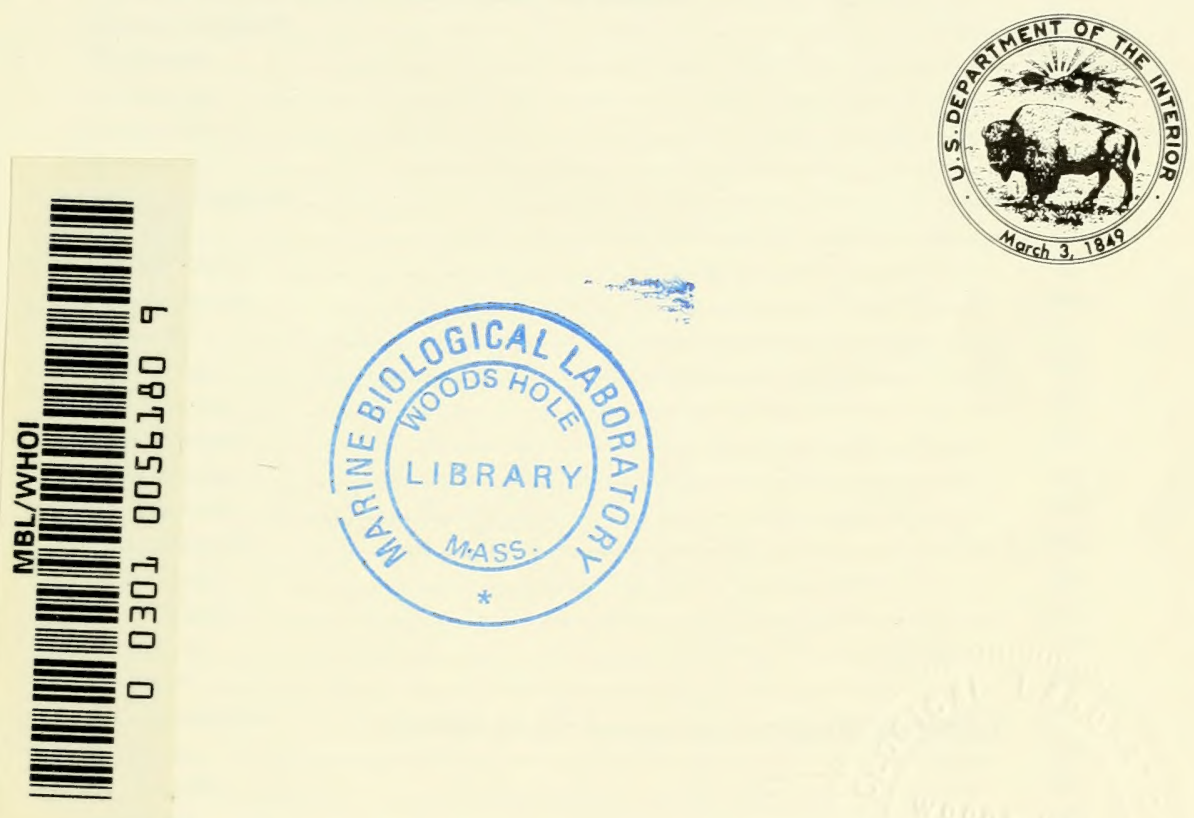
UNITED STATES DEPARTMENT OF THE INTERIOR

JAMES G. WATT, Secretary

GEOLOGICAL SURVEY

Dallas L. Peck, Director

Library of Congress catalog-card No. 81-600168

For sale by the Superintendent of Documents, U.S. Government Printing Office Washington, D.C. 20402 


\section{CONTENTS}

Abstract

Introduction

Acknowledgment

Taxonomic key to the identification of commonly occurring and dominant genera of algae observed in the phytoplankton of the United States

Descriptions of the genera

Chlorophyta

Actinastrum

Ankistrodesmus

Chlamydomonas

Chodatella

Coelastrum

Cosmarium

Crucigenia

Dictyosphaerium

Golenkinia

Kirchneriella

Micractinium

Oocystis

Pandorina

Pediastrum

Scenedesmus

Schroederia

Selenastrum

Sphaerocystis

Tetraedron

Tetrastrum

Euglenophyta

Euglena

Trachelomonas

Chrysophyta

Achnanthes

Amphora

Asterionella

Cocconeis

Cyclotella

Cymbella

Diatoma

Dinobryon

Epithemia

Eunotia

Fragilaria

Gomphonema

Gyrosigma 
Descriptions of the genera- Continued

Chrysophyta - Continued

Melosira _-_-_-_-_-_- 84

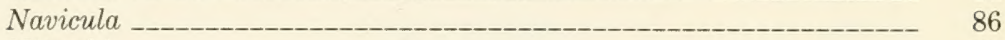

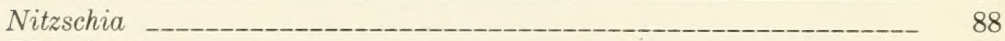

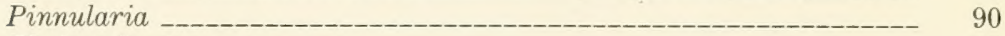

Rhoicosphenia _-_- 92

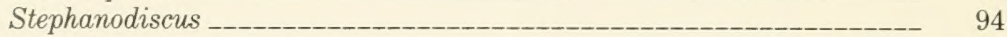

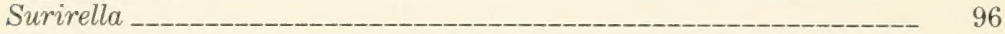

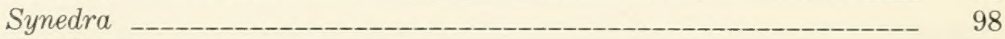

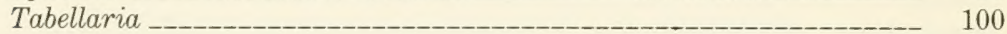

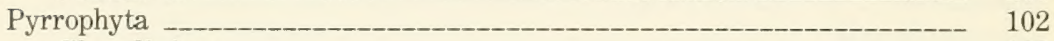

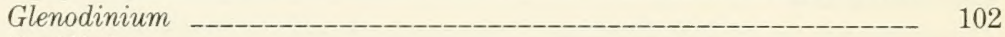

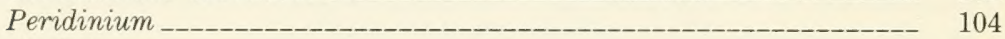

Cryptophyta _-_ 106

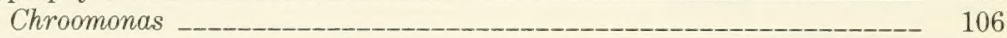

Cryptomonas _-_- 108

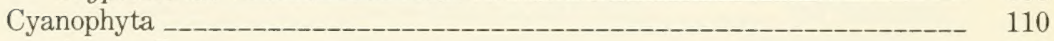

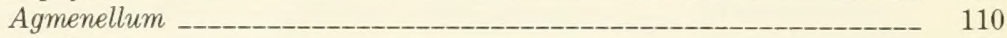

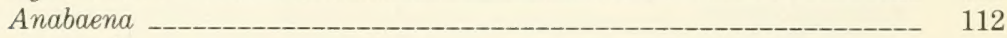

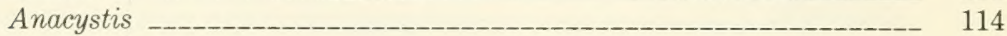

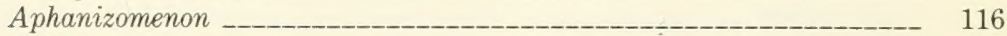

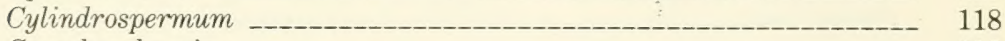

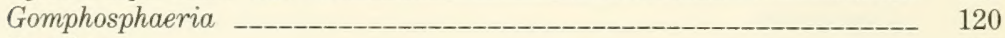

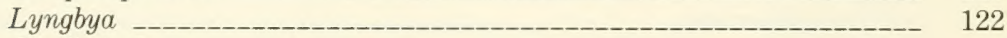

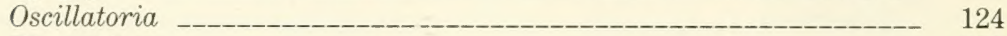

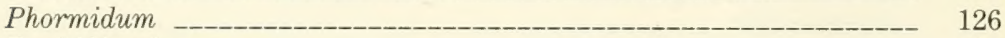

Glossary

Raphidiopsis -_-_- 128

Selected references

\section{ILLUSTRATIONS}

Figures 1-4. Drawings of:

1. Actinastrum -- 15

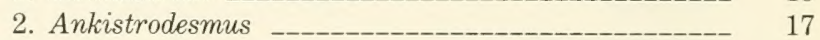

3. Chlamydomonas _- 19

4. Chodatella _- 21

5. Photomicrograph of Coelastrum -23

6, 7. Drawings of:

6. Cosmarium

7. Crucigenia _- 27

8. Photomicrograph of Dictyosphaerium

9, 10. Drawings of:

9. Golenkinia

10. Kirchneriella

11, 12. Photomicrographs of:

11. Micractinium

12. Oocystis _- 37

13. Drawing of Pandorina 
Figures 14, 15. Photomicrographs of:

14. Pediastrum.

15. Scenedesmus

16-20. Drawings of:

16. Schroederia

17. Selenastrum

18. Sphaerocystis

19. Tetraedron

20. Tetrastrum

21-25. Photomicrographs of:

21. Euglena

22. Trachelomonas _-_-_-_-_-_-_-_-_-_-_-_-_-_-_ 57

23. Achnanthes -- 59

24. Amphora - 61

25. Asterionella

26, 27. Scanning electronmicrographs of:

26. Cocconeis

27. Cyclotella

28-30. Photomicrographs of:

28. Cymbella

29. Diatoma

30. Dinobryon

31. Scanning electronmicrograph of Epithemia

32. Drawing of Eunotia

33-35. Photomicrographs of:

33. Fragilaria

79

34. Gomphonema

35. Gyrosigma

36. Scanning electronmicrograph of Melosira

81

83

37-40. Photomicrographs of:

37. Navicula

38. Nitzschia

39. Pinnularia

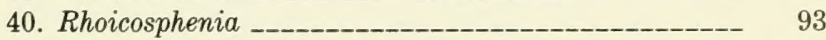

41. Scanning electronmicrograph of Stephanodiscus ________ 95

42. Photomicrograph of Surirella

43. Drawing of Synedra

44, 45. Photomicrographs of:

44. Tabellaria

45. Glenodinium

46-48. Drawings of:

46. Peridinium

47. Chroomonas

48. Cryptomonas

49-52. Photomicrographs of:

49. Agmenellum

50. Anabaena

51. Anacystis

52. Aphanizomenon

53, 54. Drawings of:

53. Cylindrospermum

54. Gomphosphaeria 
Figures 55, 56. Photomicrographs of:

55. Lyngbya

56. Oscillatoria

57, 58. Drawings of:

57. Phormidium

58. Raphidiopsis

TABLES

TABLE 1. List of algal genera observed in the phytoplankton of the United States

2. Commonly occurring genera of algae observed in the phytoplankton of the United States

3. Dominant genera of algae observed in the phytoplankton of the United States

4. Taxonomic groupings of commonly occurring and dominant genera of algae of the United States

A Note on the Illustrations in this Book:

The drawings of alga genera shown in figures $1,2,3,4,6,7,9,10,13,16,17,18,19$, $20,32,43,46,47,48,53,54,57,58$ were redrawn from originals in Smith, 1950, published by the McGraw-Hill Book Company and are shown here under 1 icense from McGraw-Hill. The scanning electron-micrographs were made by Bruce W. Lium and W. Thomas Shoaf III, U.S. Geological Survey. The photomicrographs were made by the author. 


\title{
AN ANNOTATED KEY TO THE IDENTIFICATION OF COMMONLY OCCURRING AND DOMINANT GENERA OF ALGAE OBSERVED IN THE PHYTOPLANKTON OF THE UNITED STATES
}

\author{
By PHILLIP E. GREESON
}

\section{ABSTRACT}

In early 1979 , a retrieval was made for all phytoplankton data contained in the computerized data file of the U. S. Geological Survey. The retrieval revealed the analytical results of 17,959 samples collected and processed between October 1973 and October 1978. Of the approximately 500 genera of freshwater algae reported in the United States, the U.S. Geological Survey observed 321 genera in the phytoplankton. Fifty-two genera were considered to be commonly occurring and 42 genera were considered to be community dominants. The report lists, describes, and provides a detailed taxonomic key to the identification of 58 genera of algae considered either commonly occurring or dominant. Also included is a summary of environmental conditions under which each algal genus was observed, as well as a glossary and an extensive list of selected references.

\section{INTRODUCTION}

Taxonomy is the science concerned with the orderly arrangement of organisms in some scheme of likenesses and differences among the various individuals. The present taxonomic system was developed mostly during the 18th and 19th centuries. During the mid-1800's, taxonomy played an additional and equally important role, that being the basic tool in the analysis of evolutionary relationships among organisms. This is commonly called the science of systematics. It was in the early-1900's when investigators began to realize that organisms not only had certain inherent relationships but also were sensitive to changes in the environment.

Since the beginning of the 20th century, numerous publications have discussed algae as indicators of environmental conditions. Perhaps the most important contribution on ecological indicators was by Kolkwitz and Marrson (1908), who introduced the concept of indicator species. This resulted in the "saprobian" system for classifying organisms in organically polluted rivers.

After the paper by Kolkwitz and Marrson, many similar papers were published; all discussed indicator species. The importance of biological indicators as an index of pollution was described by Forbes (1913), 
when he stated that $“ * * *$ it is quite possible to arrange plants and animals of a stream in the order of their preference for, or tolerance of, organic impurities, in such a way that a graded list of them may serve as an index to grades of contamination."

W. C. Purdy (1922), a plankton specialist with the U.S. Public Health Service, clearly recognized the value of biological indicators when he concluded, "If it be true that the biological life of a stream is distinctly and profoundly affected by the numerous factors which form the environment, it follows that the organisms in a stream constitute in a general way a reflection of the prevailing environmental conditions of the stream."

Thienemann (1939) was the first to demonstrate that groups of species were characteristic of a given type of environment. Community structure as an indicator of environmental conditions thereby became a firmly established concept. Fjerdingstad (1950) was the first to consider algal community-dominant species, associate species, and accidental species. Perhaps the most well known paper considering community structure as an indicator was by Patrick (1949). In it, she coined the terms "healthy," "semihealthy," "polluted," and "very polluted" to describe the variability one might expect in the organisms and yet indicate the degree of degradation that had taken place in a stream.

Subsequent to Patrick's paper, the emphasis changed from studies that were purely qualitative in nature to quantitative expressions of community structures, associations, and diversities.

With the realization of the importance of biota as indicators and of the need to characterize the quality of water, including the biological quality, in major waterways of the United States, the U.S. Public Health Service initiated the National Water Quality Network in 1957. Samples for determining the physical, chemical, and biological quality at 128 stations were collected through 1962 (Williams, 1962, 1964, 1966). The network continued until the late 1960's as the Water Pollution Surveillance System under the purview of the Federal Water Pollution Control Administration (now the U.S. Environmental Protection Agency) (Weber, 1966).

The changing emphasis toward the preservation of environmental quality during the 1960's awakened the need for a long-term data base with which changes in water quality could be determined. As a result, the U.S. Geological Survey initiated the National Stream-Quality Accounting Network (NASQAN) in 1973. NASQAN is a series of stations at which systematic and continuing measurements are made to determine the quality of the Nation's streams. Design of the network specifies measurement of a broad range of water-quality characteristics, including biological characteristics, which were selected to meet many of the information requests of groups involved 
in planning and management on a national or regional scale. The primary objectives of NASQAN are (1) to account for the quantity and quality of surface water moving within and from the United States, (2) to depict areal variability, (3) to detect changes in stream quality, and (4) to provide the groundwork for future assessments of changes in stream quality (Ficke and Hawkinson, 1975).

As part of NASQAN, phytoplankton samples are obtained seven times a year from about 540 stations. The samples are processed for generic identification and enumeration by the U.S. Geological Survey's Central Water-Quality Laboratory in Atlanta, Ga., in accord with the methods of Greeson and others (1977) and Greeson (1979). All data are stored in the computerized data files (WATSTORE and BIOTAB) of the U.S. Geological Survey.

In early 1979 , a retrieval was made for all phytoplankton data contained in BIOTAB. The data included those collected as part of NASQAN, as well as those data collected as part of other activities of the U.S. Geological Survey. About 80 percent of the file represented NASQAN data. During the 5-year period between October 1973 and October 1978, a total of 17,959 phytoplankton samples were processed. Using the almost 18,000 samples as a basis, this publication lists, describes, and provides a detailed taxonomic key for the identification of commonly occurring and dominant genera of algae observed in the phytoplankton of the United States. A summary of environmental conditions under which each algal genus was observed is included. Also included is a glossary and an extensive list of selected references.

Of the approximately 500 genera of freshwater algae reported in the United States (Greeson, 1970), the U.S. Geological Survey has observed 321 genera in the phytoplankton (table 1). Fifty-two genera reported in 5 percent or more of the samples were considered to be commonly occurring (table 2). Forty-two genera were dominant in 1 percent or more of the samples (table 3). A dominant genus was considered to be one that comprises 15 percent or more of the total cell count of a sample. Table 4 lists in alphabetical order by taxonomic groupings the 58 genera of algae that were either commonly occurring or dominant in the samples.

\section{ACKNOWLEDGMENT}

The author acknowledges with sincerest appreciation the many persons of the U.S. Geological Survey who made this publication possible. A special thanks is extended to James M. Bergmann, developer of $\mathrm{BIOTAB}$, for his assistance with data retrievals; to the field personnel who performed their duties under extremely demanding conditions; and to the supervisors and analysts in the U.S. Geological Survey's laboratory in Atlanta for their perseverance in spite of an overwhelming number of samples. 
TABLE 1. - List of algal genera observed in the phytoplankton of the United States

CHLOROPHYTA (Green algae)

Acanthosphaera

Actidesmium

Actinastrum

Ankistrodesmus

Ankyra

Arthrodesmus

Asterococcus

Bambusina

Binuclearia

Bohlinia

Botryococcus

Brachiomonas

Carteria

Cephalmonas

Cerasterias

Chaetophora

Characium

Chlamydomonas

Chlorella,

Chlorochytrium

Chlorococcum

Chlorogonium

Chloromonas

Chlorosarcina

Chodatella

Cladophora

Closteridium

Closteriopsis

Closterium

Coccomonas

Coelastrum

Coleochaete

Coronastrum

Cosmarium

Cosmocladium

Crucigenia

Cylindrocapsa

Cylindrocystis

\section{Dactylococcus}

Dactylothece

Desmatractum

Desmidium

Dichotomococcus

Dictyosphaerium

Dimorphococcus

Dispora

Dunaliella

Dysmorphococcus

Echinosphaerella Elakatothrix

Eremosphaera

Errerella

Euastropsis
Euastrum

Eudorina

Eutetramorus

Franceia

Fridaea

Geminella

Gloeoactinium

Gloeocystis

Golenkinia

Golenkiniopsis

Gonatozygon

Gonium

Haematococcus

Heteromastix

Hormidium

Hormotila

Hyalotheca

Hydrodictyon

Kirchneriella

Lobomonas

Mesostigma

Mesotaenium

Micractinium

Micrasterias

Microspora

Mougeotia

Mougeotiopsis

Nannochloris

Nephrocytium

Netriurr

Oedogonium

Onychonema

Oocystis

Ourococeus

Pachycladon

Palmella

Palmellococcus

Palmodictyon

Pandorina

Pediastrum

Penium

Phacotus

Phyllobium

Phymatodocis

Planktosphaeria

Platydorina

Platymonas

Pleodorina
Pleurotaenium

Polyedriopsis

Polytoma

Protococcus

Protosiphon

Pteromonas

Pyramimonas

Pyrobotrys

Quadricoccus

Quadrigula

Radiococeus

Raphidonema

Rhizoclonium

Rhodochytrium

Roya

Scenedesmus

Schizochlamys

Schroederia

Selenastrum

Sorastrum

Spermatozoopsis

Sphaerellopsis

Sphaerocystis

Sphaerozosma

Spirogyra

Spondylomomum

Spondylosium

Staurastrum

Stichococcus

Stigeoclonium

Stylosphaeridium

Tetmemomus

Tetradesmus

Tetraedron

Tetrallantos

Tetraspora

Tetrastrum

Thoracomonas

Trebouxia

Treubaria

Trochiscia

Ulothrix

Uronema

Volvox

Westella

Wislouchiella

Xanthidium

Zygnema

Zygnemopsis

EUGLENOPHYTA (Euglenoids)

Astasia

Calcycimonas

Colacium

Cryptoglena

Distigma
Euglena

Euglenopsis

Eutreptia

Lepocinclis

Menoidium
Phacus

Protochrysis

Strombomonas

Trachelomonas 
TABLE 1. - List of algal genera observed in the phytoplankton of the United States-Continued

\section{CHRYSOPHYTA}

Chrysophytes

$\begin{array}{lll}\text { Amphichrysis } & \text { Diachros } & \text { Perone } \\ \text { Botrydiopsis } & \text { Dinobryon } & \text { Peroniella } \\ \text { Bumilleriopsis } & \text { Epipyxis } & \text { Rhizochrysis } \\ \text { Centritractus } & \text { Gloeochloris } & \text { Stipitococcus } \\ \text { Characiopsis } & \text { Harpochytrium } & \text { Symura } \\ \text { Chlorallanthus } & \text { Hydrurus } & \text { Tribonema } \\ \text { Chlorellidiopsis } & \text { Kephyrion } & \text { Uroglena } \\ \text { Chlorobotrys } & \text { Mallomonas } & \text { Uroglenopsis } \\ \text { Chromulina } & \text { Mischococcus } & \\ \text { Chrysamoeba } & \text { Ochromonas } & \\ \text { Chrysochromulina } & \text { Olisthodiscus } & \\ \text { Chrysococcus } & \text { Ophiocytium } & \\ \text { Chrysosphaerella } & & \\ \text { Cyclonexis } & & \end{array}$

\section{CHRYSOPHYTA}

\section{Diatoms}

Achnanthes Actinella Actinocyclus Amphicampa Amphipleura Amphora Anomoeoneis Asterionella Attheya Auliscus

Biddulphia

Caloneis

Campylodiscus

Cerataulina

Chaetoceros

Cocconeis

Coscinodiscus

Cyclotella

Cylindrotheca

Cymbella

Denticula

Diatoma

Diatomella

Diploneis
Entomoneis

Epithemia

Eunotia

Fragilaria

Frustulia

Gomphoneis

Gomphonema

Guinardia

Gyrosigma

Hannaea

Hantzschia

Hemiaulus

Hyalodiscus

Licmophora

Mastogloia

Melosira

Meridion

Navicula

Neidium

Nitzschia
Opephora

Pinnularia

Plagiotropsis

Pleurosigma

Rhabdonema

Rhizosolenia

Rhoicosphenia

Rhapalodia

Scoliopleura

Skeletonema

Stauroneis

Stephanodiscus

Stephanopyxis

Streptotheca

Surirella

Synedra

Tabellaria

Terpsinoe

Tetracyclus

Thalassiosira

\section{PHYRROPHYTA (Dinoflagellates)}

\begin{tabular}{lll}
\hline Amphidinium & Glenodinium & Hemidinium \\
Ceratium & Gonyaulax & Massartia \\
Dinophysis & Gymnodinium & Oxyphysis \\
Exuviaella & Gyrodinium & Peridinium \\
& & Prorocentrum
\end{tabular}

\section{CRYPTOPHYTA (Cryptomonads)}

$\begin{array}{lll}\text { Chilomonas } & \text { Cryptomonas } & \text { Rhodomonas } \\ \text { Chroomonas } & \text { Cyanomonas } & \end{array}$


TABLE 1. - List of algal genera observed in the phytoplankton of the United States-Continued

\begin{tabular}{lll}
\hline & CYANOPHYTA (Blue-green algae) & \\
\hline Agmenellum & Gloeocapsa & Nostoc \\
Anabaena & Gloeotrichia & Oscillatoria \\
Anabaenopsis & Gomphosphaeria & Phormidium \\
Anacystis & Hydrocoleum & Plectonema \\
Arthrospira & Porphyrosiphon \\
Borzia & Isocystis & Raphidiopsis \\
Calothrix & Johannesbaptistia & Rivularia \\
Coccochloris & Kyrkia & Schizothrix \\
Dactylococcopsis & Lyngbya & Spirulina \\
Entophysalis & Microcoleus & Tetrapedia \\
& Nodularia & Trichodesmium
\end{tabular}

\section{RHODOPHYTA (Red algae)}

Audouinella Bangia

TABLE 2.-Commonly occurring genera of algae observed in the phytoplankton of the United States

\begin{tabular}{|c|c|c|}
\hline Genus & $\begin{array}{l}\text { Number of } \\
\text { occurrence }^{1}\end{array}$ & Percent \\
\hline $\begin{array}{l}\text { Nitzschia } \\
\text { Navicula } \\
\text { Cyclotella } \\
\text { Scenedesmus } \\
\text { Ankistrodesmus } \\
\text { Melosira }\end{array}$ & $\begin{array}{r}13,480 \\
12,374 \\
11,161 \\
8,580 \\
8,161 \\
7,446\end{array}$ & $\begin{array}{l}75 \\
69 \\
62 \\
48 \\
45 \\
41\end{array}$ \\
\hline $\begin{array}{l}\text { Synedra } \\
\text { Gomphonema } \\
\text { Anacystis } \\
\text { Oscillatoria }\end{array}$ & $\begin{array}{l}7,001 \\
6,519 \\
5,852 \\
5,556\end{array}$ & $\begin{array}{l}39 \\
36 \\
33 \\
31\end{array}$ \\
\hline $\begin{array}{l}\text { Achnanthes } \\
\text { Cymbella } \\
\text { Chlamydomonas } \\
\text { Cocconeis } \\
\text { Diatoma } \\
\text { Trachelomonas }\end{array}$ & $\begin{array}{l}4,962 \\
4,938 \\
4,649 \\
4,182 \\
3,906 \\
3,625\end{array}$ & $\begin{array}{l}28 \\
27 \\
26 \\
23 \\
22 \\
20\end{array}$ \\
\hline $\begin{array}{l}\text { Fragilaria } \\
\text { Surirella } \\
\text { Euglena } \\
\text { Kirchneriella } \\
\text { Asterionella } \\
\text { Oocystis } \\
\text { Dictyosphaerium }\end{array}$ & $\begin{array}{l}3,255 \\
2,984 \\
2,763 \\
2,580 \\
2,538 \\
2,518 \\
2,446\end{array}$ & $\begin{array}{l}18 \\
17 \\
15 \\
14 \\
14 \\
14 \\
14\end{array}$ \\
\hline $\begin{array}{l}\text { Crucigenia } \\
\text { Cryptomonas } \\
\text { Anabaena } \\
\text { Lyngbya } \\
\text { Rhoicosphenia } \\
\text { Agmenellum } \\
\text { Tetraedron }\end{array}$ & $\begin{array}{l}2,289 \\
2,226 \\
2,164 \\
2,080 \\
1,952 \\
1,849 \\
1,793\end{array}$ & $\begin{array}{l}13 \\
12 \\
12 \\
12 \\
11 \\
10 \\
10\end{array}$ \\
\hline
\end{tabular}


TABLE 2.-Commonly occurring genera of algae observed in the phytoplankton of the United States-Continued

\begin{tabular}{|c|c|c|}
\hline Genus & $\begin{array}{l}\text { Number of } \\
\text { occurrence }^{1}\end{array}$ & Percent \\
\hline Actinastrum & 1,672 & 9 \\
\hline Pediastrum & 1,611 & 9 \\
\hline Micractinium & 1,499 & 8 \\
\hline Schroederia & 1,413 & 8 \\
\hline Amphora & 1,409 & 8 \\
\hline Tetrastrum & 1,315 & 7 \\
\hline Gyrosigma & 1,288 & 7 \\
\hline Epithemia & 1,261 & 7 \\
\hline Coelastrum & 1,250 & 7 \\
\hline Dinobryon _- & 1,247 & 7 \\
\hline Pinnularia & 1,230 & 7 \\
\hline Selenastrum _._. & 1,222 & 7 \\
\hline Aphanizomenon & 1,127 & 6 \\
\hline Stephanodiscus _- & 1,092 & 6 \\
\hline Chroomonas - & 1,027 & 6 \\
\hline Glenodinium & 962 & 5 \\
\hline Peridinium _- & 950 & 5 \\
\hline Eunotia & 879 & 5 \\
\hline Chodatella & 852 & 5 \\
\hline Golenkinia & 847 & 5 \\
\hline Cosmarium & 817 & 5 \\
\hline
\end{tabular}

\footnotetext{
${ }^{1}$ Based on 17,959 samples.
}

TABLE 3.-Dominant genera 1 of algae observed in the phytoplankton of the United States

\begin{tabular}{|c|c|c|}
\hline Genus & $\begin{array}{c}\text { Number of } \\
\text { dominances }\end{array}$ & Percent \\
\hline Nitzschia ______._-_. & 3,530 & 20 \\
\hline Oscillatoria & 3,402 & 19 \\
\hline Cyclotella & 3,362 & 19 \\
\hline Navicula _-_ & 3,361 & 19 \\
\hline Anacystis _- & 2,696 & 15 \\
\hline Melosira & 2,388 & 13 \\
\hline Scenedesmus _-__-_ & 1,831 & 10 \\
\hline Lyngbya __________-_ & 1,091 & 6 \\
\hline Synedra & 734 & 4 \\
\hline Achnanthes ................. & 732 & 4 \\
\hline Agmenellum _- & 701 & 4 \\
\hline Anabaena -- & 691 & 4 \\
\hline 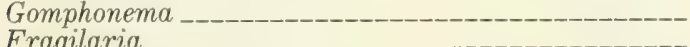 & 685 & 4 \\
\hline & 679 & 4 \\
\hline Asterionella & 543 & 3 \\
\hline Ankistrodesmus _-_- & 536 & 3 \\
\hline Aphanizomenon _- & 520 & 3 \\
\hline Diatoma & 429 & 2 \\
\hline Chlamydomonas _. & 375 & 2 \\
\hline Dictyosphaerium _-_ & 372 & 2 \\
\hline 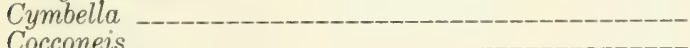 & 327 & 2 \\
\hline $\begin{array}{l}\text { Cocconers } \\
\text { Crucigenia. }\end{array}$ & $\begin{array}{l}306 \\
280\end{array}$ & $\begin{array}{l}2 \\
2\end{array}$ \\
\hline Gomphosphaeria & 266 & ${ }^{32}$ \\
\hline
\end{tabular}


TABLE 3.-Dominant genera ${ }^{1}$ of algae observed in the phytoplankton of the United States-Continued

\begin{tabular}{|c|c|c|}
\hline Genus & $\begin{array}{l}\text { Number of } \\
\text { dominances }^{2}\end{array}$ & Percent \\
\hline $\begin{array}{l}\text { Trachelomonas } \\
\text { Coelastrum } \\
\text { Actinastrum } \\
\text { Pediastrum }\end{array}$ & $\begin{array}{l}210 \\
209 \\
179 \\
171\end{array}$ & $\begin{array}{l}1 \\
1 \\
1 \\
1\end{array}$ \\
\hline $\begin{array}{l}\text { Micractinium } \\
\text { Cryptomonas } \\
\text { Oocystis } \\
\text { Dinobryon } \\
\text { Sphaerocystis - } \\
\text { Surirella } \\
\text { Cylindrospermum }\end{array}$ & $\begin{array}{l}170 \\
145 \\
145 \\
144 \\
144 \\
126 \\
124\end{array}$ & $\begin{array}{l}<1 \\
<1 \\
<1 \\
<1 \\
{ }^{3}<1 \\
<1 \\
{ }^{3}<1\end{array}$ \\
\hline $\begin{array}{l}\text { Chroomonas } \\
\text { Pandorina } \\
\text { Euglena } \\
\text { Phormidium } \\
\text { Eunotia } \\
\text { Raphidiopsis } \\
\text { Kirchneriella }\end{array}$ & $\begin{array}{r}120 \\
103 \\
97 \\
92 \\
91 \\
91 \\
79\end{array}$ & $\begin{array}{l}<1 \\
3<1 \\
3<1 \\
{ }^{3}<1 \\
<1 \\
{ }^{3}<1 \\
<1\end{array}$ \\
\hline
\end{tabular}

TABLE 4.-Taxonomic groupings of commonly occurring and dominant genera of algae of the United States

\section{CHLOROPHYTA (Green algae)}

Actinastrum
Ankistrodesmus
Chlamydomonas
Chodatella
Coelastrum
Cosmarium
Crucigenia

Dictyosphaerium

Golenkinia

Kirchneriella

Micractinium

Oocystis

Pandorina

Pediastrum
Scenedesmus

Schroederia

Selenastrum

Sphaerocystis

Tetraedron

Tetrastrum

\section{EUGLENOPHYTA (Euglenoids)}

Euglena Trachelomonas

\section{CHRYSOPHYTA (Chrysophytes and diatoms)}

\begin{tabular}{lll}
\hline Achnanthes & Epithemia & Nitzschia \\
Amphora & Eunotia & Pinnularia \\
Asterionella & Fragilaria & Rhoicosphenia \\
Cocconeis & Gomphonema & Stephanodiscus \\
Cyclotella & Gyrosigma & Surirella \\
Cymbella & Melosira & Synedra \\
Diatoma & Navicula & Tabellaria \\
Dinobryon & &
\end{tabular}

\section{PYRROPHYTA (Dinoflagellates)}

\begin{tabular}{lcl}
\hline Glenodinium & Peridinium & \\
\hline Chroomonas & Cryptomonas & \\
\hline \multicolumn{3}{c}{ CYANOPHYTA (Blue-green algae) } \\
\hline Agmenellum & Cylindrospermum & Oscillatoria \\
Anacystis & Gomphosphaeria & Phomidium \\
Aphanizomenon & Lyngbya & Raphidiopsis
\end{tabular}


TAXONOMIC KEY TO THE IDENTIFICATION OF COMMONLY

OCCURRING AND DOMINANT GENERA OF ALGAE

OBSERVED IN THE PHYTOPLANKTON OF THE

UNITED STATES

[The following key consists of couplets of characteristics. One must decide which statement of the couplet most accurately describes the specimen. Having made a selection, proceed to the couplet indicated by the number to the right. Continue through the key until a genus is indicated. The key is constructed for the 58 genera described in this report. The identification of other genera requires the use of a more comprehensive key.]

1A Plant pigments contained in chromatophores

or chloroplasts

1B Plant pigments not contained in chromatophores or chloroplasts, but diffused through protoplast

2A Plants filamentous; cells arranged

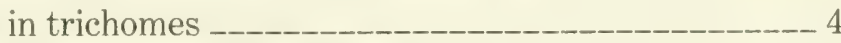

2B Plants colonial, not filamentous _-_-_-_-_-_-___-_-_-_ 3

$3 \mathrm{~A}$ Cells in regular rows, generally in multiples

of four; colony one cell in thickness

Agmenellum

3B Cells somewhat evenly arranged toward periphery of spherical colony; barely visible gelatinous strands radiate from center of colony to cells Gomphosphaeria

$3 \mathrm{C}$ Colony asymmetrical; cells very dense and unevenly distributed Anacystis

4A Filaments straight or slightly flexed 6

4B Filaments curved, twisted, or spiraled 5

$5 \mathrm{~A}$ Heterocysts and akinetes present Anabaena

5B Heterocysts absent Raphidiopsis

6 A Heterocysts present $-9$

6B Heterocysts absent 7

7A Filaments without a sheath; cells discoid Oscillatoria

7B Filaments with distinct sheath 8

8A Trichomes tangled; sheaths confluent Phormidium

8B Trichomes separate; sheaths not confluent 
9A Heterocysts terminal Cylindrospermum

9B Heterocysts intercalary Ahphanizomenon

$10 \mathrm{~A}$ Cell walls without punctae or striae

10B Cell walls rigid, ornamented with punctae or striae, indestructible by clearing techniques

11A Frustules adiametric, two or more times

longer than wide, generally elongate _-__-_________-_ 15

11B Frustules isodiametric, generally shorter in

length than in diameter, round or ellip-

tical or ovoid or nearly so

12A Frustules elliptical or ovoid or nearly so _-_-_-_-_-_-_-_-_-_-_-_-_-_-_-_-_-_-_-_ 14

12B Frustules discoid or nearly so __________________ 13

$13 \mathrm{~A}$ Valves radially punctate Stephanodiscus

13B Valves with two concentric regions, the in-

ner being smooth

14A Frustules with marginal keel Cyclotella

\section{containing a raphe} Surirella

14B Frustules with a pseudoraphe or with a raphe not in a marginal keel Cocconeis

15A Frustules cylindrical arranged end to end

into filament Melosira

15B Frustules not arranged into filaments 16

16A Frustules with a raphe in at least one valve

16B Frustules without a raphe in either valve, pseudoraphe evident

17A Frustules united in zigzag chains 17

17B Frustules not in zigzag chains Tabellaria

18A Frustules united laterally 18

18B Frustules not united laterally Fragilaria

19A Frustules united apically forming spokelike

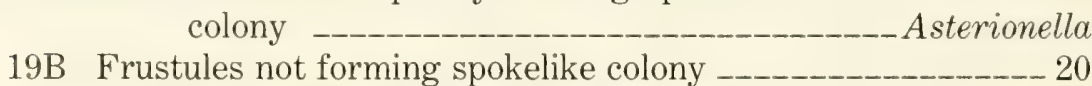

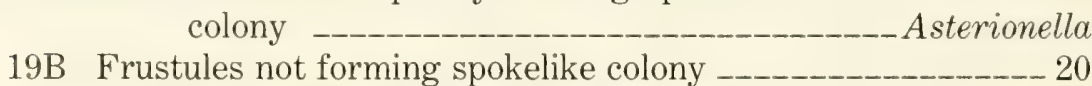
19

20A Frustules needle shaped without costae Synedra

20B Frustules with prominant costae Diatoma 
21A Frustules sigmoid or " $\mathrm{S}$ " shaped Gyrosigma

21B Frustules not sigmoid

$22 \mathrm{~A}$ Frustules longitudinally symmetrical, other than lunate in valve view

22B Frustules with raphe in both valves, longitudinally asymmetrical, lunate in valve view

23A Valves with transverse costae Epithemia

23B Valves without transverse costae

24A Raphe a smooth curve with well defined central and polar nodules Cymbella

24B Raphe not a smooth curve, gibbose with marginal central nodule Amphora

$25 \mathrm{~A}$ Frustules with raphe in both valves $-27$

25B Frustules with pseudoraphe in one valve and raphe in other valve 26

26A Frustules wedge-shaped in girdle view and cuneate in valve view Rhoicosphenia

26B Frustules shaped otherwise Achnanthes

27A Raphe extended length of valve; polar nodules evident; central nodules lacking Eunotia

27B Raphe restricted to polar regions 28

$28 \mathrm{~A}$ Raphe located in a canal Nitzschia

28B Raphe not located in a canal

29A Frustules with symmetrical valves 30

29B. Frustules with valves longitudinally symmetrical but transversely asymmetrical Gomphonema

$30 \mathrm{~A}$ Valves with transverse costae Pinnularia

30B Valves with transverse punctae Navicula

31A Cells solitary

31B Cells colonial or grouped 32

$32 \mathrm{~A}$ Cells enclosed in conical to cylindrical lorica; joined lorica have treelike appearance 
32B Cells and lorica without treelike ap-

pearance 33

33A Colony discoid, one cell in thickness; cells in

concentric rings

Pediastrum

33B Colony not discoid

$34 \mathrm{~A}$ Colonies spherical or globose _-__-___-_ 40

34B Colonies not spherical 35

$35 \mathrm{~A}$ Colony with elongate cells radiating from common center Actinastrum

35B Colony with cells not radiating from common center 36

36 A Colony with (generally) four to eight cells positioned in linear series

Scenedesmus

36B Colony with cells not in linear series 37

$37 \mathrm{~A}$ Colony with arcuate to lunate cells with apices acutely pointed; convex faces of cells apposed

Selenastrum

37B Colony with spherical to broadly ellipsoidal cells 38

$38 \mathrm{~A}$ Cells without spines or setae Crucigenia

38B Cells with spines or setae 39

39A Cells quadrate, closely apposed; free face of each cell with one or more spines Tetrastrum

39B Cells quadrate and united; free face of each cell with two to seven long delicate setae Micractinium

40A Colony with biflagellated cells Pandorina

40B Colony with nonflagellated cells

41A Cells lunate to sickle shaped 41

41B Cells spherical or nearly so Kirchneriella

$42 \mathrm{~A}$ Cells borne terminally on dichotomously branched threads _-_Dictyosphaerium

42B Cells not on dichotomously branched threads 43

$43 \mathrm{~A}$ Colony a hollow sphere 42

43B Colony not a hollow sphere Coelastrum

44A Colony surrounded by partially gelatinized and greatly expanded parent cell wall Oocystis 
44B Colony with cells equidistant and

toward periphery

Sphaerocystis

45A Cells with median constriction dividing cell

into two distinct halves

Cosmarium

45B Cells without pronounced median constric-

tion $-46$

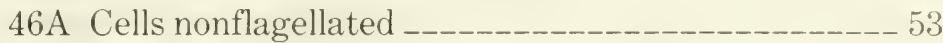

46B Cells flagellated _-_-_-_-_-_-_-_-_-_-_-_-_-_ 47

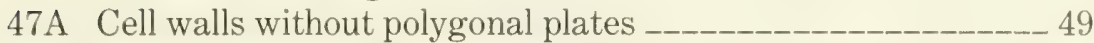

47B Cell walls with polygonal plates ___________________-__-__-__ 48

$48 \mathrm{~A}$ Cells walls of thick plates with distinct sutures _-__-__-_-__-__-__-_ Peridinium

48B Cells walls with faintly distinct plates and sutures

Glenodinium

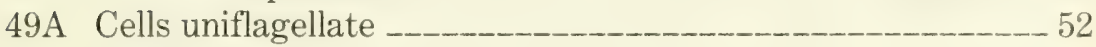

49B Cells biflagellate _-_-_-_-_-_-_-_-_-_-_-_-_-_-_-_-_-_ 50

$50 \mathrm{~A}$ Cells with two flagella of equal

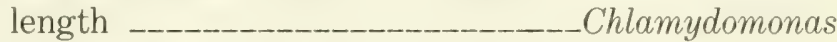

$50 \mathrm{~B}$ Cells with two flagella of unequal

length

$51 \mathrm{~A}$ Cells with single chromatophore Chroomonas

51B Cells with 2 large chromatophores Cryptomonas

$52 \mathrm{~A}$ Cells surrounded by distinet lorica_____Trachelomonas

$52 \mathrm{~B}$ Cells without lorica; fusiform to acicular shaped; posterior end more or less pointed

Euglena

$53 \mathrm{~A}$ Cells acicular to fusiform with ends tapering

into long spines

Schroederia

$53 \mathrm{~B}$ Cells without ends tapering into long spines _-_____-__-_ 54

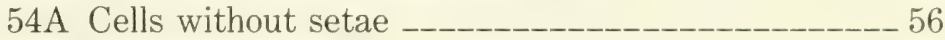

54B Cells with setae _-_-_-_-_-_-_-_-_-_-_-_-_-_-_- 55

$55 \mathrm{~A}$ Cells with subpolar or both subpolar and

equatorial long setae

Chodatella

55B Cells with multiple peripheral long delicate

setae Golenkinia

56A Cells long, slender, and tapered at both ends Ankistrodesmus

$56 \mathrm{~B}$ Cells flattened or isodiametric, triangular, quadrangular, or polygonal Tetraedron 


\section{DESCRIPTION OF THE GENERA}

Division Chlorophyta

Class Chlorophyceae

Order Chlorococcales

Family Scenedesmaceae

GENUS ACTINASTRUM Lagerheim, 1882 (fig. 1)

\section{MORPHOLOGY}

Cells are ovoid, oblong, or club shaped and radiate from a common center. Cell diameter ranges from about 1 to $6 \mu \mathrm{m}$, and cell length varies from about 10 to $35 \mu \mathrm{m}$. Chromatophores are parietal. Coenobia generally contain 4,8 , or 16 cells.

\section{REPRODUCTION}

The protoplast is divided into 4, 8 , or 16 autospores by transverse and longitudinal division. The daughter cells, joined in fasciculate bundles, are released following rupture of the parent-cell wall. Following release, the cells separate outwardly from the point where the cells touch.

\section{OCCURRENCE}

Actinastrum is widely distributed in the euplankton.

\section{ENVIRONMENTAL CONDITIONS}

\begin{tabular}{|c|c|c|c|c|}
\hline \multirow{3}{*}{$\begin{array}{l}\text { Temperature_____________ degrees Celsius_- } \\
\text { pH }\end{array}$} & \multicolumn{2}{|c|}{ Range } & \multirow{2}{*}{$\begin{array}{c}\text { Mean } \\
20.8\end{array}$} & \multirow{2}{*}{$\begin{array}{c}\text { Standard } \\
\text { deviation }\end{array}$} \\
\hline & $0.0-$ & 36.0 & & \\
\hline & $5.7-$ & 9.6 & 7.8 & .6 \\
\hline Dissolved oxygen___________milligrams per liter __- & $.8-$ & 19.7 & 8.6 & 2.3 \\
\hline Specific conductance ______micromho__ & 10 & 800 & 958 & 2,210 \\
\hline Total alkalinity ______________milligrams per liter_-_ & 3 & 440 & 138 & 78 \\
\hline Total hardness _._._____ do & 6 & 800 & 253 & 250 \\
\hline Total nitrogen _____..... & $.01-$ & 17.0 & 1.80 & 1.83 \\
\hline Total phosphorus _._____ & .0 & 3.5 & .2 & .3 \\
\hline
\end{tabular}

\section{SPECIES INFORMATION}

Refer to Smith (1920) and Prescott (1962). 


$$
\text { k }
$$


Division Chlorophyta

Class Chlorophyceae

Order Chlorococcales

Family Oocystaceae

GENUS ANKISTRODESMUS Corda, 1838; emend., Ralfs, 1848 (fig. 2)

\section{MORPHOLOGY}

Cells are acicular to fusiform, straight, curved, or sigmoid. Diameter ranges from about 1 to $4 \mu \mathrm{m}$; cells length varies from 15 to $80 \mu \mathrm{m}$. Cells are generally singular but may be loosely aggregated. The single chromatophore is parietal.

\section{REPRODUCTION}

The cell divides longitudinally into 2,4 , or 8 autospores.

\section{OCCURRENCE}

Ankistrodesmus is widely distributed in the euplankton, but it rarely occurs in abundance. According to Smith (1950), aquariums and other receptacles containing water that has been standing in the laboratory for some time may contain a virtually unialgal culture of the alga. The commonly occurring species, Ankistrodesmus falcatus, is generally found in acidic water of high temperature, where there is a dense conglomeration of other algae.

ENVIRONMENTAL CONDITIONS

\begin{tabular}{|c|c|c|c|}
\hline & Range & Mean & $\begin{array}{l}\text { Standard } \\
\text { deviation }\end{array}$ \\
\hline Temperature____________egrees Celsius__ & $0.0-$ & 17.4 & 8.6 \\
\hline $\mathrm{pH}_{\text {L }}$ & $3.4-$ & 7.6 & .7 \\
\hline $\begin{array}{l}\text { Dissolved oxygen_--__-_-_-_-_milligrams per liter } \\
\text { Specific conductance }\end{array}$ & $10^{.1-50,000}$ & $\begin{array}{c}8.9 \\
857\end{array}$ & 1,881 \\
\hline Total alkalinity & $-\quad 500$ & 116 & 83 \\
\hline Total hardness & $3-2,000$ & 217 & 258 \\
\hline Total nitrogen & $.00-\quad 41.0$ & 1.54 & 1.80 \\
\hline Total phosphorus ___ & $.0-$ & .2 & .3 \\
\hline
\end{tabular}

SPECIES INFORMATION

Refer to Brunnthaler (1915) and Prescott (1962). 


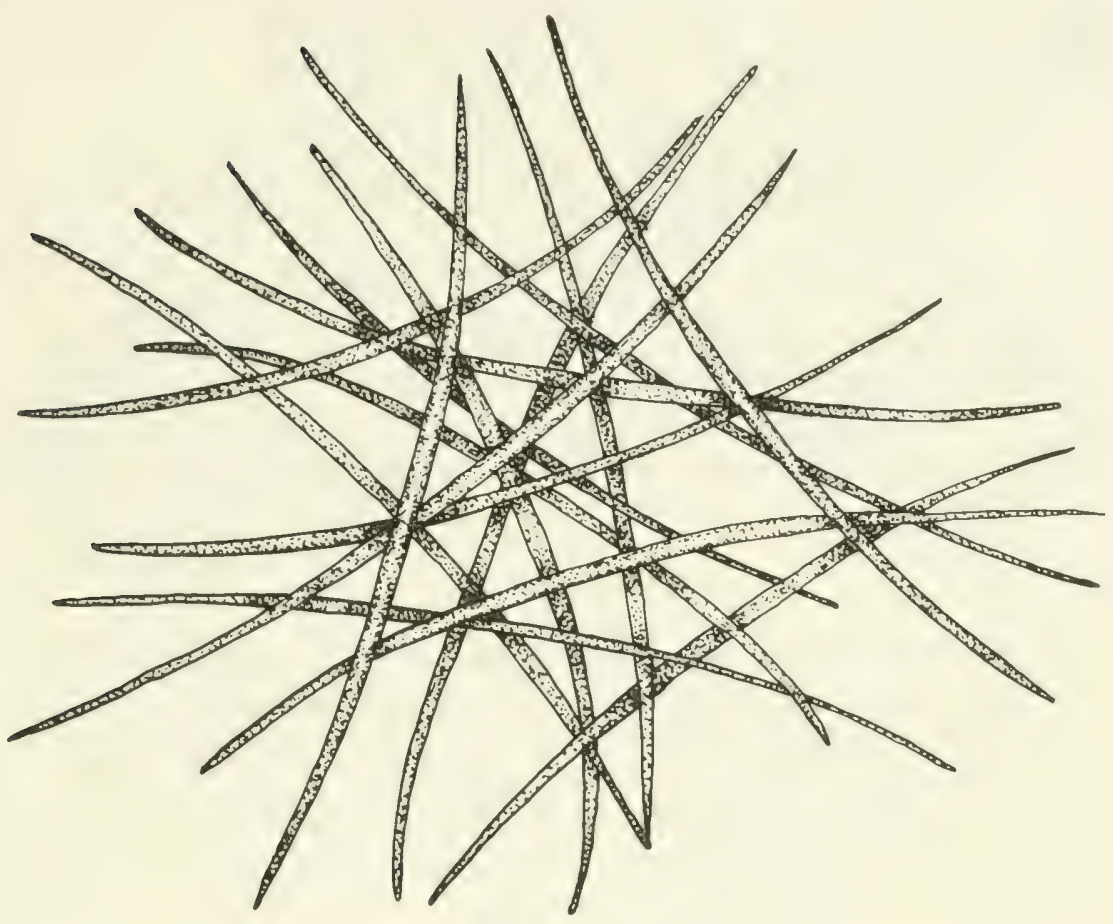

Figure 2.-Drawing of Ankistrodesmus. 
Division Chlorophyta

Class Chlorophyceae

Order Volvocales

Family Chlamydomonadaceae

GENUS CHLAMYDOMONAS Ehrenberg, 1833 (fig. 3)

\section{MORPHOLOGY}

Actively motile solitary cells are ovoid, spherical, fusiform, or ellipsoidal and range from 3 to $10 \mu \mathrm{m}$ in diameter. Two equal-lengthed flagella are located at the anterior end. Cell contains a single, cupshaped chromatophore and contractile vacuoles. Eyespot may or may not be present.

\section{REPRODUCTION}

The alga reproduces both asexually and sexually. Asexual reproduction is by longitudinal division into 2,4 , or 8 daughter cells, which are enveloped in an amorphous gelatinous wall. Continued division results in the palmella stage. Cells develop flagella and escape through the parent-cell wall. Species may be homothallic or heterothallic, and gametic union may be isogamous, anisogamous, oogamous.

\section{OCCURRENCE}

The alga occurs commonly in the euplankton and tychoplankton as solitary, free-swimming cells. It has a widespread distribution, but generally it is found in calm or very slowly moving waters.

ENVIRONMENTAL CONDITIONS

\begin{tabular}{|c|c|c|c|}
\hline & Range & Mean & $\begin{array}{l}\text { Standard } \\
\text { deviation }\end{array}$ \\
\hline degrees Celsius__ & $0.0-$ & 16.8 & 8.9 \\
\hline $\mathrm{pH}$ & $4.1-$ & 7.7 & .7 \\
\hline milligrams per liter & $1-$ & 9.0 & 2.6 \\
\hline Specific conductance & $10^{-49,800}$ & 1,185 & 3,250 \\
\hline Total alkalinity & $-\quad 500$ & 132 & 85 \\
\hline Total hardness & $-2,000$ & 252 & 289 \\
\hline Total nitrogen & $.00-\quad 26.0$ & 1.65 & 1.86 \\
\hline Total phosphorus & $.0-$ & .2 & .4 \\
\hline
\end{tabular}

\section{SPECIES INFORMATION}

Refer to Pascher (1927), Gerloff (1940), and Prescott (1962). 


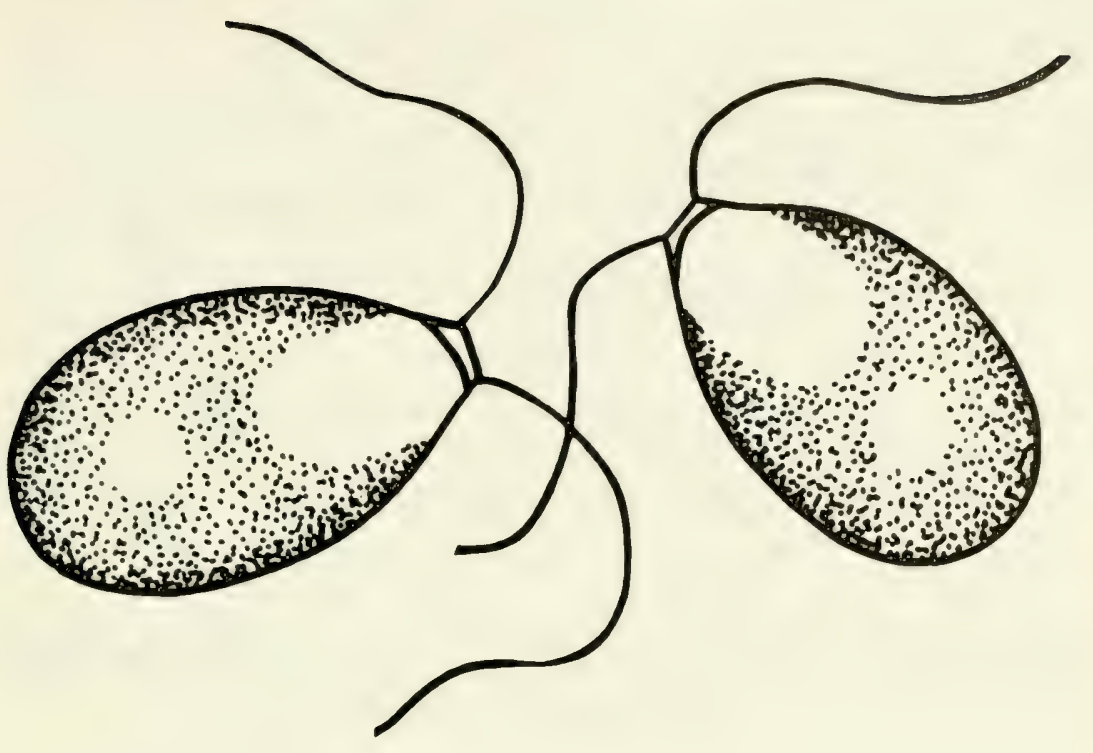

Figure 3.-Drawing of Chlamydomonas. 
Division Chlorophyta

Class Chlorophyceae

Order Chlorococcales

Family Oocystaceae

GENUS CHODATELLA Lemmermann, 1898 (fig. 4)

Generic synonym. - Lagerheimia Chodat, 1895.

\section{MORPHOLOGY}

Solitary cells are citriform, ellipsoidal, subcylindrical, or subspherical and contain long setae that are subpolar, or subpolar and equatorial, in insertion. One to four laminate to discoid chromatophores are present.

\section{REPRODUCTION}

Cells divide into 2,4 , or 8 autospores, which are released simultaneously from the parent-cell wall. Setae develop after release.

\section{OCCURRENCE}

Solitary, free-floating cells are found commonly in the euplankton.

ENVIRONMENTAL CONDITIONS

\begin{tabular}{|c|c|c|c|}
\hline & Range & Mean & $\begin{array}{l}\text { Standard } \\
\text { deviation }\end{array}$ \\
\hline _-_-_-_-_-__degrees Celsius___ & $0.0-$ & 19.0 & 8.2 \\
\hline $\mathrm{pH}_{-}$ & $5.6-$ & 7.8 & .6 \\
\hline Dissolved oxygen_____________milligrams per liter___ & $.1-$ & 9.0 & 2.4 \\
\hline Specific conductance ___ & $11-21,500$ & 972 & 1,700 \\
\hline Total alkalinity _____________milligrams per liter & -440 & 129 & 78 \\
\hline 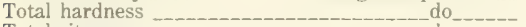 & $-1,800$ & 249 & 254 \\
\hline 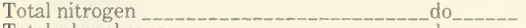 & $.05-\quad 26.0$ & 1.66 & 1.92 \\
\hline Total phosphorus ______________________ & $.0-$ & .2 & .4 \\
\hline
\end{tabular}

\section{SPECIES INFORMATION}

Refer to Smith $(1920,1926)$ and Prescott (1962). 


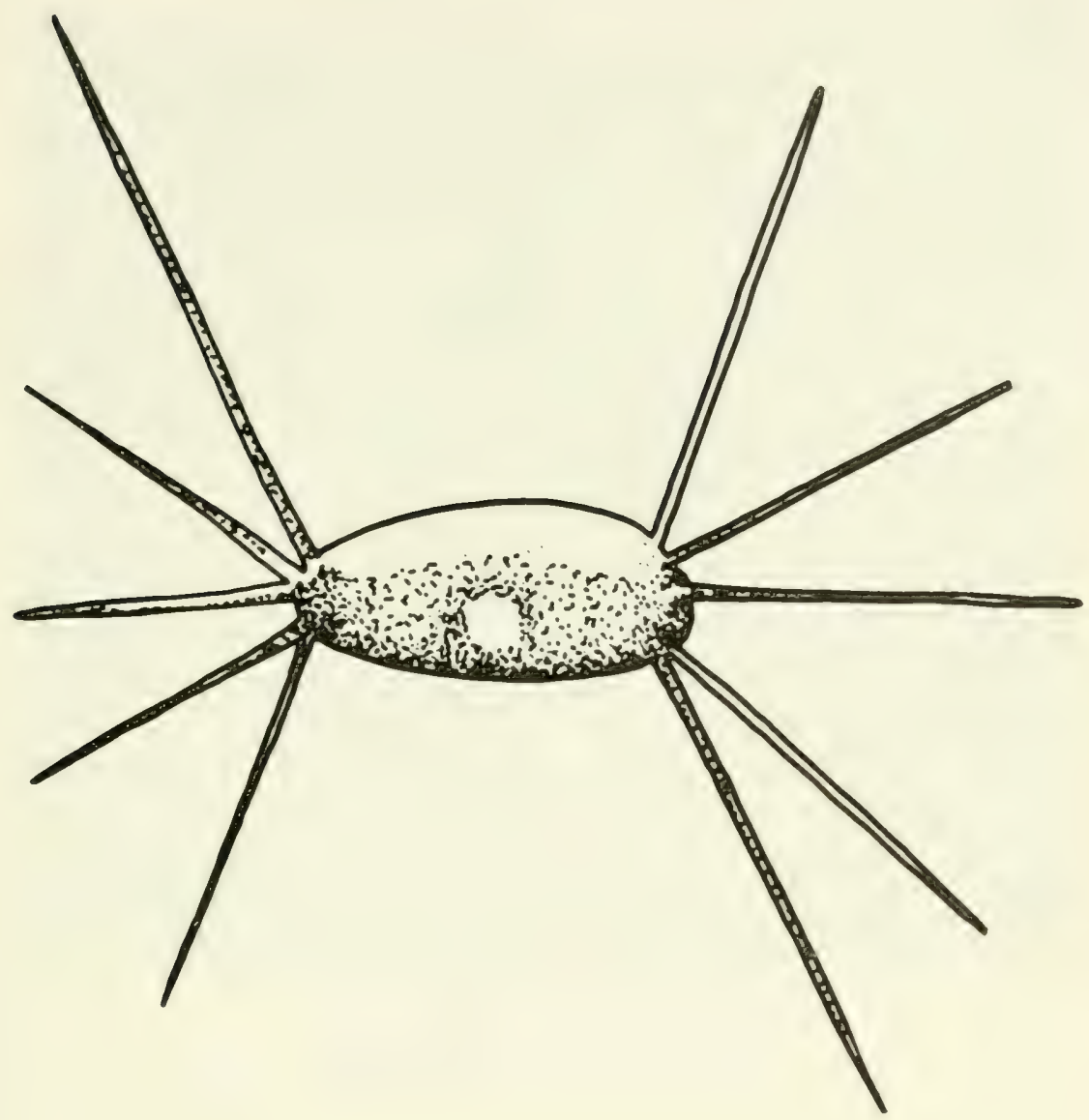

Figure 4.-Drawing of Chodatella. 
Division Chlorophyta

Class Chlorophyceae

Order Chlorococcales

Family Coelastraceae

GENUS COELASTRUM Nägeli, 1849 (fig. 5)

\section{MORPHOLOGY}

Cells are spherical, ovoid, or pyramidal and range from 3 to $25 \mu \mathrm{m}$ in diameter. Chromatophores are cup shaped to diffuse. Coenobia generally are hollow spheres consisting of $4,8,16,32,64$, or 128 cells connected by processes of varying length. Sheath is very delicate.

\section{REPRODUCTION}

One or more cells in the colony divides into $4,8,16,32,64$, or 128 autospores that remain united. The newly formed colony is released by bipartition or quadripartition of the parent-cell wall (Crow, 1925). Occasionally, a cell develops into an aplanospore, which is released prior to division into a new colony.

\section{OCCURRENCE}

The genus is widely distributed in slowly moving waters. It is an insignificant component of algal communities indicating eutrophic conditions. It often is found sparingly intermingled with other algae in pools and ditches (Smith, 1950).

\section{ENVIRONMENTAL CONDITIONS}

\begin{tabular}{|c|c|c|c|}
\hline & Range & Mean & $\begin{array}{l}\text { Standard } \\
\text { deviation }\end{array}$ \\
\hline ___-__degrees Celsius___ & $0.0-$ & 22.2 & 6.0 \\
\hline $\mathrm{pH}$ & $4.2-$ & 7.7 & .6 \\
\hline milligrams per liter_-_ & $.4-$ & 8.1 & 2.2 \\
\hline Specific conductance & $10^{.4}-35,500$ & 808 & 1,660 \\
\hline Total alkalinity & $-\quad 390$ & 120 & 71 \\
\hline Total hardness & $-1,400$ & 212 & 200 \\
\hline Total nitrogen & $.07-\quad 19.0$ & 1.67 & 1.90 \\
\hline Total phosphorus & $.0-$ & .2 & .3 \\
\hline
\end{tabular}

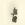

SPECIES INFORMATION

Refer to Ducellier (1915), Brunnthaler (1915), and Prescott (1962). 


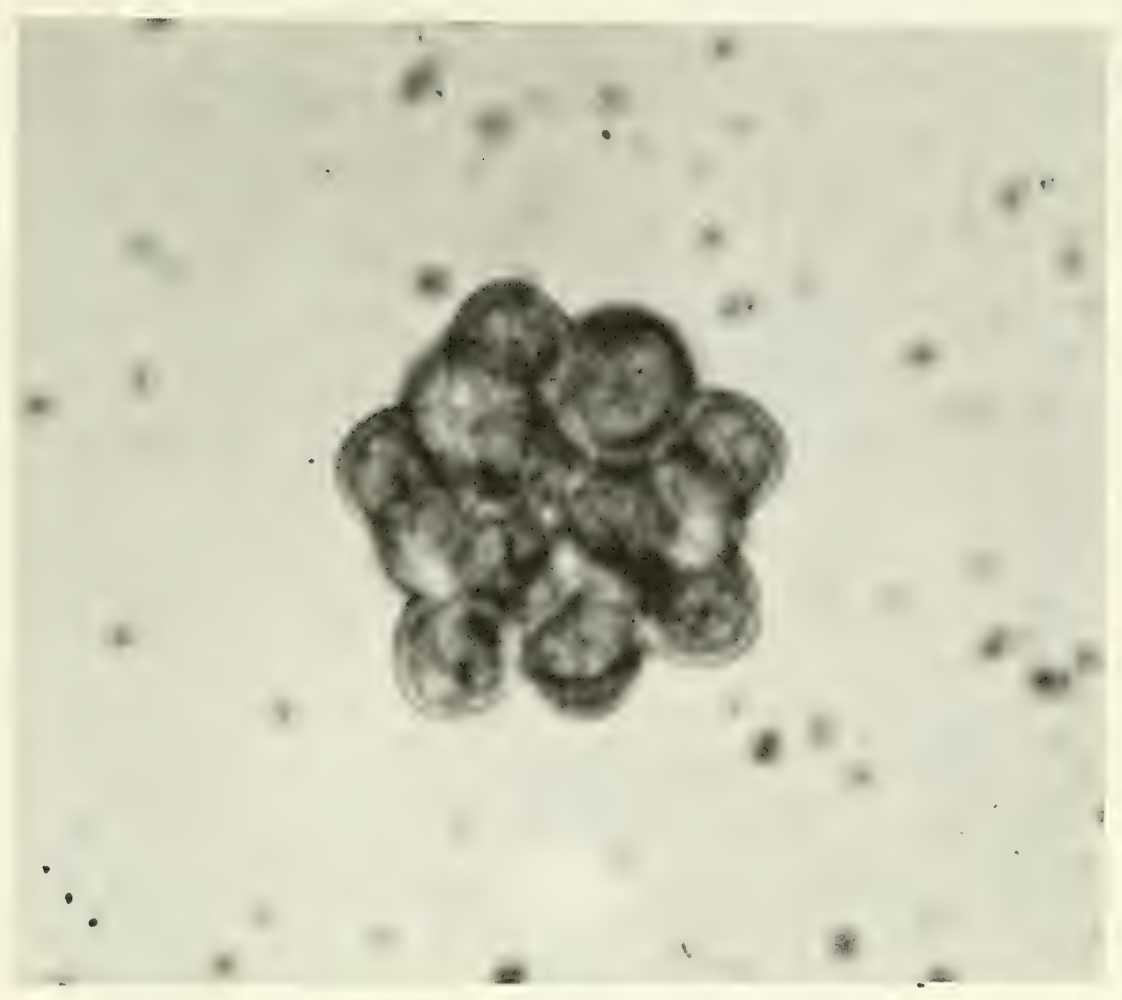

FigURE 5,-Photomicrograph of Coelastrum. 
Division Chlorophyta.

Class Chlorophyceae

Order Zygnematales

Family Desmidiaceae

GENUS COSMARIUM Corda, 1834 (fig. 6)

\section{MORPHOLOGY}

Cells are variable in size, ranging from 9 to $100 \mu \mathrm{m}$ in diameter and generally are longer than wide. Semicells are elliptical, semicircular, subquadrate, or pyramidal. The apex is rounded, truncate, or subtruncate, without an apical incision. A single, axial chromatophore is located in each semicell. The genus is solitary.

\section{REPRODUCTION}

During sexual reproduction, the protoplasts of 2 conjugating cells emerge at each isthmus, unite, and form a zygote. Each zygote develops into 2 daughter cells, each of which develops a cell wall before being released by rupture of the zygotic wall.

\section{OCCURRENCE}

There are many species in the genus, which has widespread distribution.

ENVIRONMENTAL CONDITIONS

\begin{tabular}{|c|c|c|c|}
\hline & Range & Mean & $\begin{array}{l}\text { Standard } \\
\text { deviation }\end{array}$ \\
\hline $\begin{array}{l}\text { Temperature________degrees Celsius__- } \\
\mathrm{pH}\end{array}$ & $\begin{array}{ll}0.0- & 34.0 \\
5.2- & 10.0\end{array}$ & $\begin{array}{r}21.0 \\
7.6\end{array}$ & 7.2 \\
\hline Dissolved oxygen_______ milligrams per liter & $.7-$ & 8.3 & 2.3 \\
\hline Specific conductance _._._____ micromho__ & $10-18,000$ & 529 & 1,150 \\
\hline Total alkalinity ________ milligrams per liter__ & $2-430$ & 89 & 70 \\
\hline Total hardness _._. & $6-1,200$ & 146 & 153 \\
\hline Total nitrogen _._. & $.09-$ & 1.31 & 2.11 \\
\hline Total phosphorus ___ do & $.0-$ & .1 & .2 \\
\hline
\end{tabular}

SPECIES INFORMATION

Refer to West and West $(1905,1908,1912)$. 


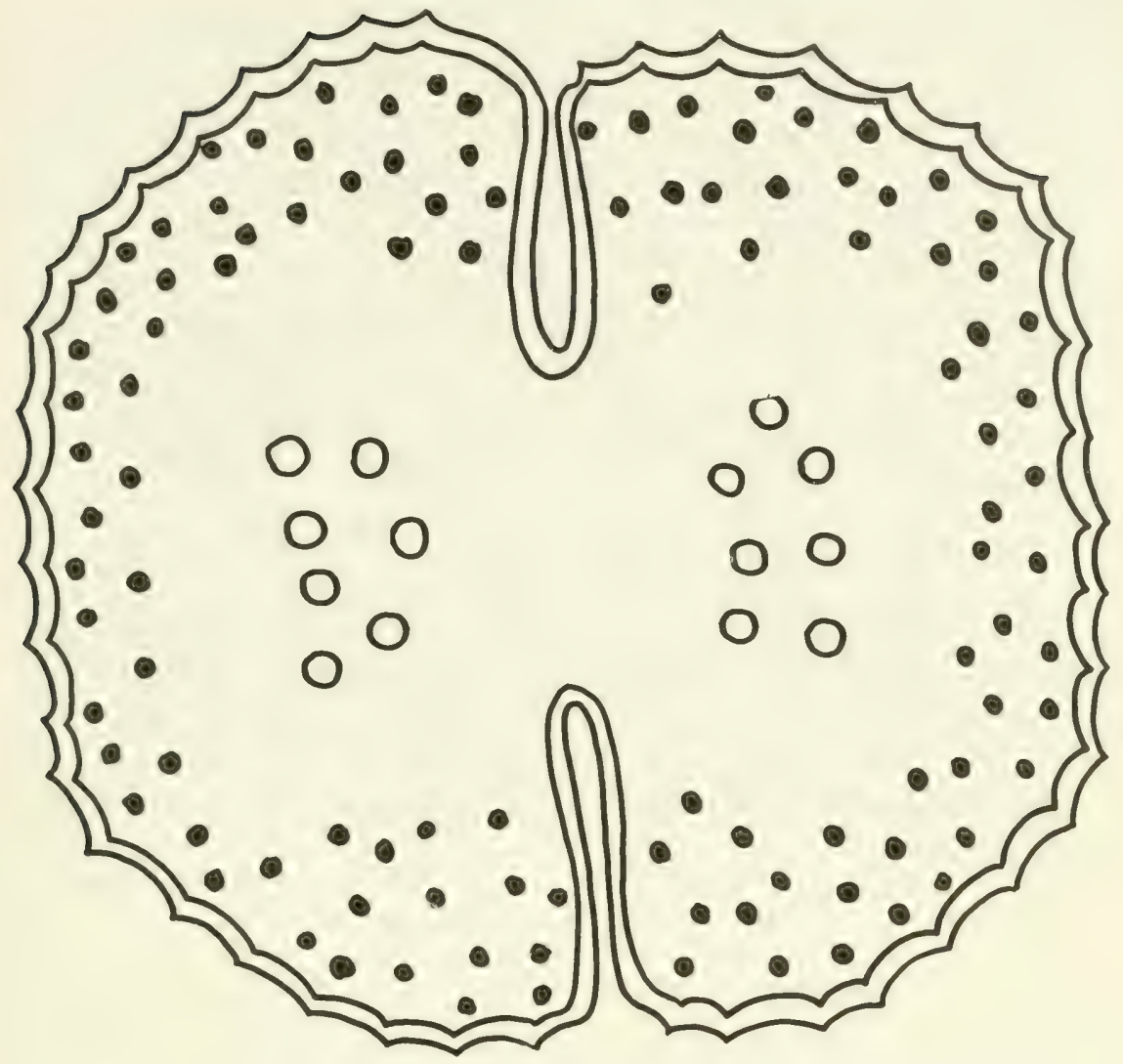

Figure 6.-Drawing of Cosmarium. 
Division Chlorophyta

Class Chlorophyceae

Order Chlorococcales

Family Scenedesmaceae

GENUS CRUCIGENIA Morren, 1830 (fig. 7)

\section{MORPHOLOGY}

Cells, 4-10 $\mu \mathrm{m}$ in diameter, are elliptical, triangular, trapezoidal, or semicircular in surface view. One to 4 cup-shaped chromatophores are situated parietally in each cell. Cells are joined quadrately to form a 4-celled coenobia. Several coenobia may be enclosed in a gelatinous envelope.

\section{REPRODUCTION}

The protoplast divides into 4 autospores that remain quadrately apposed.

\section{OCCURRENCE}

Free-floating colonies occur commonly in the euplankton. It is widely distributed.

ENVIRONMENTAL CONDITIONS

\begin{tabular}{|c|c|c|c|}
\hline & Range & Mean & $\begin{array}{l}\text { Standard } \\
\text { deviation }\end{array}$ \\
\hline _degrees Celsius__ & $0.0-$ & 19.6 & 8.0 \\
\hline $\mathrm{pH}_{-}$ & $4.7-$ & 7.6 & .7 \\
\hline milligrams per liter & $.5-$ & 8.5 & 2.4 \\
\hline Specific conductance & $10-45,500$ & 716 & 1,540 \\
\hline Total alkalinity ____ milligrams per liter & -440 & 116 & 85 \\
\hline Total hardness & $-1,700$ & 192 & 196 \\
\hline Total nitrogen & $.03-\quad 20.0$ & 1.46 & 1.56 \\
\hline Total phosphorus & $.0-$ & .2 & .3 \\
\hline
\end{tabular}

SPECIES INFORMATION

Refer to Smith $(1920,1926)$ and Prescott $(1962)$. 


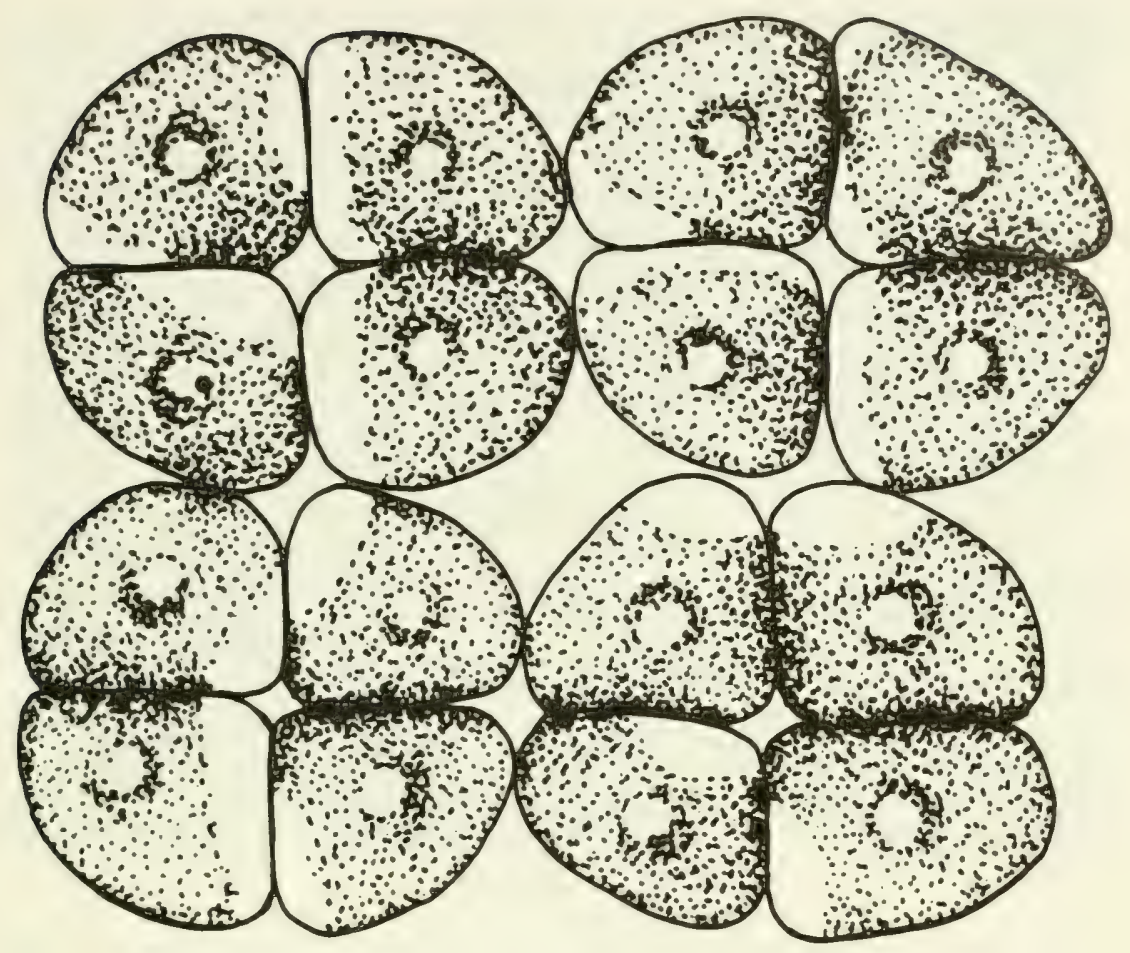

Figure 7.-Drawing of Crucigenia. 


\section{Division Chlorophyta \\ Class Chlorophyceae \\ Order Chlorococcales \\ Family Oocystaceae \\ GENUS DICTYOSPHAERIUM Nägeli, 1849 (fig. 8) \\ MORPHOLOGY}

Cells are spherical, ovoid, ellipsoidal, or reniform and range from 3 to $10 \mu \mathrm{m}$ in diameter. Each cell contains a single, cup-shaped, parietal chromatophore. Cells are connected by branching threads. Colony is embedded in a copious, homogeneous, gelatinous sheath.

\section{REPRODUCTION}

Antherozoids (generally 16 or 32) from a male colony swarm around one of 2 eggs released by a female colony. An antherozoid and an egg become laterally fused to form a zygote. Division of the zygote forms a daughter colony. Asexual reproduction of a cell into 2 to 4 autospores precedes the movement of the daughter cells to the tips of segments formed by the partial splitting of the parent-cell wall.

\section{OCCURRENCE}

The alga is of widespread distribution. It is found most often in soft to semihard waters.

\section{ENVIRONMENTAL CONDITIONS}

\begin{tabular}{|c|c|c|c|}
\hline & Range & Mean & $\begin{array}{l}\text { Standard } \\
\text { deviation }\end{array}$ \\
\hline _____egrees Celsius___ & $0.0-$ & 20.0 & 7.6 \\
\hline 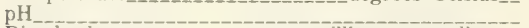 & $4.6-$ & 7.6 & 7 \\
\hline Dissolved oxygen______ milligrams per liter & $1-$ & 8.5 & 2.3 \\
\hline Specific conductance _....... micromho & $10-50,000$ & 814 & 1,860 \\
\hline Total alkalinity _.__ milligrams per liter & $-\quad 440$ & 112 & 80 \\
\hline Total hardness & $-1,900$ & 206 & 232 \\
\hline Total nitrogen & $.00-\quad 19.0$ & 1.49 & 1.55 \\
\hline Total phosphorus & $.0-$ & .2 & .3 \\
\hline
\end{tabular}

SPECIES INFORMATION

Refer to Tiffany (1934), Smith (1920), and Prescott (1962). 


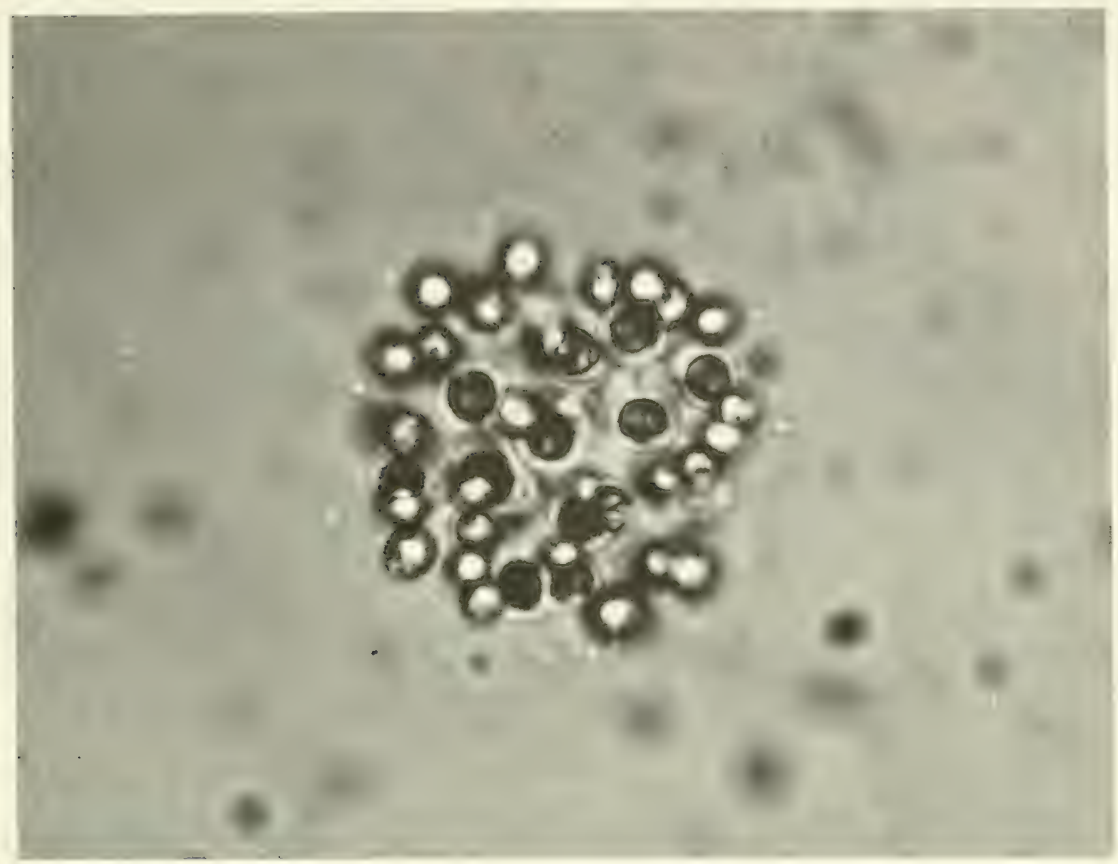

FIGURE 8. - Photomicrograph of Dictyosphaerium. 


\section{Division Chlorophyta}

Class Chlorophyceae

Order Chlorococcales

Family Micractiniaceae

GENUS GOLENKINIA Chodat, 1894 (fig. 9)

\section{MORPHOLOGY}

Solitary cells, $7-15 \mu \mathrm{m}$ in diameter, contain numerous, long, slightly tapering setae. The single chromatophore is parietal and cup shaped.

\section{REPRODUCTION}

Two, 4, or 8 autospores are formed and released by fragmentation of the parent-cell wall. Sexual reproduction is oogamous. Biflagellate antherozoids swarm around a cell containing a single egg, a part of which protrudes through the cell wall. After fusion, the zygote moves through the pore and becomes attached to the parent-cell wall.

\section{OCGURRENCE}

Golenkinia is common in the euplankton. It is present generally in shallow, slow-moving waters.

\section{ENVIRONMENTAL CONDITIONS}

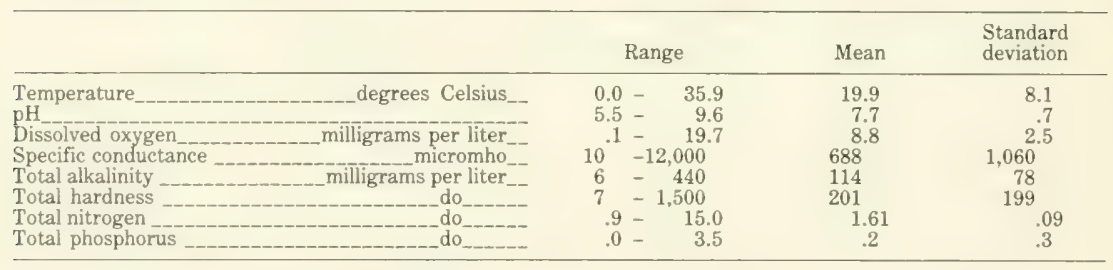

SPECIES INFORMATION

Refer to Tiffany (1934), Smith (1920), and Prescott (1962). 


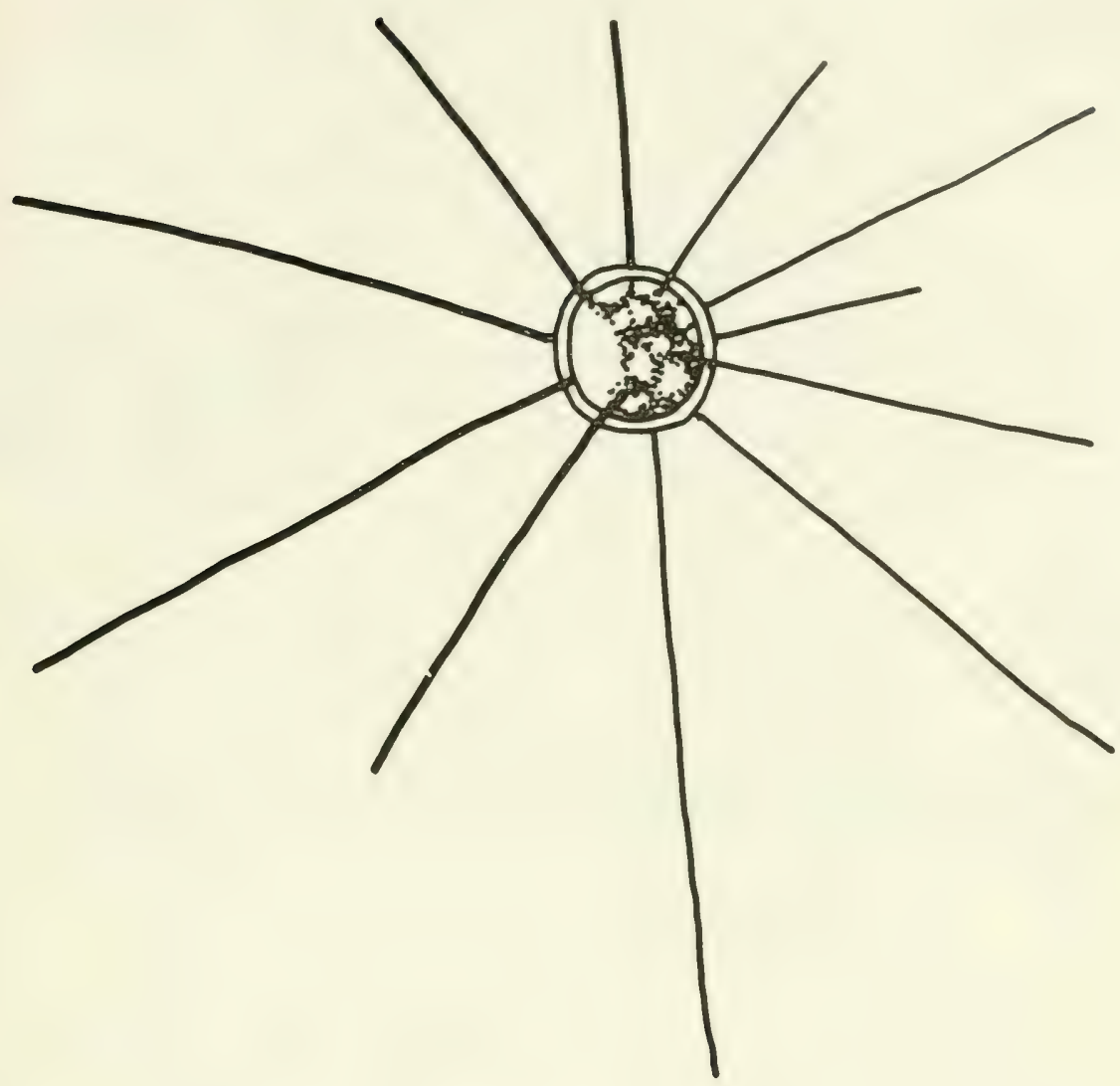

FigURE 9.-Drawing of Golenkinia. 
Division Chlorophyta

Class Chlorophyceae

Order Chlorococcales

Family Oocystaceae

GENUS KIRCHNERIELLA Schmidle, 1893 (fig. 10)

\section{MORPHOLOGY}

Cells are generally acute or lunate and attenuated. Cell apices are often in close proximity. A single chromatophore is parietal on convex side of cell or entirely fills the cells. Cells are arranged loosely in groups of 4 or 8 within a wide gelatinous envelope. Colony may be as much as $250 \mu \mathrm{m}$ in diameter.

\section{REPRODUCTION}

Cellular division results in 4 to 8 autospores that separate as the parent-cell wall gelatinizes.

\section{OCCURRENCE}

The genus rarely occurs in great numbers and often is found intermingled among other algae. It generally is indicative of acidic conditions.

ENVIRONMENTAL CONDITIONS

\begin{tabular}{|c|c|c|c|}
\hline & Range & Mean & $\begin{array}{l}\text { Standard } \\
\text { deviation }\end{array}$ \\
\hline _-___-________degrees Celsius__ & $0.0-$ & 20.0 & 7.9 \\
\hline $\mathrm{pH}$ & $3.7-$ & 7.7 & .7 \\
\hline Dissolved oxygen & $1-$ & 8.6 & 2.5 \\
\hline Specific conductance & $10-48,000$ & 918 & 2,350 \\
\hline Total alkalinity & $-\quad 470$ & 119 & 80 \\
\hline Total hardness & $6-2,000$ & 218 & 239 \\
\hline Total nitrogen & $.00-\quad 21.0$ & 1.61 & 1.75 \\
\hline Total phosphorus & $.0-$ & .2 & .3 \\
\hline
\end{tabular}

SPECIES INFORMATION

Refer to West (1908), Smith (1920), and Prescott (1962). 


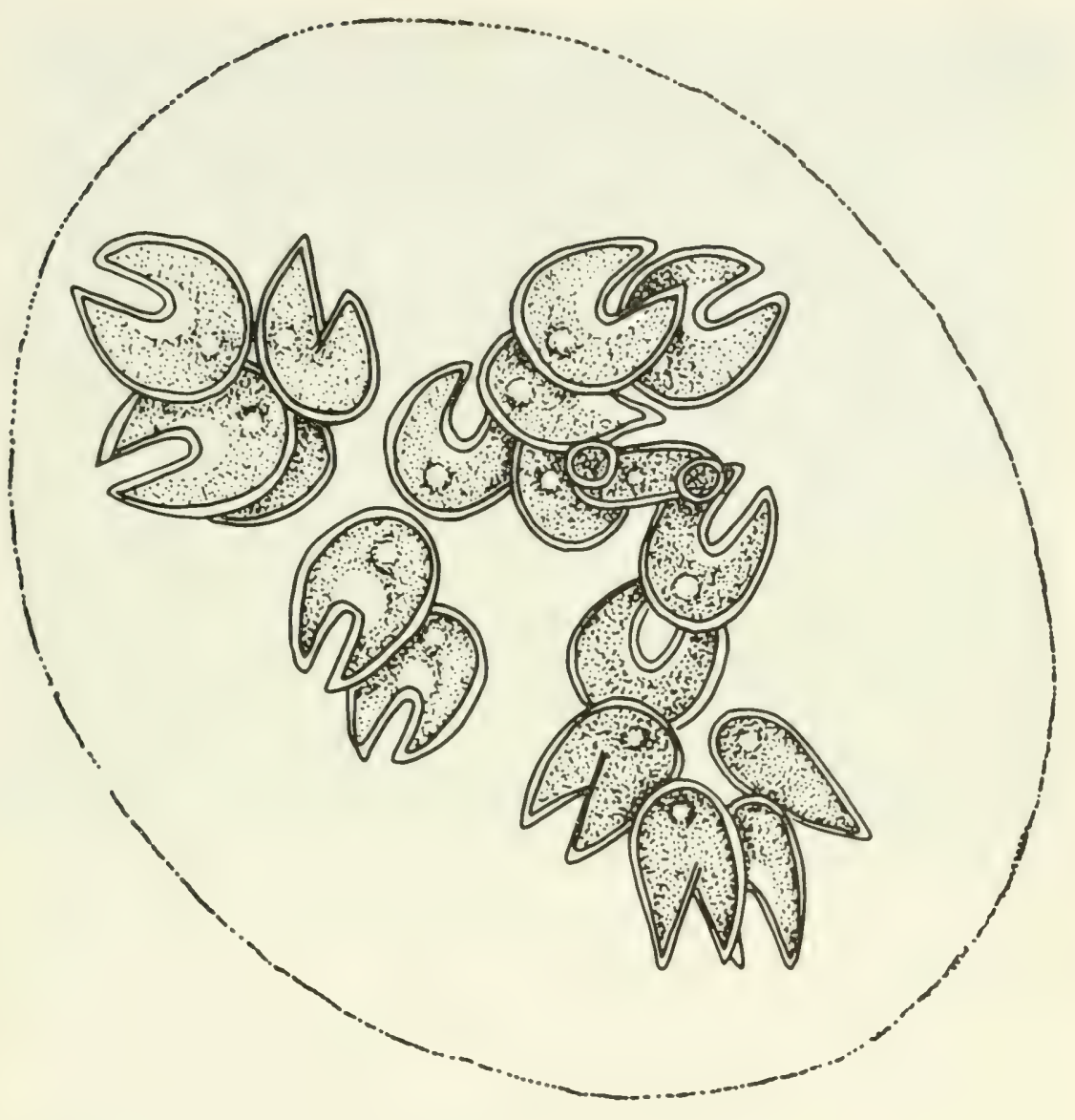

FIGURE 10.-Drawing of Kirchneriella. 


\section{Division Chlorophyta}

Class Chlorophyceae

Order Chlorococcales

Family Micractiniaceae

GENUS MICRACTINIUM Fresenius, 1858 (fig. 11)

\section{MORPHOLOGY}

Cells are spherical to broadly ellipsoidal and $4-8 \mu \mathrm{m}$ in diameter. The single, cup-shaped chromatophore is parietal. Each cell bears 1 to 7 long uniform setae. Cells generally are quadrately united in a 4-celled coenobium. Several coenobia are generally united.

\section{REPRODUCTION}

The cell divides asexually into 4 autospores, which are released when the parent-cell wall ruptures into 4 symmetrical parts. Oogamous sexual reproduction is by the union of a biflagellate antherozoid and an egg. The egg protrudes through an opening in the cell wall at the time of fertilization. Following fertilization, the zygote moves through the opening and becomes attached to the parent-cell wall.

\section{OCCURRENCE}

Free-floating colonies are common in the euplankton. It is generally indicative of soft-water conditions.

\section{ENVIRONMENTAL CONDITIONS}

\begin{tabular}{|c|c|c|c|}
\hline & Range & Mean & $\begin{array}{l}\text { Standard } \\
\text { deviation }\end{array}$ \\
\hline _-___-_ degrees Celsius___ & $0.0-$ & 19.0 & 7.9 \\
\hline $\mathrm{pH}$ & $5.9-$ & 7.8 & .6 \\
\hline Dissolved oxygen & $.1-$ & 8.9 & 2.5 \\
\hline Specific conductance _._. & $11-10,200$ & 761 & 1,150 \\
\hline Total alkalinity _._. milligrams per liter & $-\quad 426$ & 125 & 78 \\
\hline Total hardness & $-1,500$ & 215 & 206 \\
\hline _. & $.03-\quad 26.0$ & 1.97 & 2.32 \\
\hline Total phosphorus _.___._. & $.0-$ & .3 & .4 \\
\hline
\end{tabular}

\section{SPECIES INFORMATION}

Refer to Tiffany (1934), Smith (1920), and Prescott (1962). 


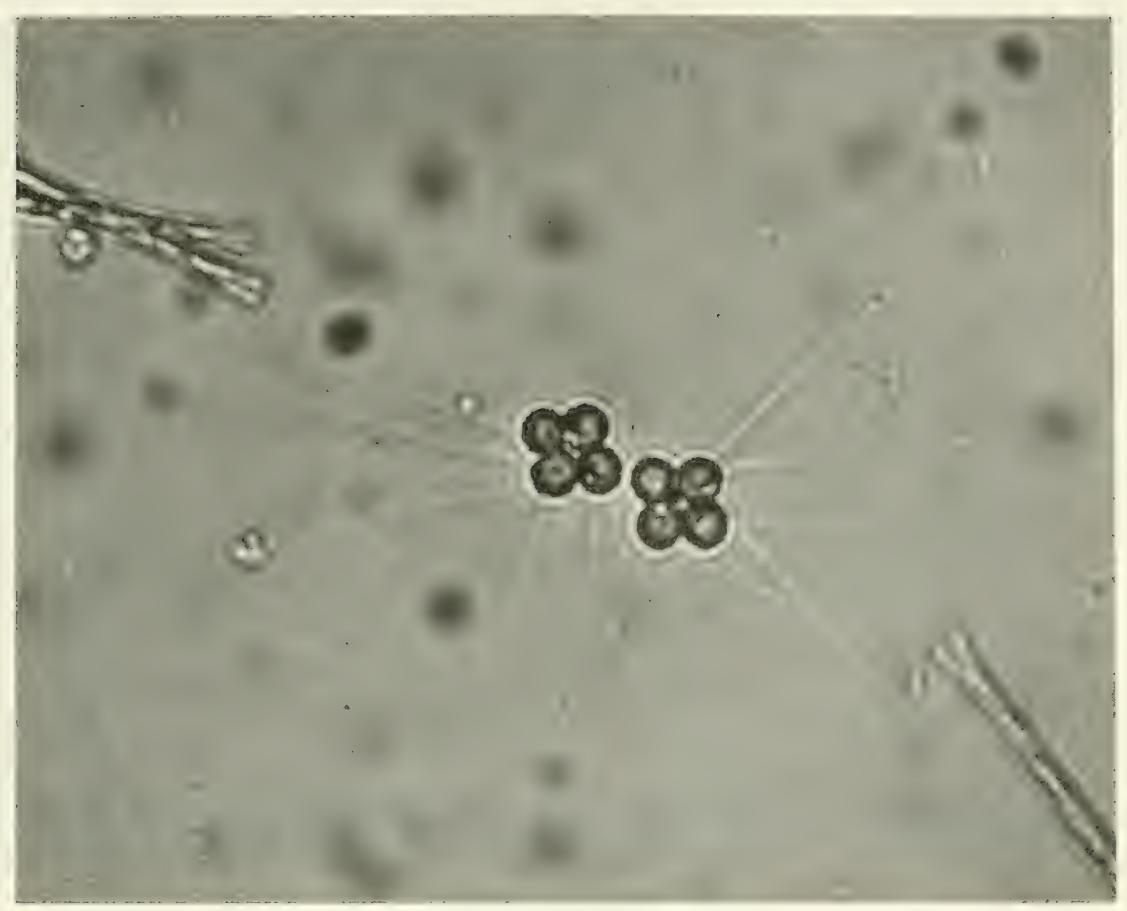

FIgURE 11.-Photomicrograph of Micractinium. 
Division Chlorophyta

Class Chlorophyceae

Order Chlorococcales

Family Oocystaceae

GENUS OOCYSTIS Nägeli, 1855 (fig. 12)

\section{MORPHOLOGY}

Cells are ovoid, ellipsoidal, or cylindrical; $7-45 \mu \mathrm{m}$ in diameter; and have smooth walls. A polar nodule may be present. The number of chromatophores varies from 1 to many. The genus may be solitary or in colonies of $2,4,8$, or 16 cells surrounded by a partially gelatinous and greatly swollen parent-cell wall.

\section{REPRODUCTION}

Reproduction is asexual into 2, 4, 8, or 16 autospores. Sister autospores remain within the greatly expanded parent-cell wall and may be accompanied by several groupings of sister autospores. New colonies are formed by the rupturing of the parent-cell wall.

\section{OCCURRENCE}

Oocystis is widely distributed in the euplankton and tychoplankton. It generally is indicative of soft water or oligotrophic water. Some species (for example, Oocystis elliptica) are commonly found in warm shallow water intermingled among other algae.

ENVIRONMENTAL CONDITIONS

\begin{tabular}{|c|c|c|c|}
\hline & Range & Mean & $\begin{array}{l}\text { Standard } \\
\text { deviation }\end{array}$ \\
\hline degrees Celsius___ & $0.0-$ & 19.6 & 8.0 \\
\hline 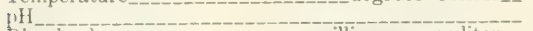 & $4.4-$ & 7.8 & .6 \\
\hline bissolved oxygen & $1.7-22.0$ & 8.7 & 2.4 \\
\hline Specific conductance _.__ micromho & $10-48,000$ & 1,120 & 2,730 \\
\hline Total alkalinity ____ milligrams per liter & -440 & 129 & 76 \\
\hline Total hardness & $7-2,000$ & 242 & 247 \\
\hline Total nitrogen & $.00-\quad 19.0$ & 1.53 & 1.59 \\
\hline Total phosphorus & $.0-$ & .2 & .3 \\
\hline
\end{tabular}

\section{SPECIES INFORMATION}

Refer to Smith (1920), Printz (1913), and Prescott (1962). 


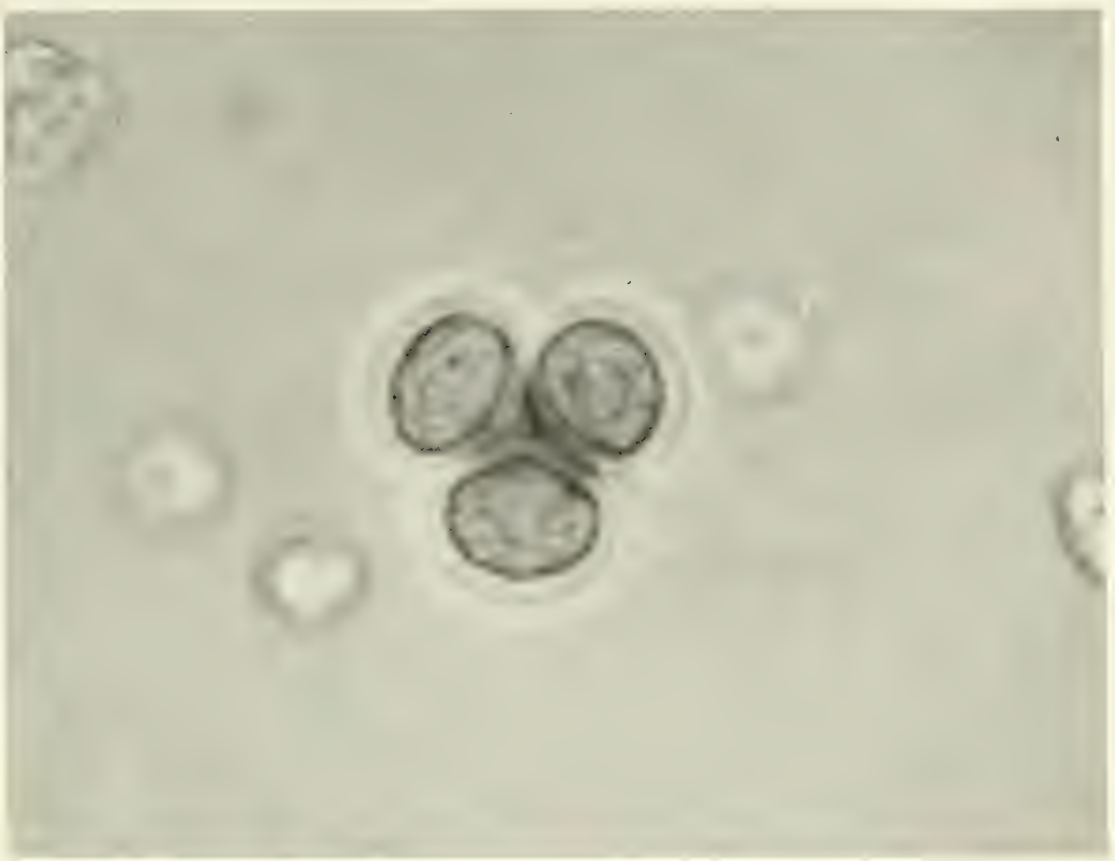

FIGURE 12.-Photomicrograph of Oocystis. 
Division Chlorophyta

Class Chlorophyceae

Order Volvocales

Family Volvocaceae

GENUS PANDORINA Bory, 1824 (fig. 13)

\section{MORPHOLOGY}

Cells are pyriform, spherical, or angular and generally $7-18 \mu \mathrm{m}$ in diameter. Each cell had 2 flagella of equal length. The single chromatophore is cup shaped. Four, 8, 16, or 32 cells are mutually comprised in the periphery of a colony and enclosed by a copious, homogeneous envelope.

\section{REPRODUCTION}

Following a state of colonial dormancy, all cells within the colony undergo simultaneous division into daughter colonies. Each cell of the daughter colony develops 2 flagella, and a new colony is formed. Sexual reproduction is anisogamous. Free-swimming male gametes fuse terminally or laterally with somewhat larger free-swimming female gametes. The quadriflagellate zygote looses its flagella and develops a cell wall. Zygote development results in biflagellate zoospores, which secrete a gelatinous envelope and divide into a new colony.

\section{OCCURRENCE}

The alga is rarely found in abundance but frequently occurs in the euplankton of hard bodies of water. It also is found frequently among dense growths of algae in shallow waters rich in nitrogenous matter (Prescott, 1962).

ENVIRONMENTAL CONDITIONS

\begin{tabular}{|c|c|c|c|}
\hline & Range & Mean & $\begin{array}{l}\text { Standard } \\
\text { deviation }\end{array}$ \\
\hline Temperature & $0.0-33.0$ & 22.1 & 6.9 \\
\hline $\begin{array}{l}\text { Dissolved oxygen } \\
\text { milligrams per liter }\end{array}$ & $\begin{array}{r}5.2- \\
1.3-\end{array}$ & 7.9 & 24 \\
\hline Specific conductance & $11-11,800$ & 612 & $993^{2.4}$ \\
\hline Total alkalinity & $\begin{array}{l}11,000 \\
-\quad 390\end{array}$ & 117 & 78 \\
\hline Total hardness & $6-1,700$ & 181 & 175 \\
\hline Total nitrogen & $.01-\quad 13.0$ & 1.4 & 1.4 \\
\hline Total phosphorus & $.0-$ & .2 & .3 \\
\hline
\end{tabular}

SPECIES INFORMATION

Refer to Smith $(1920,1931)$ and Prescott (1962). 


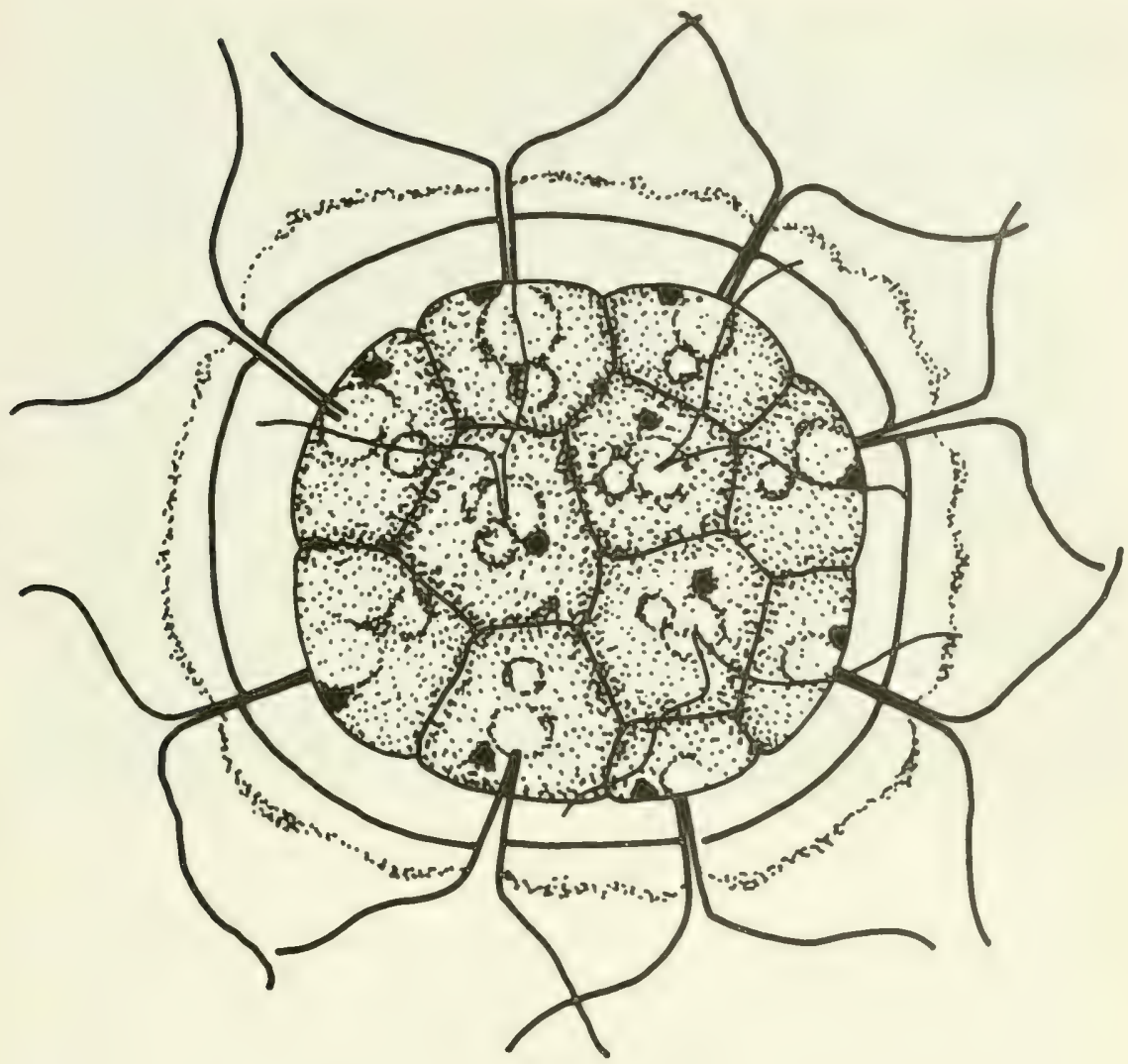

Figure 13. - Drawing of Pandorina. 


\section{Division Chlorophyta}

Class Chlorophyceae

Order Chlorococcales

Family Hydrodictyaceae

GENUS PEDIASTRUM Meyen, 1829 (fig. 14)

\section{MORPHOLOGY}

Cells are coenocytic with smooth or rough walls. Peripheral cells are shaped differently from interior cells and have 1 or 2 processes. Chromatophores are discoid to diffuse. Coenobia are plate shaped and consist of $4,8,16,32,64,128$, or 256 cells and may be as much as 450 $\mu \mathrm{m}$ in diameter.

\section{REPRODUCTION}

Biflagellate zoospores formed by several cells in the colony are contained in a vesicule of the parent-cell wall. The vesicule remains until the new colony is formed and released. Isogamous sexual reproduction is by a fusion of spindle-shaped biflagellate gametes formed like the zoospores.

\section{OCCURRENCE}

The genus is widely distributed in the euplankton and tychoplankton of all types of waters. Some species are indicative of particular environmental conditions; for example, Pediastrum simplex is indicative of oligotrophic waters, whereas Pediastrum duplex or Pediastrum Boryanum are indicative of eutrophic waters. The genus can occur in great numbers.

ENVIRONMENTAL CONDITIONS

\begin{tabular}{|c|c|c|c|}
\hline & Range & Mean & $\begin{array}{l}\text { Standard } \\
\text { deviation }\end{array}$ \\
\hline _ & $0.0-$ & 20.7 & 7.2 \\
\hline $\mathrm{pH}$ & $4.9-$ & 7.7 & .6 \\
\hline Dissolved oxygen______._. milligrams per liter & $1.1-$ & 8.4 & 2.3 \\
\hline Specific conductance _. & $30-14,000$ & 616 & 841 \\
\hline Total alkalinity & -440 & 119 & 74 \\
\hline Total hardness & $5-1,400$ & 189 & 157 \\
\hline Total nitrogen & $.00-\quad 24.0$ & 1.6 & 2.0 \\
\hline Total phosphorus & $0-$ & .2 & .4 \\
\hline
\end{tabular}

\section{SPECIES INFORMATION}

Refer to Brunnthaler (1915), Bigeard (1933), Harper (1916, 1918), and Prescott (1962). 


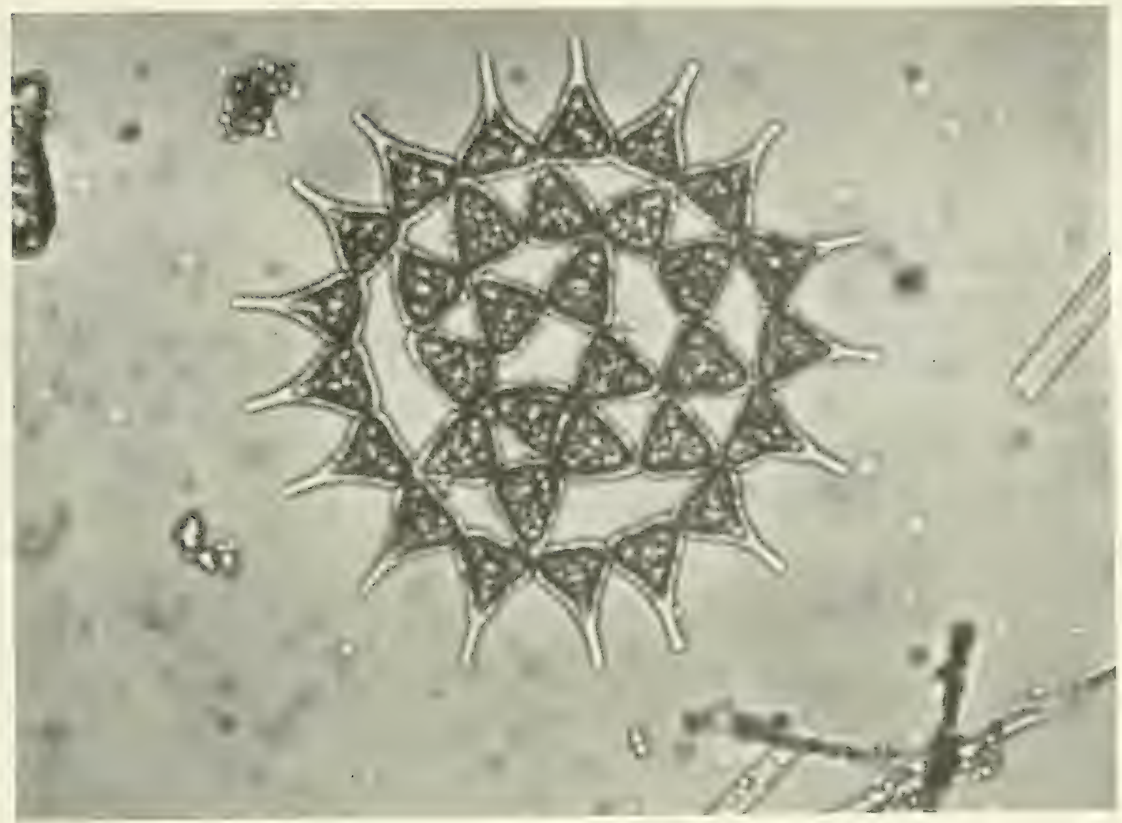

FiguRE 14.-Photomicrograph of Pediastrum. 


\section{Division Chlorophyta}

Class Chlorophyceae

Order Chlorococcales

Family Scenedesmaceae

GENUS SCENEDESMUS Meyen, 1829 (fig. 15)

\section{MORPHOLOGY}

Cells are ellipsoidal, oblong, fusiform, acicular, or ovoid. The single chromatophore is parietal. Cell walls are smooth, corrugated, granulate, or spicate with or without marginal or lateral teeth or spines. Coenobia are flat and consist of 2, 4 (most commonly), or 8 cells but sometimes as many as 16 or 32 cells.

\section{REPRODUCTION}

Transverse and longitudinal divisions into $2,4,8,16$, or 32 autospores are undertaken by a parent cell. The parent-cell wall splits longitudinally, releasing the daughter colony.

\section{OCCURRENCE}

The genus is widely distributed in the euplankton, tychoplankton, and periphyton. It is found in all types of waters. The commonly occurring species, Scenedesmus quadricauda, is one of the most nearly ubiquitous algal species. Great numbers, so as to color the water green, may occur in small pools.

\section{ENVIRONMENTAL CONDITIONS}

\begin{tabular}{|c|c|c|c|c|}
\hline \multirow{3}{*}{$\begin{array}{l}\text { Temperature ____________egrees Celsius } \\
\mathrm{pH}\end{array}$} & \multicolumn{2}{|c|}{ Range } & \multirow{2}{*}{$\begin{array}{r}\text { Mean } \\
18.1\end{array}$} & \multirow{2}{*}{$\begin{array}{r}\begin{array}{r}\text { Standard } \\
\text { deviation }\end{array} \\
8.4\end{array}$} \\
\hline & 0.0 & 37.0 & & \\
\hline & $3.4-$ & 10.0 & 7.6 & .7 \\
\hline Dissolved oxygen_________milligrams per liter & $.1-$ & 22.0 & 8.7 & 2.5 \\
\hline Specific conductance _._._______ micromho & $10-$ & 000 & 863 & 1.800 \\
\hline Total alkalinity____________milligrams per liter & 0 & 480 & 119 & 80 \\
\hline Total hardness_________ & 3 & 000 & 221 & 254 \\
\hline Total nitrogen & .00 & 26.0 & 1.6 & 2.0 \\
\hline Total phosphorus & .0 & 4.0 & .2 & .3 \\
\hline
\end{tabular}

\section{SPECIES INFORMATION}

Refer to Chodat (1926), Smith (1916), and Prescott (1962). 


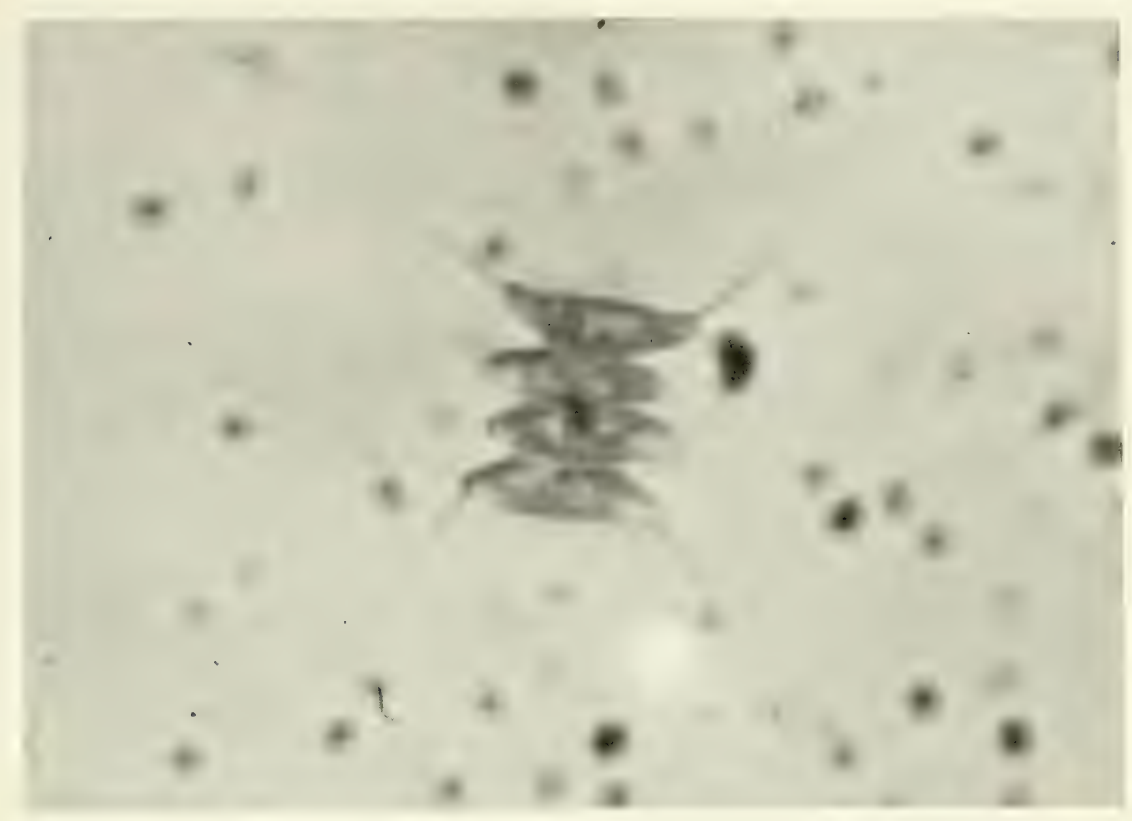

Figure 15. - Photomicrograph of Scenedesmus. 
Division Chlorophyta

Class Chlorophyceae

Order Chlorococcales

Family Characiaceae

GENUS SCHROEDERIA Lemmermann, 1899 (fig. 16)

\section{MORPHOLOGY}

Solitary cells are acicular to fusiform and are straight or slightly curved. Cell apices are tapered into setae; one may be bifurcate. Total cell length, including setae, may exceed $150 \mu \mathrm{m}$. The single chromatophore is $\mathrm{H}$-shaped. Eyespot may or may not be present.

\section{REPRODUCTION}

Biflagellate zoospores (4 or 8) form within the cell and are released by transverse splitting of the parent-cell wall. The zoospore loses its flagella and develops into a vegetative cell.

\section{OCCURRENCE}

The solitary, free-floating cells of the genus are found in the euplankton.

\section{ENVIRONMENTAL CONDITIONS}

\begin{tabular}{|c|c|c|c|}
\hline & Kange & Mean & $\begin{array}{l}\text { Staniard } \\
\text { deviation }\end{array}$ \\
\hline _.___________ degrees Celsius__ & $0.0-$ & 20.0 & 8.0 \\
\hline 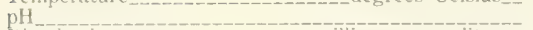 & $5.3-$ & 7.7 & .6 \\
\hline Dissolved oxygen_____ miligrams per liter & $.1-$ & 8.2 & 2.2 \\
\hline Specific conductance & $10-35,000$ & 899 & 2,145 \\
\hline Total alkalinity___ milligrams per liter & -400 & 124 & 78 \\
\hline Total hardness & $-1,700$ & 216 & 227 \\
\hline Total nitrogen & $.00-\quad 17.0$ & 1.55 & 1.81 \\
\hline Total phosphorus & $.0-$ & .2 & .4 \\
\hline
\end{tabular}

\section{SPECIES INFORMATION}

Refer to Smith $(1920,1926)$ and Prescott (1962). 
FIGURE 16. - Drawing of Schroederia. 
Division Chlorophyta

Class Chlorophyceae

Order Chlorococcales

Family Oocystaceae

GENUS SELENASTRUM Reinsch, 1867 (fig. 17)

\section{MORPHOLOGY}

Cells are arcuate to lunate with apices acutely pointed. The single chromatophore is parietal. Convex surfaces of 4,8 , or 16 cells are apposed; a colony may have as many as 100 or more cells. There is no gelatinous envelope.

\section{REPRODUCTION}

The cell contents divide into 4,8 , or 16 autospores, which generally remain opposed to one another following release from the parent-cell wall.

\section{OCCURRENCE}

Selenastrum is widely distributed in the euplankton. It is found sparingly intermingled with other free-floating algae in pools and other quiet waters (Smith, 1950). Some species occur in soft, acidic waters.

\section{ENVIRONMENTAL CONDITIONS}

\begin{tabular}{|c|c|c|c|}
\hline & Range & Mean & $\begin{array}{l}\text { Standard } \\
\text { deviation }\end{array}$ \\
\hline _____degrees Celsius___ & $0.0-$ & 19.1 & 7.7 \\
\hline 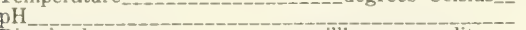 & $4.4-$ & 7.7 & .7 \\
\hline Dissolved oxygen & $.4-\quad 18.3$ & 8.5 & 2.4 \\
\hline Specific conductance & $25-24,800$ & 723 & 1,280 \\
\hline Total alkalinity____ milligrams per liter & -500 & 118 & 81 \\
\hline Total hardness & $-2,000$ & 203 & 206 \\
\hline Total nitrogen & $.00-\quad 17.0$ & 1.57 & 1.55 \\
\hline Total phosphorus & $.0-$ & .2 & .4 \\
\hline
\end{tabular}

\section{SPECIES INFORMATION}

Refer to Collins (1909), Smith (1920), and Prescott (1962). 


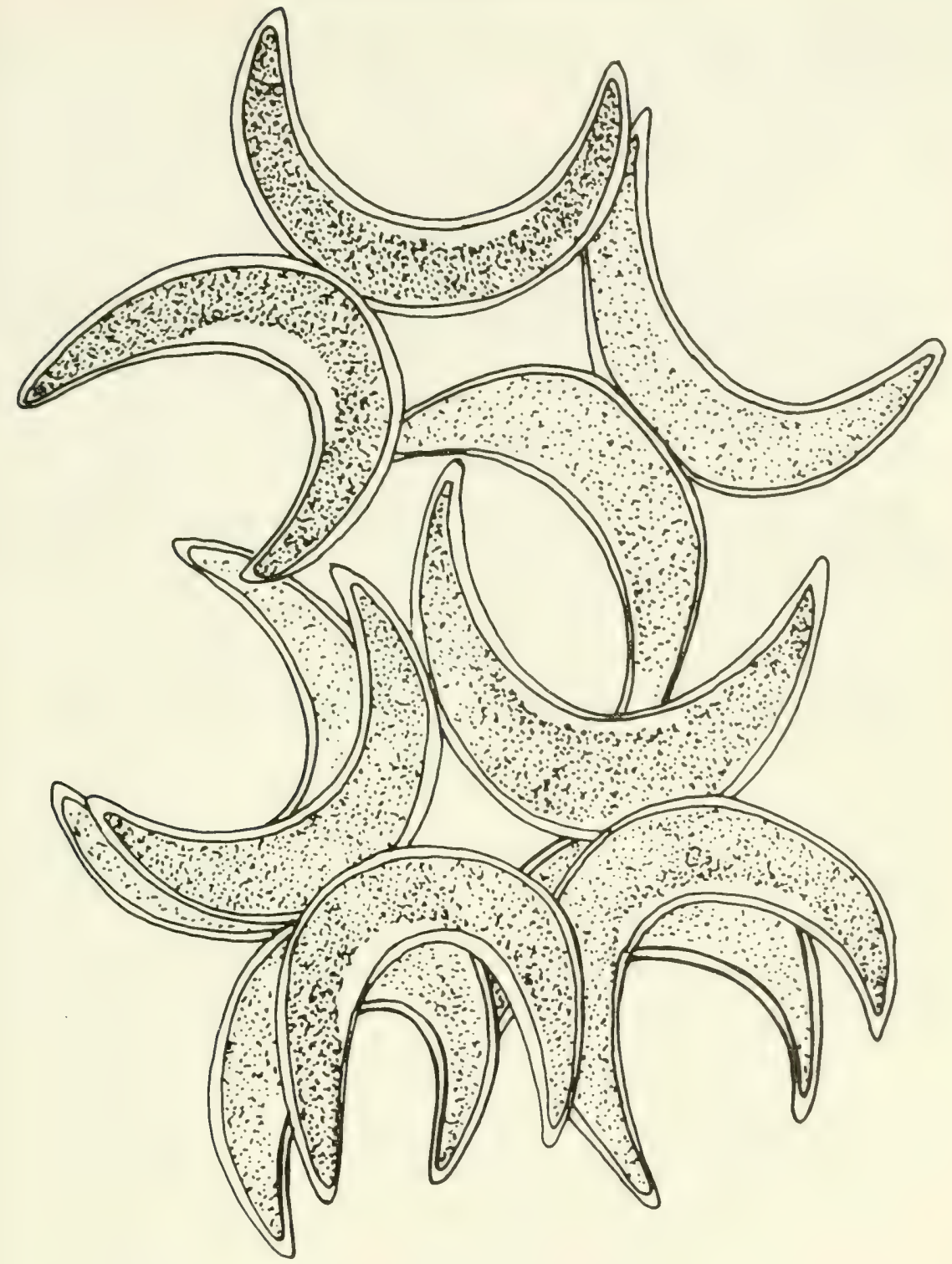

FIGURE 17. - Drawing of Selenastrum. 
Division Chlorophyta

Class Chlorophyceae

Order Tetrasporales

Family Palmellaceae

GENUS SPHAEROCYSTIS Chodat, 1897 (fig. 18)

\section{MORPHOLOGY}

Cells are spherical and are as much as $25 \mu \mathrm{m}$ in diameter. Cupshaped chromatophores may fill entire cell. The spherical colony consists of groups of $4,8,16$, or 32 cells arranged toward the periphery of a hyaline, homogeneous envelope.

\section{REPRODUCTION}

A colonial cell divides into 4 or 8 daughter cells, which are enveloped in a distinct gelatinous envelope. The daugher colony is released by a softening of the parent-colony matrix.

\section{OCCURRENCE}

The genus is widely distributed in the euplankton.

\section{ENVIRONMENTAL CONDITIONS}

\begin{tabular}{|c|c|c|c|}
\hline & Kange & Mean & $\begin{array}{l}\text { Standard } \\
\text { deviation }\end{array}$ \\
\hline _____degrees Celsius__ & $0.0-33.3$ & 20.9 & 6.7 \\
\hline 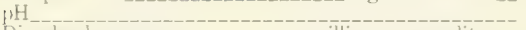 & $4.9-$ & 7.6 & .7 \\
\hline Dissolved oxygen____________milligrams per liter_- & $.4-15.9$ & 8.2 & 2.1 \\
\hline Specific conductance ___________ micromho _ & $10-9,800$ & 689 & 1,290 \\
\hline Total alkalinity_________ milligrams per liter__ & -400 & 107 & 80 \\
\hline Total hariness_______ & -1.800 & 189 & 237 \\
\hline Total nitrogen _._. & $.05-\quad 17.0$ & 1.49 & 1.93 \\
\hline Total phosphorus & $.0-$ & .2 & .2 \\
\hline
\end{tabular}

SPECIES INFORMATION

Refer to Smith (1920) and Prescott (1962). 


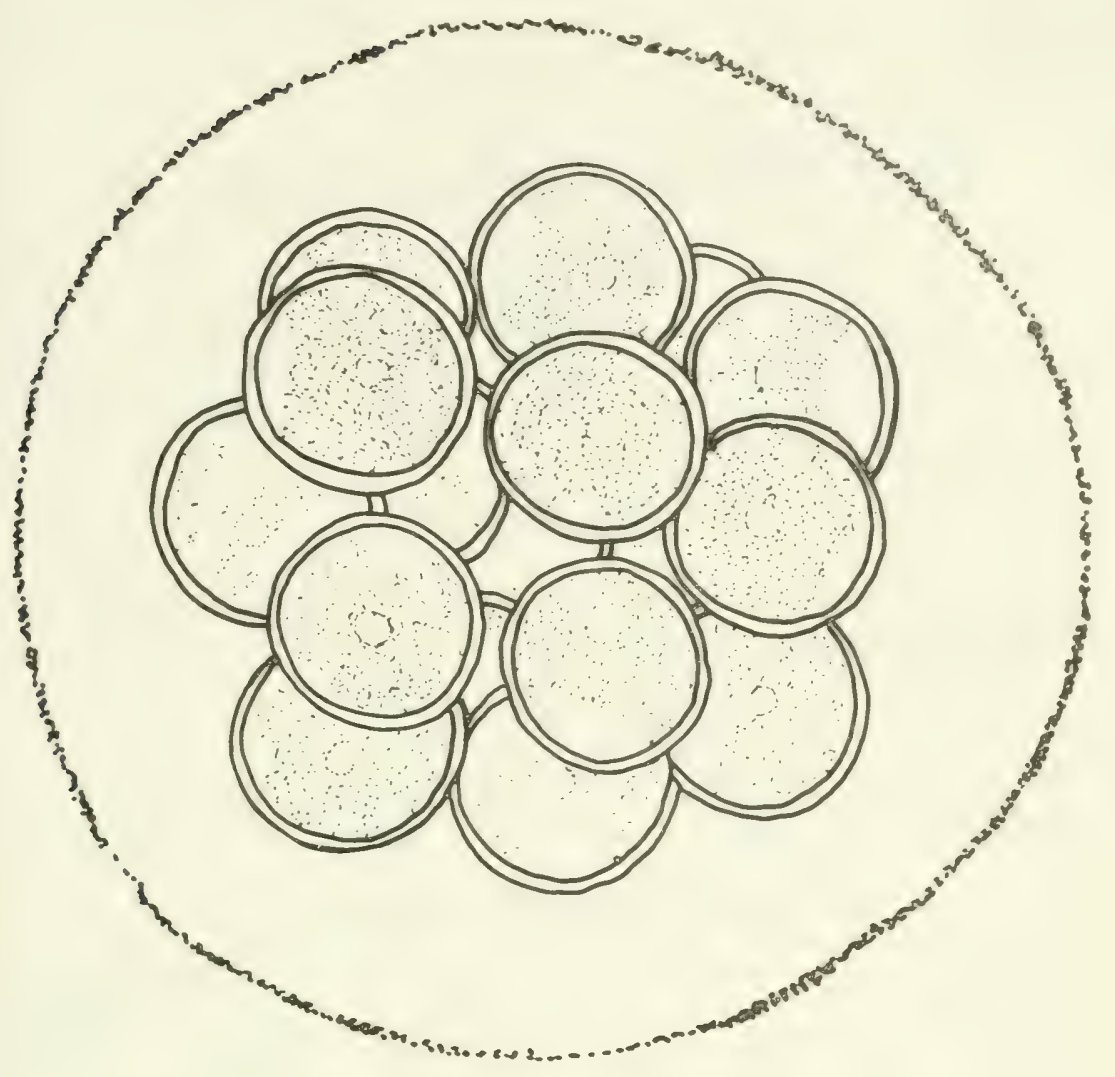

FiguRE 18.-Drawing of Sphaerocystis. 
Division Chlorophyta

Class Chlorophyceae

Order Chlorococcales

Family Oocystaceae

GENUS TETRAEDRON Kützing, 1845 (fig. 19)

\section{MORPHOLOGY}

Solitary cells are polyhedral. Angles of the cells may be simple or produced into simple or furcate processes. Cell wall may be smooth or verrucose. Cell may contain 1 to many parietal discoid to angular chromatophores.

\section{REPRODUCTION}

The cell divides into $2,4,8,16$, or 32 autospores, which are immediately released by rupture of the parent-cell wall.

\section{OCCURRENCE}

The genus is widely distributed, particularly in the euplankton and tychoplankton.

\section{ENVIRONMENTAL CONDITIONS}

\begin{tabular}{|c|c|c|c|}
\hline & Range & Mean & $\begin{array}{l}\text { Standard } \\
\text { deviation }\end{array}$ \\
\hline __degrees Cełsius__ & $0.0-$ & 20.8 & 6.8 \\
\hline $\mathrm{pH}$ & $4.7-$ & 7.7 & .6 \\
\hline milligrams per liter & $4-$ & 8.3 & 2.3 \\
\hline Specific conductance _._._._._._. micromho__ & $10^{-14,800}$ & 698 & 1,130 \\
\hline Total alkalinity. & $-\quad 440$ & 114 & 75 \\
\hline Total hardness & $6-1,800$ & 189 & 184 \\
\hline - & $.03-\quad 21.0$ & 1.37 & 1.50 \\
\hline Total phosphorus & $.0-$ & .2 & .3 \\
\hline
\end{tabular}

\section{SPECIES INFORMATION}

Refer to Brunnthaler (1915), Reinsch (1888), Smith (1920, 1926), and Prescott (1962). 
DESCRIPTION OF THE GENERA

51

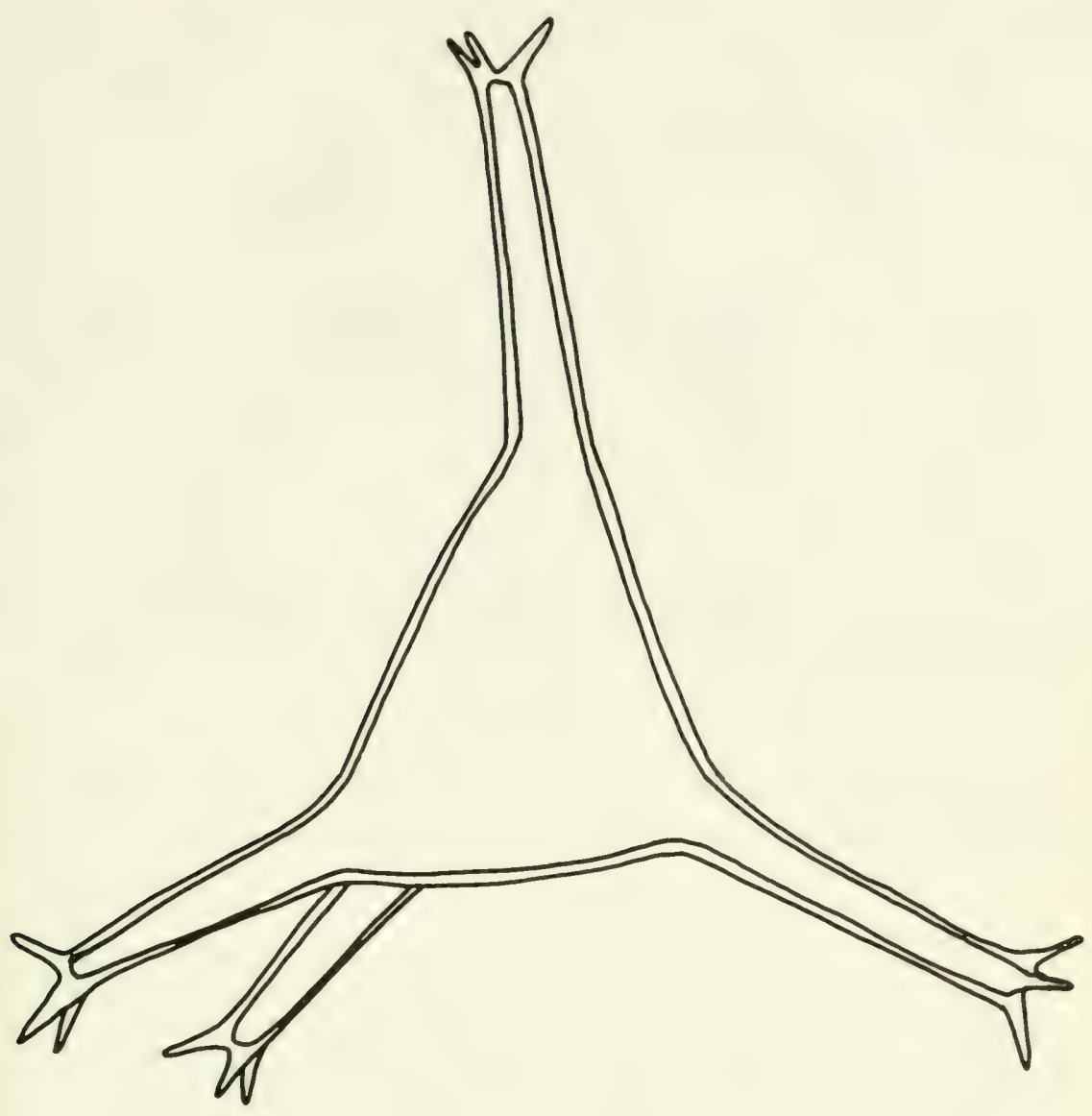

Figure 19. -Drawing of Tetraedron. 
Division Chlorophyta

Class Chlorophyceae

Order Chlorococcales

Family Scenedesmaceae

GENUS TETRASTRUM Chodat, 1895 (fig. 20)

\section{MORPHOLOGY}

Cells, 4-10 $\mu \mathrm{m}$ in diameter, are elliptical, triangular, trapezoidal, or semicircular. Each cell has one or more spines on the free face. One to 4 cup-shaped chromatophores are parietal. Cells are joined quadrately to form a 4-celled coenobia.

\section{REPRODUCTION}

A cell divides into 4 autospores that remain quadrately attached. Cellular spines develop following release by rupture of the parent-cell wall.

\section{OCCURRENCE}

Tetrastrum has a widespread distribution, but it is found generally only in very few numbers. It is common in the euplankton.

ENVIRONMENTAL CONDITIONS

\begin{tabular}{|c|c|c|c|}
\hline & Range & Mean & $\begin{array}{l}\text { Standard } \\
\text { deviation }\end{array}$ \\
\hline 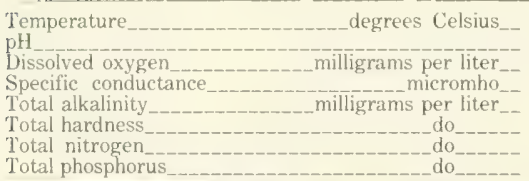 & $\begin{array}{r}0.0-34.0 \\
4.9-9.4 \\
1.7-19.7 \\
10-9,800 \\
2-477 \\
5-2.000 \\
.01-19.0 \\
.0-3.7\end{array}$ & $\begin{array}{c}19.1 \\
7.8 \\
8.8 \\
741 \\
129 \\
215 \\
1.72 \\
.2\end{array}$ & $\begin{array}{c}7.8 \\
.6 \\
2.3 \\
998 \\
76 \\
184 \\
1.71 \\
.3\end{array}$ \\
\hline
\end{tabular}

\section{SPECIES INFORMATION}

Refer to Ahlstrom and Tiffany (1934) and Prescott (1962). 


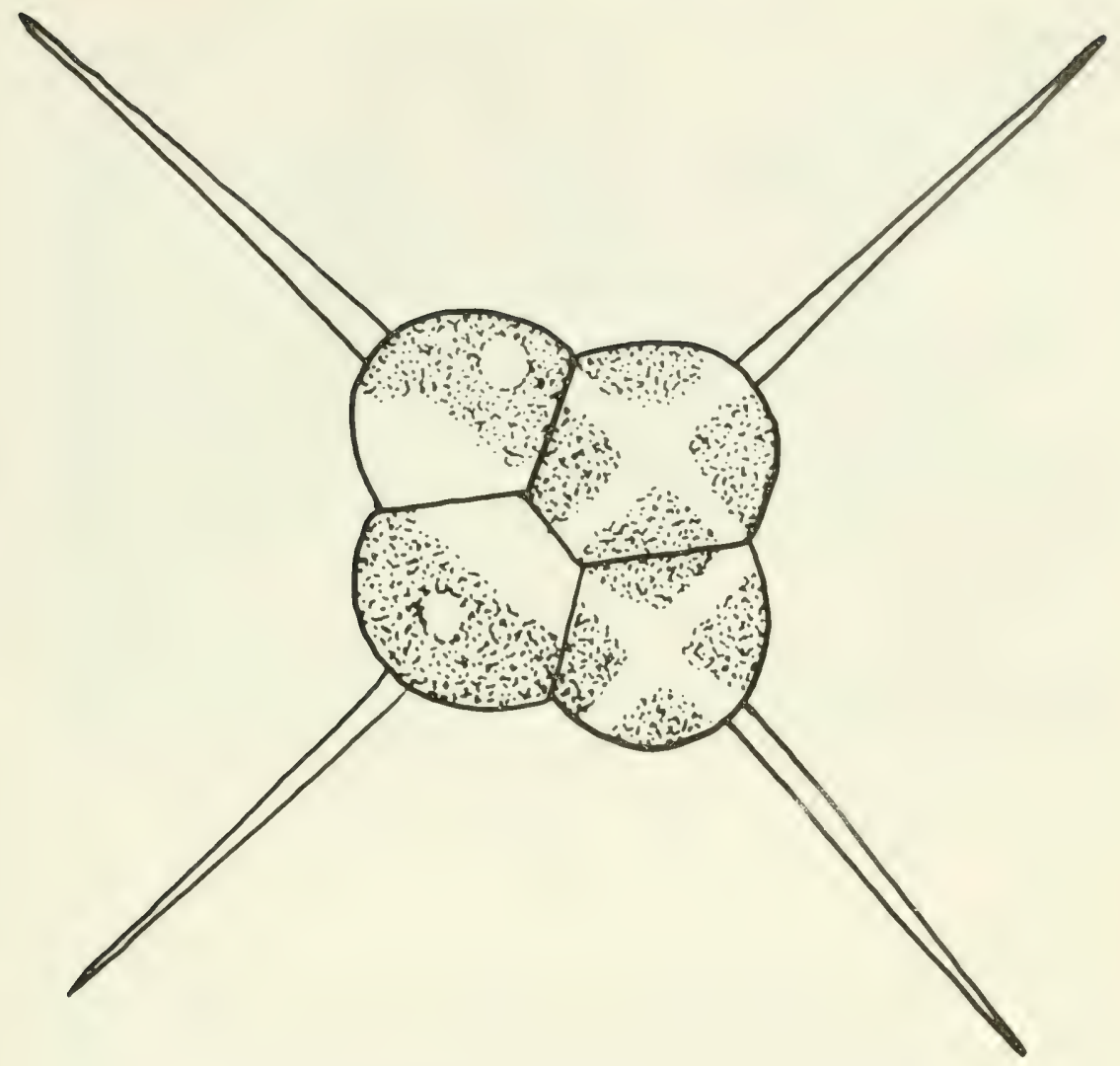

FIGURE 20.-Drawing of Tetrastrum. 


\section{Division Euglenophyta}

Class Euglenophyceae

Order Euglenales

Family Euglenaceae

GENUS EUGLENA Ehrenberg, 1838 (fig. 21)

\section{MORPHOLOGY}

Cell is elongate, oblong, lanceolate, or spindle shaped; rigidly or spirally twisted; solitary; sometimes attenuate at posterior end; and as much as $450 \mu \mathrm{m}$ in length. Each cell contains a single flagellum. A cell has a gullet at the anterior end and one or more contractile vacuoles adjoining a flask-shaped reservoir. Eyespot is generally present. Chromatophores are numerous and discoid to band shaped.

\section{REPRODUCTION}

Reproduction is by longitudinal division of the cell beginning at the anterior end. Occasionally, a cell becomes immobile and surrounded by a gelatinous sheath, following which cell division occurs. This is called a palmelloid colony.

\section{OCCURRENCE}

Euglena is of widespread distribution mostly in the tychoplankton. It is very indicative of waters rich in organic matter, for example, those below domestic sewage outfalls. It can occur in such abundance as to color the water a deep green (Smith, 1950). Occasionally, the lightinduced production of haematochrome in abundant cells will color a body of water brick red (Prescott, 1962).

\section{ENVIRONMENTAL CONDITIONS}

\begin{tabular}{|c|c|c|c|}
\hline & Range & Mean & $\begin{array}{l}\text { Standard } \\
\text { deviation }\end{array}$ \\
\hline ______degrees Celsius___ & $0.0-$ & 18.3 & 8.4 \\
\hline $\mathrm{pH}_{-}$ & $4.1-$ & 7.7 & .6 \\
\hline Dissolved oxygen___________milligrams per liter & $.1-$ & 8.6 & 2.8 \\
\hline Specific conductance __________ micromho _-_ & $10-48,000$ & 1,240 & 2,680 \\
\hline Total alkalinity_________milligrams per liter__ & -500 & 146 & 88 \\
\hline Total hardness____________ & $-2,000$ & 284 & 299 \\
\hline Total nitrogen_____ & 28.0 & 2.11 & 2.59 \\
\hline Total phosphorus__________ & $.0-$ & .3 & .5 \\
\hline
\end{tabular}

\section{SPECIES INFORMATION}

Refer to Johnson (1944) and Prescott (1962). 


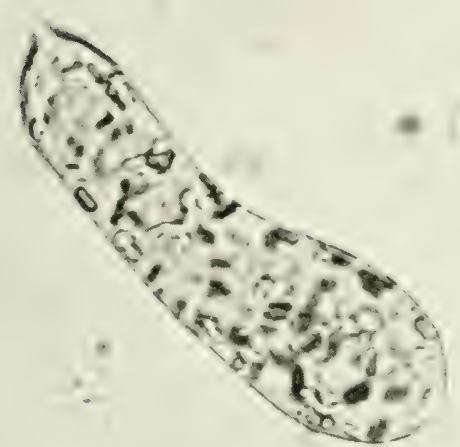

FIGURE 21. - Photomicrograph of Euglena. 
Division Euglenophyta

Class Euglenophyceae

Order Euglenales

Family Euglenaceae

GENUS TRACHELOMONAS Ehrenberg, 1833 (fig. 22)

MORPHOLOGY

Cell is solitary and uniflagellate and loosely encased in a globose or ellipsoidal lorica. The surface of the lorica may be smooth, punctate, spiny, reticulate, or striate. There are 2 to 15 parietal, discoid chromatophores.

\section{REPRODUCTION}

Prior to division into 2 daughter cells, the parent cell becomes immobile. One daughter cell is released to form a new lorica. The remaining daughter cell retains the parent-cell lorica.

\section{OCCURRENCE}

The genus is very indicative of warm waters having a high content of organic matter. It can occur in such abundance as to color the water brown. It is found primarily in the tychoplankton.

ENVIRONMENTAL CONDITIONS

\begin{tabular}{|c|c|c|c|}
\hline & Range & Mean & $\begin{array}{l}\text { Standard } \\
\text { deviation }\end{array}$ \\
\hline $\begin{array}{l}\text { Temperature__________degrees Celsius } \\
\mathrm{pH}\end{array}$ & $0.0-\quad 34.0$ & 18.3 & 8.5 \\
\hline Dissolved oxygen & $\begin{array}{r}4.0- \\
.2-\end{array}$ & 8.6 & .7 .6 \\
\hline Specific conductance & $10^{-4}-48,000$ & 753 & $1,970^{\circ}$ \\
\hline Total alkalinity & $0-500$ & 113 & 83 \\
\hline Total hardness & $3-1,800$ & 197 & 222 \\
\hline Total nitrogen & $.02-\quad 38.0$ & 1.60 & 1.87 \\
\hline Total phosphorus & $.0-$ & .2 & .3 \\
\hline
\end{tabular}

\section{SPECIES INFORMATION}

Refer to Deflandre (1926), Skvortzow (1925), and Prescott (1962). 


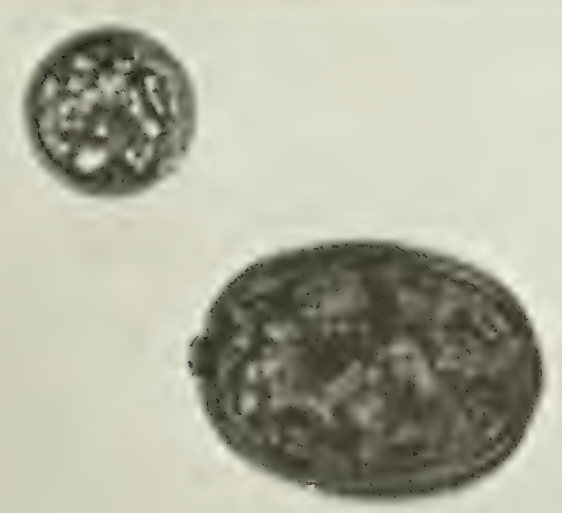

FIgURE 22.-Photomicrograph of Trachelomonas. 
Division Chrysophyta

Class Bacillariophyceae

Order Pennales

Family Achnanthaceae

GENUS ACHNANTHES Bory, 1822 (fig. 23)

\section{MORPHOLOGY}

Cells are rectangular and longitudinally bent or curved in girdle view. They generally are attached by gelatinous stalks or are sessile and united into bundles at the valves, rarely into filaments. Values are generally linear-lanceolate to elliptical. The epitheca is convex and has a pseudoraphe; the hypotheca is commonly concave and has a raphe, inconspicuous polar nodules, a distinct center nodule, and sometimes a stauros. Striae are transverse or radiate. Costae are prominant in some species. There are 1, 2, or numerous discoid chromatophores.

\section{REPRODUCTION}

Auxospore formation is by conjugation of paired gametes, 2 of which are formed from each of 2 protoplasts.

\section{OCCURRENCE}

The genus is widely distributed. Freshwater species are generally epiphytic upon filamentous chlorophytes and submerged phanerogams. They are found frequently in the tychoplankton.

\section{ENVIRONMENTAL CONDITIONS}

\begin{tabular}{|c|c|c|c|}
\hline & Range & Mean & $\begin{array}{l}\text { Standard } \\
\text { deviation }\end{array}$ \\
\hline 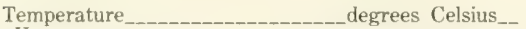 & $0.0-$ & 13.4 & 8.3 \\
\hline - & $3.4-$ & 7.5 & .7 \\
\hline Dissolved oxygen & $.8-$ & 9.7 & 2.4 \\
\hline Specific conductance & $10-37,400$ & 539 & 1,290 \\
\hline Total alkalinity__.__ milligrams per liter & $-\quad 480$ & 95 & 76 \\
\hline Total hardness__. $\mathrm{do}$ & $-2,000$ & 164 & 226 \\
\hline Total nitrogen & $.00-\quad 32.0$ & 1.12 & 1.42 \\
\hline Total phosphorus & $.0-$ & .1 & .3 \\
\hline
\end{tabular}

SPECIES INFORMATION

Refer to Boyer (1927a) and Patrick and Reimer (1966). 


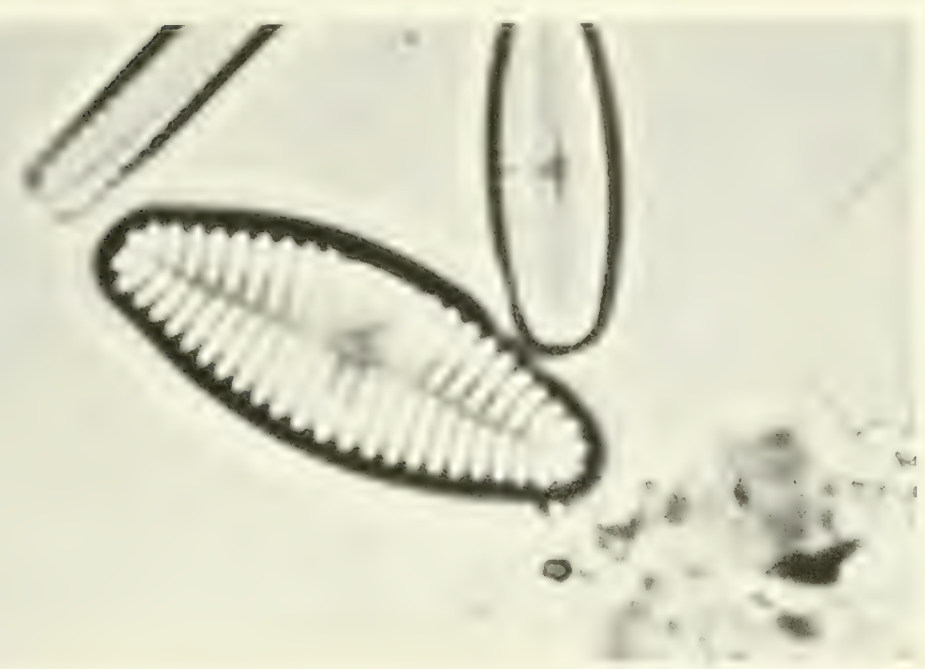

FigURE 23. - Photomicrograph of Achnanthes. 
Division Chrysophyta

Class Bacillariophyceae

Order Pennales

Family Cymbellaceae

GENUS AMPHORA Ehrenberg, 1840 (fig. 24)

\section{MORPHOLOGY}

Cells are commonly sessile, with concave faces attached in girdle view. They are broadly elliptical in outline and have truncated ends. Girdles generally are separated by several punctate or striate intercalary bands. Values are lunate, longitudinally asymmetrical, and transversely striate. Raphe is gibbous, with a central nodule close to the concave margin. Some species have a single chromatophore which lies next to the concave girdle face; other species have 2 or 4 chromatophores.

\section{REPRODUCTION}

Two gametes are formed from the protoplast of 2 approximate cells and unite to form 2 auxospores. Geitler (1929) observed the production of a single auxospore from a single cell.

\section{OCCURRENCE}

Amphora is widely distributed. Freshwater species commonly are found in circumneutral waters having a fairly high nutrient content.

ENVIRONMENTAL CONDITIONS

\begin{tabular}{|c|c|c|c|}
\hline & Range & Mean & $\begin{array}{l}\text { Standard } \\
\text { deviation }\end{array}$ \\
\hline 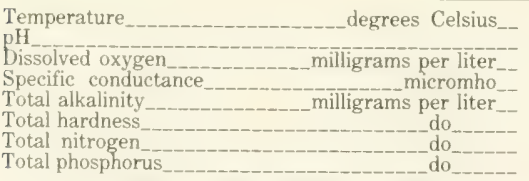 & $\begin{array}{rr}0.0- & 34.0 \\
4.9- & 9.6 \\
2.7 & 20.0 \\
22 & -48,600 \\
0 & -480 \\
4 & -2,000 \\
.00- & 38.0 \\
.0-\quad 3.6\end{array}$ & $\begin{array}{c}14.3 \\
7.8 \\
9.6 \\
1,860 \\
137 \\
269 \\
1.64 \\
.2\end{array}$ & $\begin{array}{r}8.4 \\
.6 \\
2.3 \\
5,500 \\
81 \\
281 \\
2.50 \\
.4\end{array}$ \\
\hline
\end{tabular}

\section{SPECIES INFORMATION}

Refer to Cleve (1895) and Boyer (1927a). 


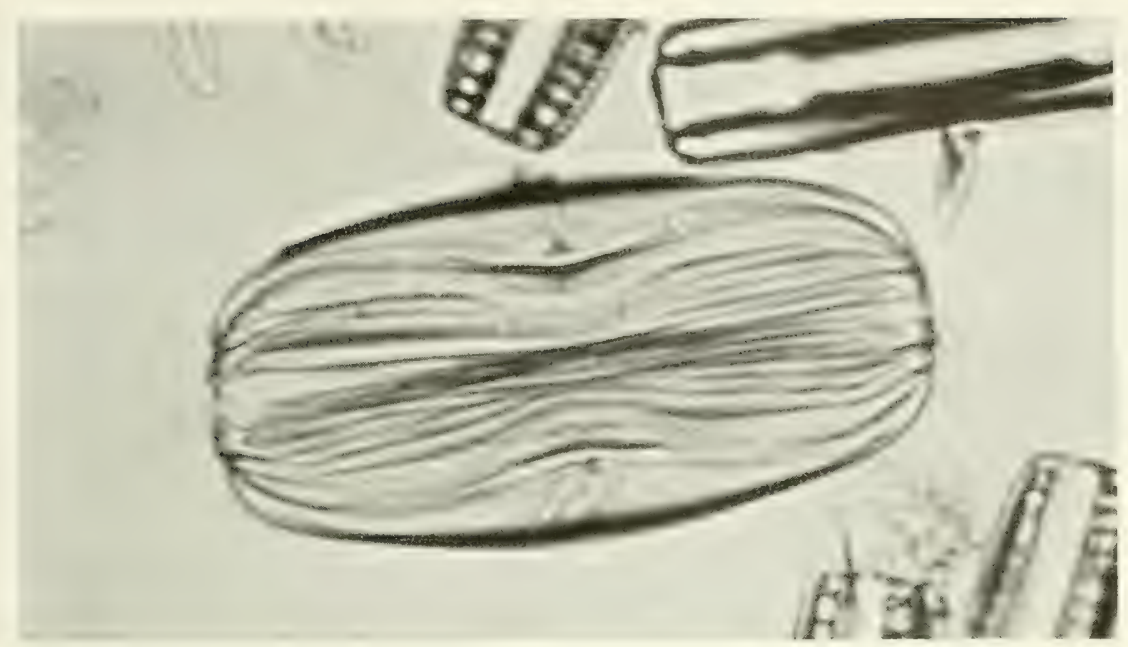

Figure 24.-Photomicrograph of Amphora. 
Division Chrysophyta

Class Bacillariophyceae

Order Pennales

Family Fragilariaceae

GENUS ASTERIONELLA Hassall, 1850 (fig. 25)

\section{MORPHOLOGY}

Cells are joined to one another at their ends to form flat stellate colonies. Cell length may reach $130 \mu \mathrm{m}$; cell diameter is about $1-2 \mu \mathrm{m}$. Valves are linear with inflated ends and are symmetrical in valve and girdle views. They are finely transversely striated. Intercalary bands, septa, and costae are lacking. The pseudoraphe is indistinct. There are 2 (generally) to several lobed chromatophores.

\section{REPRODUCTION}

Reproduction is probably by the formation of an auxospore within a single cell.

\section{OCCURRENCE}

Asterionella is a commonly occurring alga in the euplankton. It is indicative of mesotrophic to eutrophic conditions. They may occur in such abundance as to impart a fishy taste to the water (Whipple and others, 1948).

\section{ENVIRONMENTAL CONDITIONS}

\begin{tabular}{|c|c|c|c|}
\hline & Range & Mean & $\begin{array}{l}\text { Standard } \\
\text { deviation }\end{array}$ \\
\hline 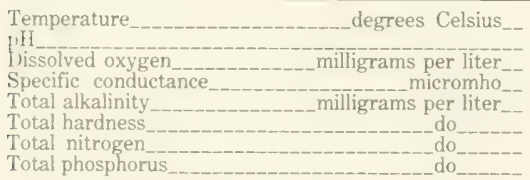 & $\begin{array}{r}0.0-31.0 \\
4.7-9.4 \\
2.0-16.6 \\
19-8.000 \\
0-371 \\
2-1,400 \\
.01-14.0 \\
.0-\quad 2.3\end{array}$ & $\begin{array}{c}10.6 \\
7.6 \\
10.3 \\
342 \\
92 \\
127 \\
1.13 \\
.1\end{array}$ & $\begin{array}{c}7.5 \\
.6 \\
2.2 \\
389 \\
63 \\
104 \\
1.14 \\
.1\end{array}$ \\
\hline
\end{tabular}

\section{SPECIES INFORMATION}

Refer to Meister (1912), Boyer (1927a), and Patrick and Reimer (1966). 


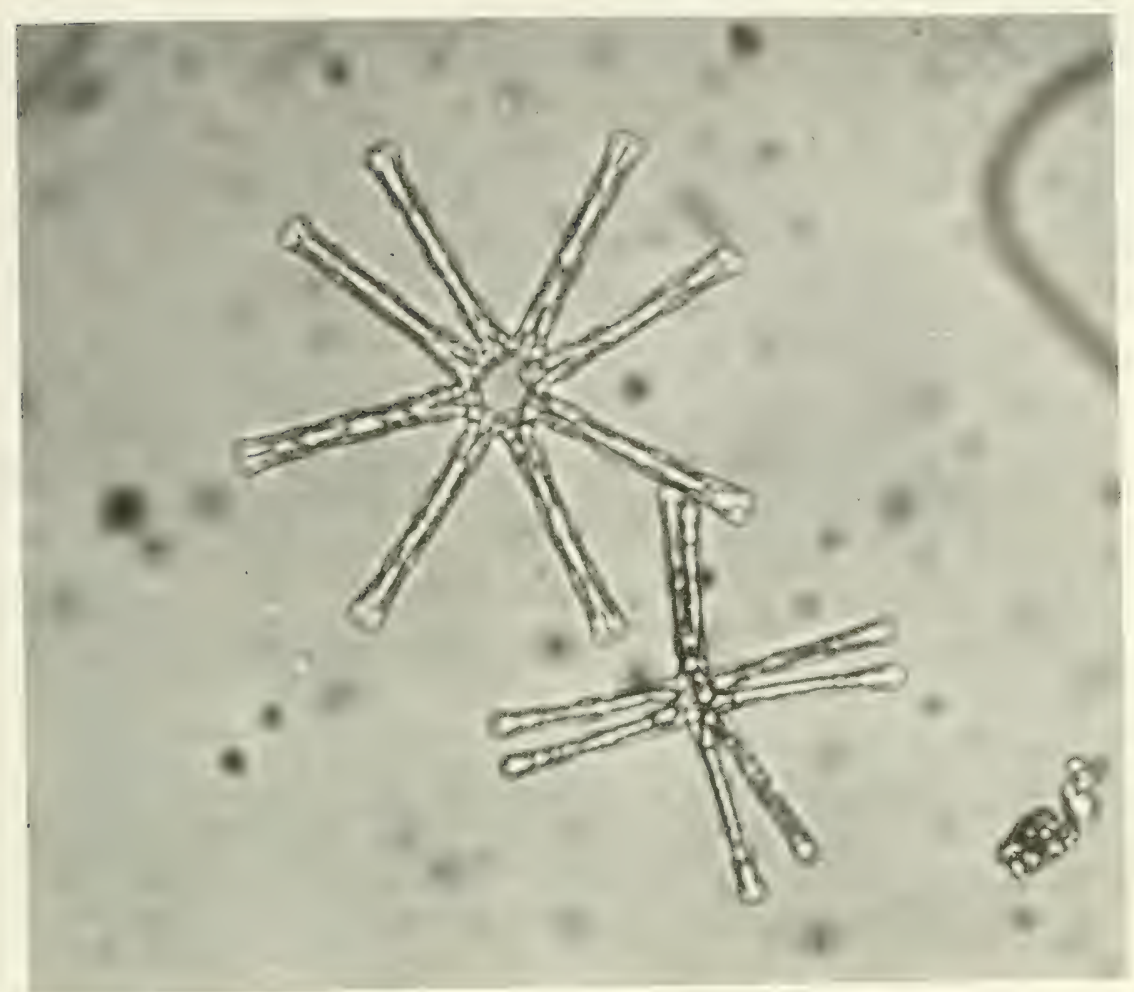

Figure 25.-Photomicrograph of Asterionella. 


\section{Division Chrysophyta}

Class Bacillariophyceae

Order Pennales

Family Achnanthacea

GENUS COCCONEIS Ehrenberg, 1838 (fig. 26)

\section{MORPHOLOGY}

Solitary cells are transversely curved in girdle view and broadly olliptical in valve view. Epitheca has an axial pseudoraphe and transverse striae or punctae. Hypotheca has a median raphe that is straight or sigmoid and has a central or polar nodule. Striae and punctae generally are transverse. A single, laminate chromatophore adjoins the epitheca.

\section{REPRODUCTION}

A single auxospore is formed by the conjugation of 2 approximate cells.

\section{OCCURRENCE}

Species of the genus are almost exclusively epiphytic upon filamentous chlorophytes. It is widely distributed. Occurrence of the genus in the plankton generally results from sloughing of the periphyton.

\section{ENVIRONMENTAL CONDITIONS}

\begin{tabular}{|c|c|c|c|}
\hline & Range & Mean & $\begin{array}{l}\text { Standard } \\
\text { deviation }\end{array}$ \\
\hline _.__________egrees Celsius__ & $0.0-$ & 14.4 & 8.5 \\
\hline $\mathrm{pH}$ & $4.1-$ & 7.7 & .6 \\
\hline Dissolved oxygen & $.8-$ & 9.4 & 2.3 \\
\hline Specific conductance & $10^{-48,000}$ & 578 & 1,450 \\
\hline Total alkalinity & $-\quad 480$ & 114 & 75 \\
\hline Total hardness & $4-2,000$ & 169 & 165 \\
\hline - & $.00-\quad 38.0$ & 1.19 & 1.63 \\
\hline Total phosphorus & $.0-$ & .2 & .3 \\
\hline
\end{tabular}

\section{SPECIES INFORMATION}

Refer to Boyer (1927a) and Patrick and Reimer (1966). 


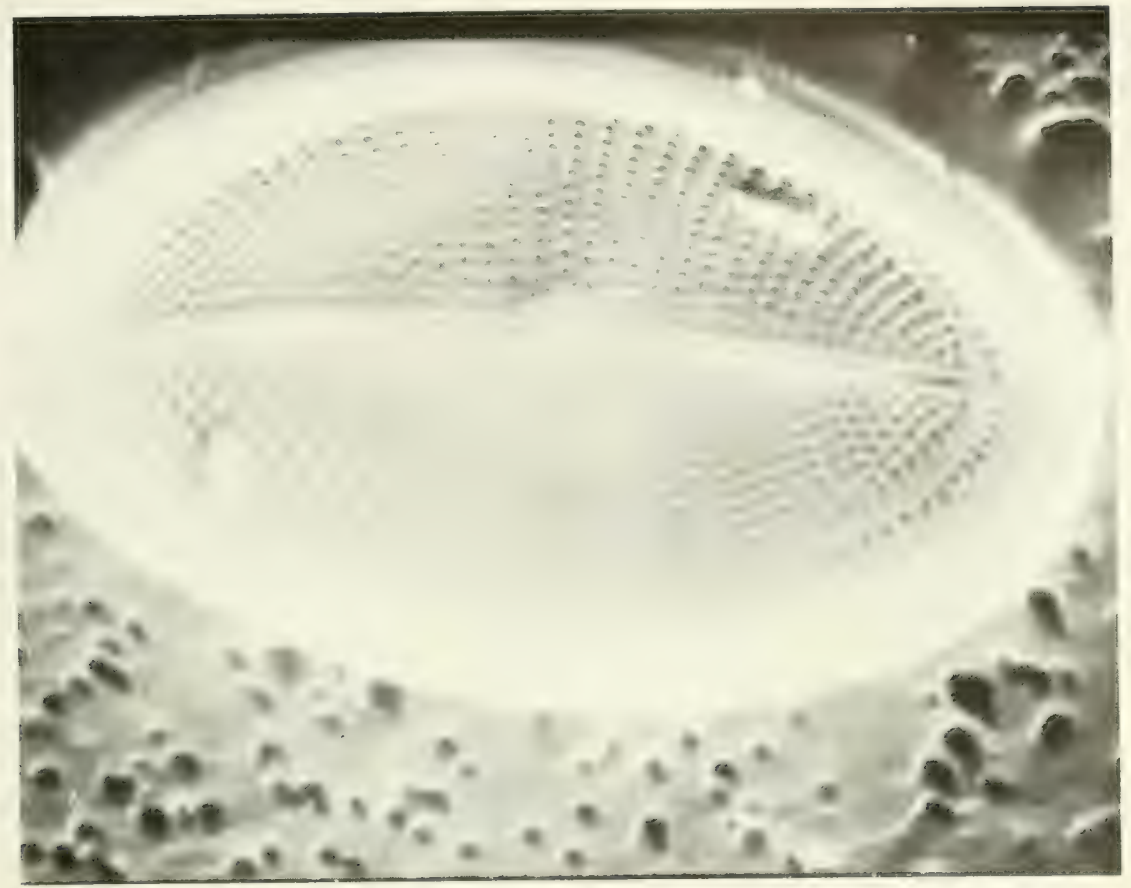

Figure 26. -Scanning electronmicrograph of Cocconeis. 
Division Chrysophyta

Class Bacillariophyceae

Order Centrales

Family Coscinodiscaceae

GENUS CYCLOTELLA Kützing, 1834 (fig. 27)

\section{MORPHOLOGY}

Discoid, drum-shaped cells are solitary (generally), filamentous, or in a colonial gelatinous envelope. The valve view is circular or rarely elliptical. Ornamentation is in 2 concentric regions: the outer region is radially striate or punctate, and the inner region is smooth or very finely punctate. Intercalary bands are lacking. There are numerous small, discoid chromatophores.

\section{REPRODUCTION}

A single auxospore is formed within a cell.

\section{OCCURRENCE}

The genus is widely distributed in all types of surface waters.

ENVIRONMENTAL CONDITIONS

\begin{tabular}{|c|c|c|c|}
\hline & Range & Mean & $\begin{array}{l}\text { Standard } \\
\text { deviation }\end{array}$ \\
\hline 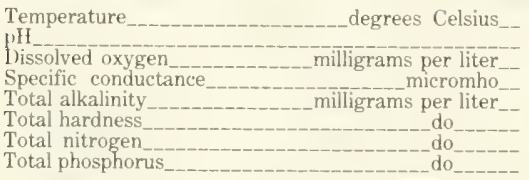 & $\begin{array}{rr}0.0- & 37.0 \\
3.4- & 10.0 \\
1-1 & 22.0 \\
10 & -49,800 \\
0 & -500 \\
3-2,000 \\
.00- & 41.0 \\
.0- & 4.0\end{array}$ & $\begin{array}{c}16.1 \\
7.7 \\
9.1 \\
918 \\
119 \\
217 \\
1.58 \\
.2\end{array}$ & $\begin{array}{c}8.7 \\
.6 \\
2.5 \\
2,570 \\
78 \\
250 \\
1.96 \\
.4\end{array}$ \\
\hline
\end{tabular}

\section{SPECIES INFORMATION}

Refer to Boyer (1927a). 


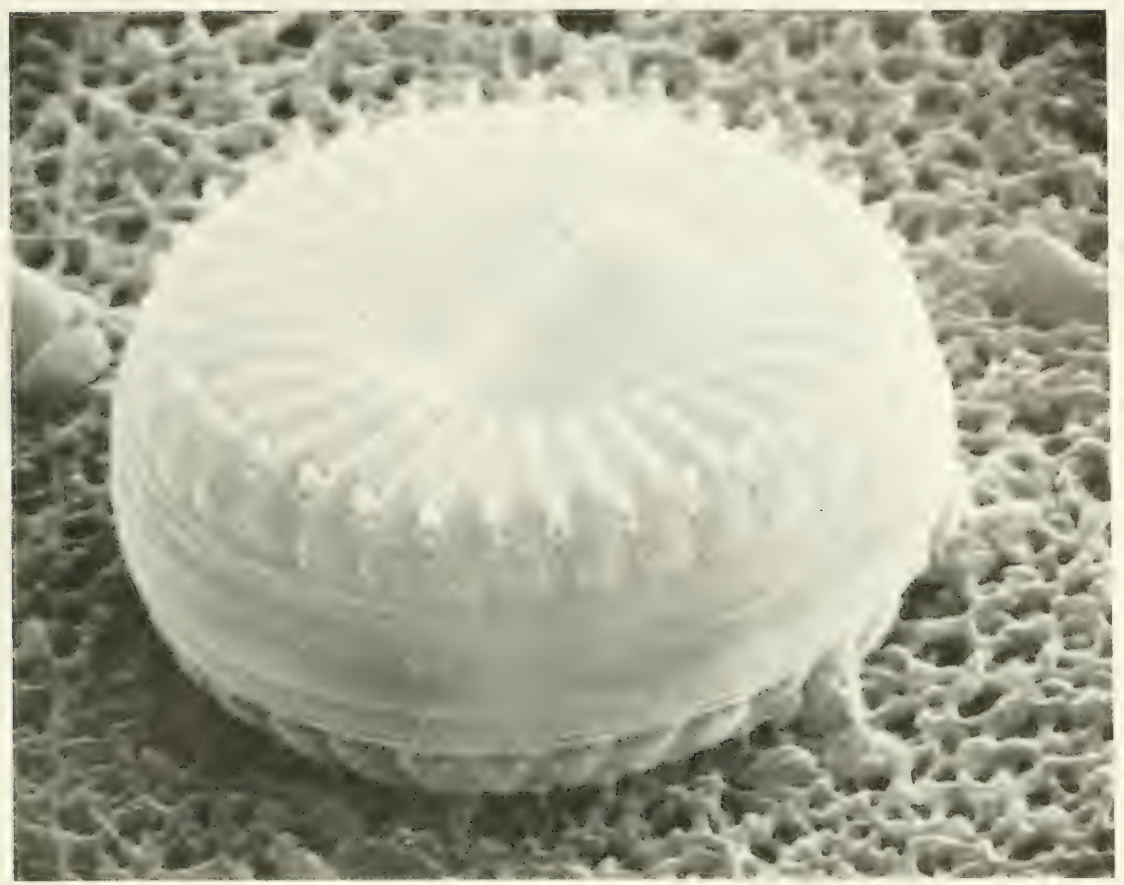

FIGURE 27.-Scanning electronmicrograph of Cyclotella. 
Division Chrysophyta

Class Bacillariophyceae

Order Pennales

Family Cymbellaceae

GENUS CYMBELLA Agardh, 1830 (fig. 28)

\section{MORPHOLOGY}

Solitary cells are free floating, attached at the ends of gelatinous stalks, or contained within branched gelatinous tubes. Cell is longitudinally asymmetrical in valve view and is lunate, subellipitical, rhombic, or naviculoid. It is ventrally concave and dorsally convex. The raphe is curved and contains well-defined nodules. Ornamentations consist of radiating transverse striae or punctae. Intercalary bands are lacking. A single chromatophore is plate shaped.

\section{REPRODUCTION}

Two gamates are formed from the protoplast of 2 approximate cells and unite to form 2 auxospores.

\section{OCCURRENCE}

A distinctly freshwater genus, Cymbella is widely distributed in the euplankton.

\section{ENVIRONMENTAL CONDITIONS}

\begin{tabular}{|c|c|c|c|}
\hline & Range & Mean & $\begin{array}{l}\text { Standard } \\
\text { deviation }\end{array}$ \\
\hline $\begin{array}{l}\text { Temperature__________egrees Celsius__ } \\
\mathrm{nH}\end{array}$ & $0.0-\quad 34.0$ & 13.5 & 8.2 \\
\hline Dissolved oxygen & $1.1-$ & 9.7 & 2.2 \\
\hline _-___ micromho_- & $10-49,800$ & 647 & $2,250^{\circ}$ \\
\hline Total alkalinity & $\begin{array}{l}-430 \\
-\quad 430\end{array}$ & 100 & 74 \\
\hline Total hardness & $-2,000$ & 164 & 194 \\
\hline Total nitrogen & $.00-$ & 1.17 & 1.53 \\
\hline Total phosphorus & $.0-$ & .1 & .3 \\
\hline
\end{tabular}

\section{SPECIES INFORMATION}

Refer to Boyer (1927a). 
. 
Division Chrysophyta

Class Bacillariophyceae

Order Pennales

Family Diatomaceae

GENUS DIATOMA DeCandolle, 1805 (fig. 29)

\section{MORPHOLOGY}

Cells are rectangularly tabular in girdle view and united at the corner into free-floating or sessile zigzag to linear chains. There are 1 to 2 intercalary bands. Several transverse septa appear as transverse costae. Cells are lanceolate to linear and bilaterally symmetrical. Valves contain transverse, finely punctate striations between the costae. The narrow pseudoraphe does not have a median expansion. Numerous chromatophores are elliptical.

\section{REPRODUCTION}

A single auxospore is formed within a cell.

\section{OCCURRENCE}

The genus is widely distributed in cool water. Some species are indicative of particular environmental conditions.

\section{ENVIRONMENTAL CONDITIONS}

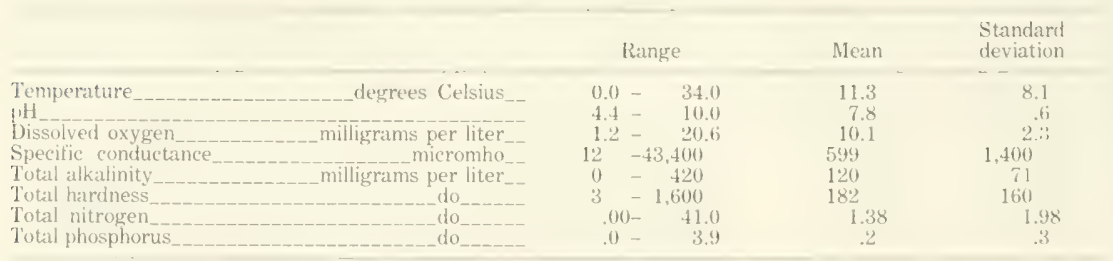

SPECIES INFORMATION

Refer to Boyer (1927a) and Patrick and Reimer (1966). 


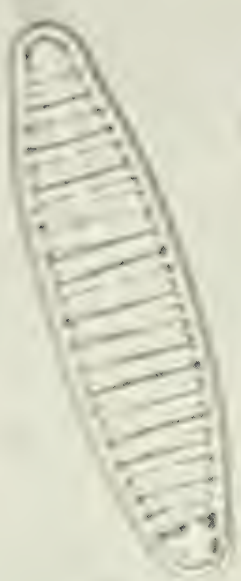

Figure 29.-Photomicrograph of Diatoma. 
Division Chrysophyta

Class Chrysophyceae

Order Chrysomonadales

Family Ochromonadaceae

GENUS DINOBRYON Ehrenberg, 1835 (fig. 30)

\section{MORPHOLOGY}

Cells are free floating, sessile, or ephiphytic and may be solitary or in colonies. They are enclosed in conical, campanulate, or cylindrical cellulose lorica, which have smooth or undulate walls, pointed bases, and open tops. Colonies may be arbuscular, divergent, or compact. The conical or ovoid protoplast is attached to the base or side of the lorica and contains 2 flagella of unequal length. Each cell has 1 to 2 elongate, parietal, golden-brown chromatophores, several contractile vacuoles, and 1 apical eyespot.

\section{REPRODUCTION}

Longitudinal division of a cell results in 2 daughter cells, which become attached to the mouth of the parent-cell lorica. New lorica are formed. Pascher (1943) observed both palmelloid stages and statospores.

\section{OCCURRENCE}

Dinobryon is widely distributed and generally is indicative of hard waters. It commonly is intermingled with other algae in pools and ditches (Smith, 1950).

\section{ENVIRONMENTAL CONDITIONS}

\begin{tabular}{|c|c|c|c|}
\hline & Range & Mean & $\begin{array}{l}\text { Standard } \\
\text { deviation }\end{array}$ \\
\hline ___-_degrees Celsius___ & $0.0-33.5$ & 13.6 & 8.3 \\
\hline $\mathrm{pH}$ & $4.1-$ & 7.4 & .7 \\
\hline Dissolved oxygen & $.7-14.7$ & 9.7 & 2.4 \\
\hline Specific conductance & $11-7,700$ & 313 & 447 \\
\hline Total alkalinity & -477 & 83 & 72 \\
\hline Total hardness & $5-1,700$ & 122 & 134 \\
\hline Total nitrogen & $.00-\quad 12.0$ & .91 & .99 \\
\hline Total phosphorus & $.0-$ & .1 & .1 \\
\hline
\end{tabular}

\section{SPECIES INFORMATION}

Refer to Ahlstrom (1937). 


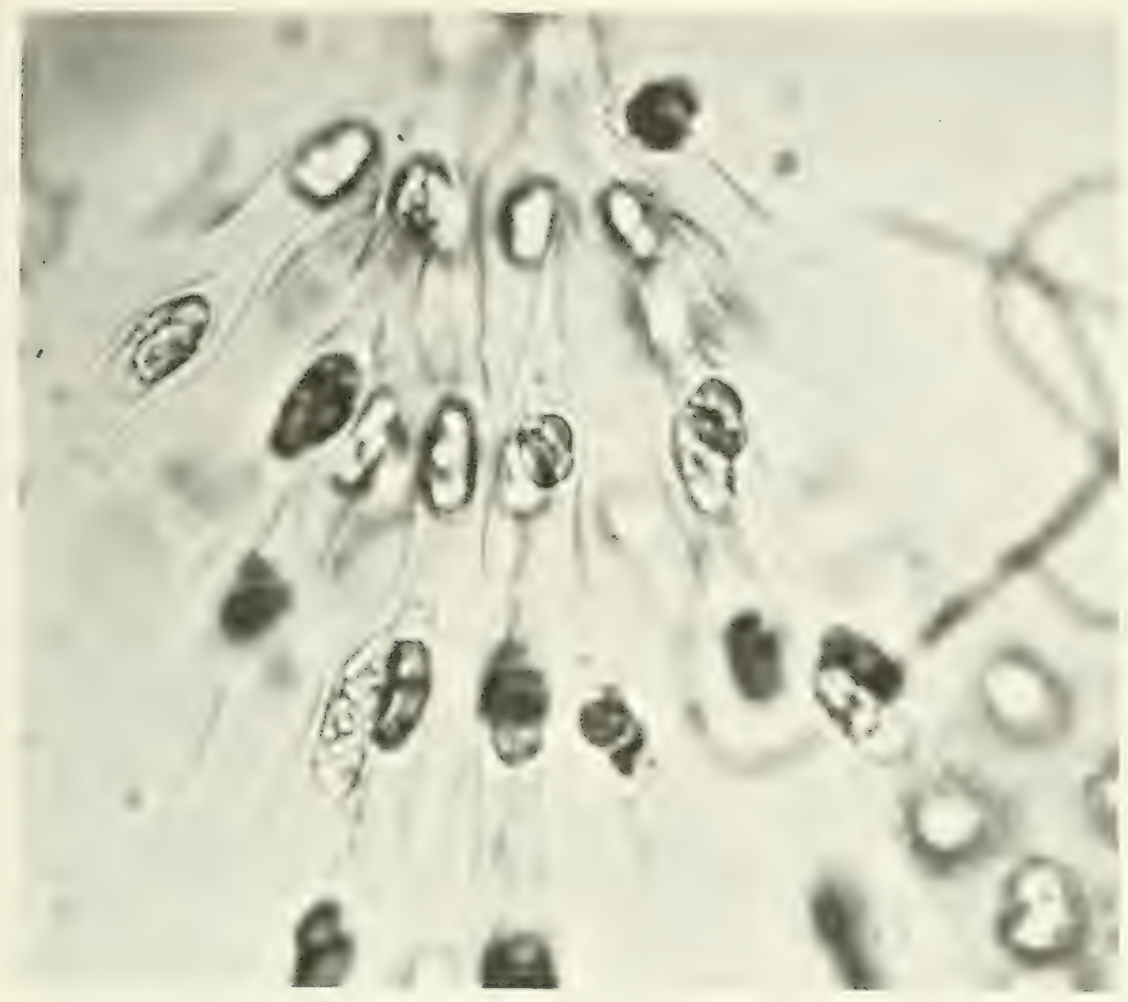

FIGURE 30.-Photomicrograph of Dinobryon. 
Division Chrysophyta

Class Bacillariophyceae

Order Pennales

Family Cymbellaceae

GENUS EPITHEMIA de Brébisson, 1838 (fig. 31)

\section{MORPHOLOGY}

The solitary cells are commonly epiphytic upon submerged macrophytes. They are attached at the girdle, are rectangular in girdle view, and have smooth girdles and intercalary bands. Valves are slightly to strongly curved dorsally convex, and ventrally straight to concave. Poles are broadly rounded to capitate and sometimes recurved. The axial field is next to the concave side, but its central portion bends sharply inward to form a V-shaped structure midway between the poles. A raphe contains polar and central nodules. Transverse septa appear as costae and alternate with 2 or more rows of punctae. There is generally a single chromatophore next to the concave girdle side, which has irregular projections extending along both valve faces.

\section{REPRODUCTION}

Protoplasts of approximate frustules each form 2 gametes, which unite to form 2 auxospores.

\section{OCCURRENCE}

The genus is widely distributed, particularly in the tychoplankton.

ENVIRONMENTAL CONDITIONS

\begin{tabular}{|c|c|c|c|}
\hline & Range & Mean & $\begin{array}{l}\text { Standard } \\
\text { deviation }\end{array}$ \\
\hline 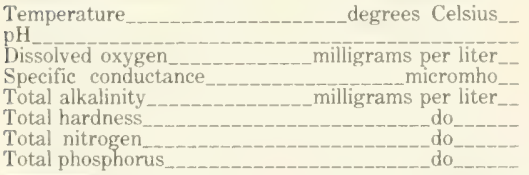 & $\begin{array}{rr}0.0 & -32.0 \\
3.7 & -9.2 \\
3.9 & 15.1 \\
30 & -40,100 \\
0 & =350 \\
5 & =1,700 \\
.00- & 36.0 \\
.0-3.5\end{array}$ & $\begin{array}{c}11.9 \\
7.8 \\
10.0 \\
630 \\
111 \\
149 \\
1.11 \\
.2\end{array}$ & $\begin{array}{r}7.6 \\
.6 \\
2.1 \\
2,360 \\
65 \\
147 \\
2.17 \\
.3\end{array}$ \\
\hline
\end{tabular}

SPECIES INFORMATION

Refer to Meister (1912), Boyer (1927a), and Patrick and Reimer (1966). 


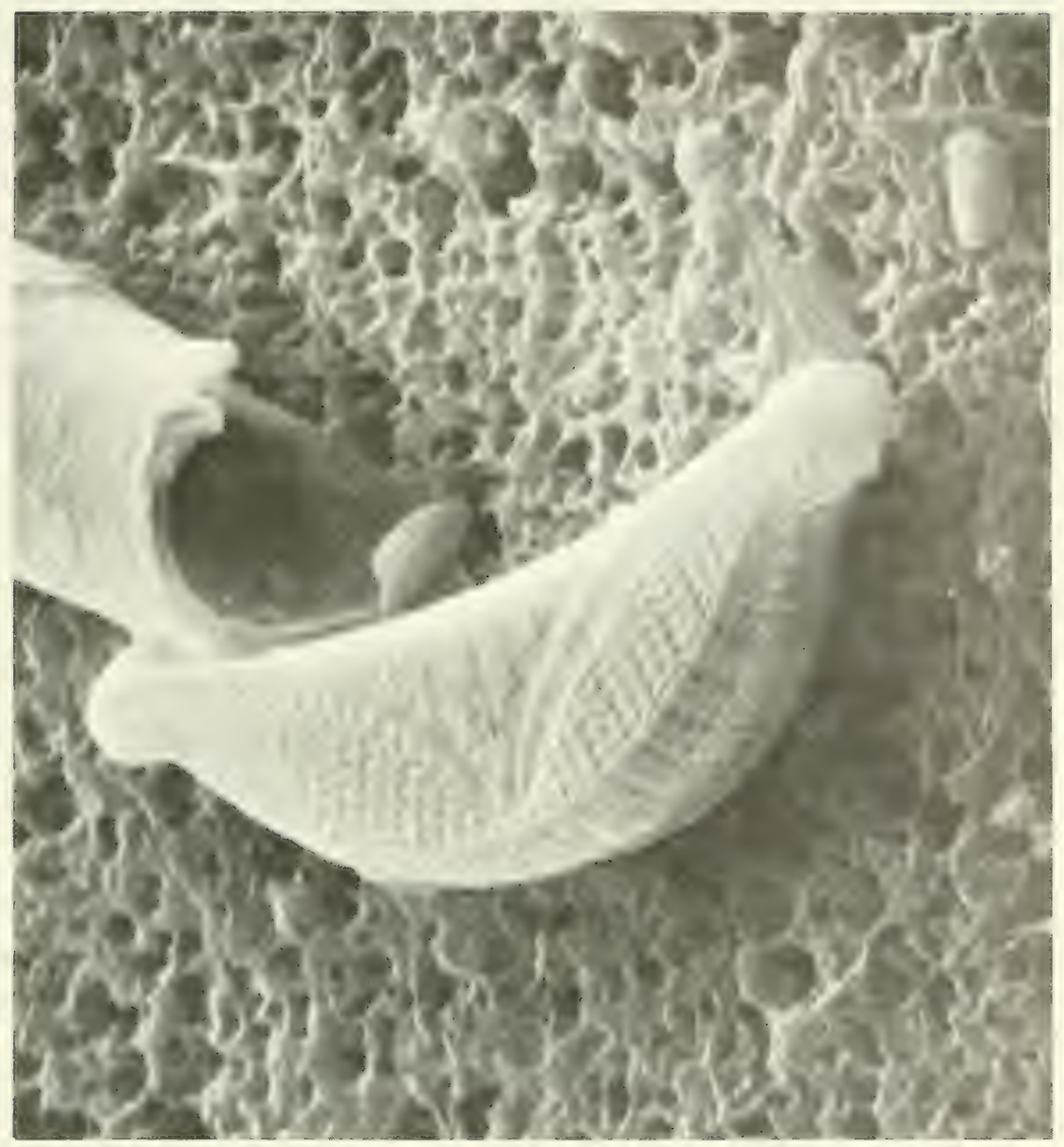

FIGURE 31. - Scanning electronmicrograph of Epithemia. 
Division Chrysophyta

Class Bacillariophyceae

Order Pennales

Family Eunotiaceae

GENUS EUNOTIA Ehrenberg, 1837 (fig. 32)

\section{MORPHOLOGY}

Cells are solitary or joined valve to valve into chains. They are free floating or epiphytic. Cells are rectangular, linear, or tabular in girdle view. Both girdles and valves are strongly ornamented, generally with intercalary bands. Valves are arcuate having similar poles and dissimilar margins. The concave side is regular; the convex side is inflated slightly near the poles and is regular or undulate. A short raphe extends from evident polar nodules diagonally to the concave side. There are no central nodule, costae, nor septae. Two chromatophores are laminate.

\section{REPRODUCTION}

A single auxospore is formed by the conjugation of protoplasts from 2 approximate cells.

\section{OCCURRENCE}

The genus is found commonly in bodies of soft water and in slowly moving waters. They are frequently found in oligotrophic or dystrophic waters (Patrick and Reimer, 1966).

ENVIRONMENTAL CONDITIONS

\begin{tabular}{|c|c|c|c|}
\hline & Range & Mean & $\begin{array}{l}\text { Standard } \\
\text { deviation }\end{array}$ \\
\hline 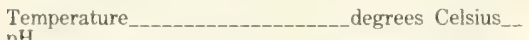 & $0.0-\quad 31.0$ & 14.2 & 8.2 \\
\hline & $3.4-\quad 8.7$ & & .9 \\
\hline Dissolved oxygen________miligrams per liter & $.8-15.2$ & $\begin{array}{r}9.1 \\
283\end{array}$ & 2.4 \\
\hline & $\begin{array}{rr}23 & -45,500 \\
0 & -\end{array}$ & 283 & 1,816 \\
\hline Total alkalinity___________miligrams per liter _- & $\begin{array}{l}-330 \\
-\quad 680\end{array}$ & 64 & $\begin{array}{r}58 \\
101\end{array}$ \\
\hline Total nitrogen & $06-$ & 92 & 101.79 \\
\hline Total phosphorus & $.0-$ & .1 & .2 \\
\hline
\end{tabular}

\section{SPECIES INFORMATION}

Refer to Boyer (1927a) and Patrick and Reimer (1966). 


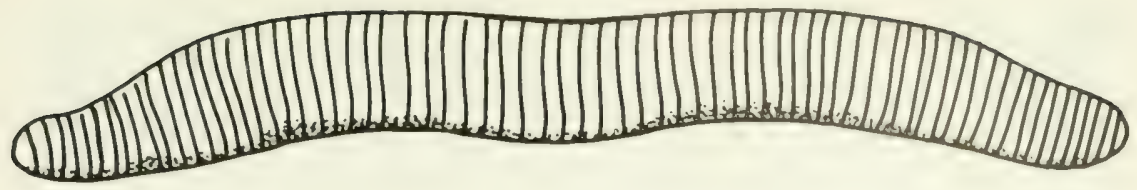

Figure 32.-Drawing of Eunotia. 
Division Chrysophyta

Class Bacillariophyceae

Order Pennales

Family Fragilariaceae

GENUS FRAGILARIA Lyngbye, 1819; emend., Rabenhorst, 1864 (fig. 33)

\section{MORPHOLOGY}

Cells are linear to fusiform, bilaterally symmetrical, commonly attenuated at the poles, sometimes capitate, and often medially inflated. Cells are rectangular in girdle view and have 0,1 , or 2 intercalary bands. They are united into free-floating or sessile colonies, which are generally zigzag chains but sometimes are flat, stellate colonies. The pseudoraphe is narrow and indistinct or broad and prominent. Transverse striae or punctae are present. Chromatophores are numerous small discoid bodies or 1 to 4 laminate plates.

\section{REPRODUCTION}

A single auxospore is formed within a cell.

\section{OCCURRENCE}

Fragilaria is widely distributed. It generally is indicative of alkaline waters of moderate conductivity. The genus is found in the littoral zone, as well as in the euplankton (Patrick and Reimer, 1966).

ENVIRONMENTAL CONDITIONS

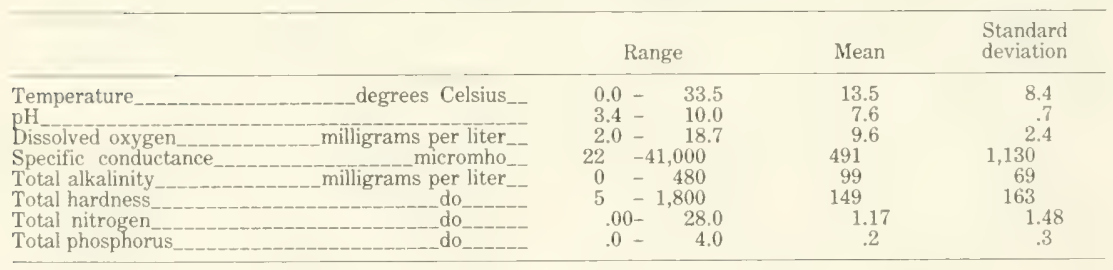

\section{SPECIES INFORMATION}

Refer to Boyer (1927a) and Patrick and Reimer (1966). 


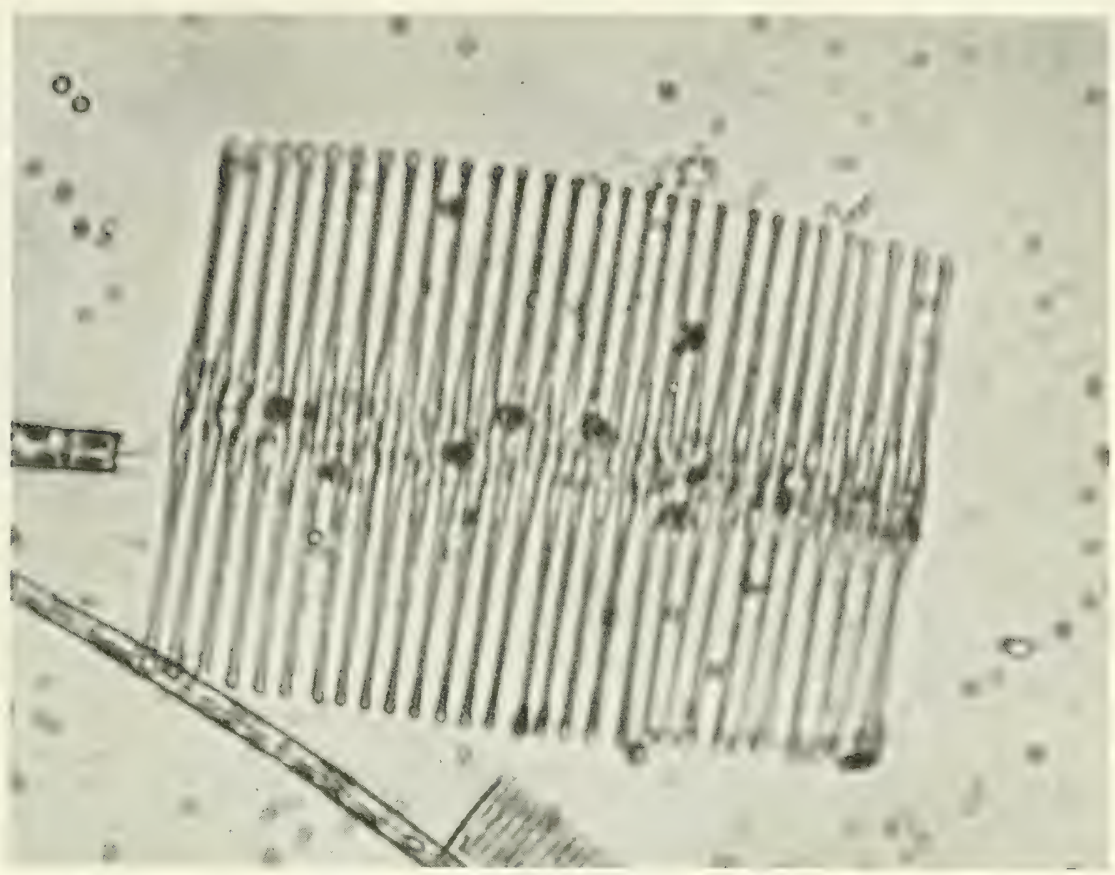

FIgURE 33, - Photomicrograph of Fragilaria. 


\section{Division Chrysophyta}

Class Bacillariophyceae

Order Pennales

Family Gomphonemataceae

GENUS GOMPHONEMA Agardh, 1824 (fig. 34)

\section{MORPHOLOGY}

Cells are commonlyy epiphytic on the ends of dichotomously branched gelatinous stalks. They are sometimes sessile or solitary and free floating. Cells are transversely asymmetrical in both valve and girdle views. Cells are straight, lanceolate, or clavate. One pole is capitate or broader than the other. Intercalary bands are lacking. The raphe is straight and central and polar nodules are conspicuous. Striations are strictly transverse or somewhat radial. The chromatophore is a single, lobed plate.

\section{REPRODUCTION}

The protoplasts of 2 cells each form 2 gametes, which unite to form 2 auxospores.

\section{OCCURRENCE}

The alga is widely distributed. Freshwater species are generally epiphytic, but they occur commonly in the euplankton and tychoplankton.

ENVIRONMENTAL CONDITIONS

\begin{tabular}{|c|c|c|c|}
\hline & Range & Mean & $\begin{array}{l}\text { Standard } \\
\text { deviation }\end{array}$ \\
\hline Temperature & $0.0-\quad 36.0$ & 13.0 & 8.3 \\
\hline $\mathrm{pH}_{\text {Dissolved oxygen }}$ & $4.3-10.0$ & 7.6 & .7 \\
\hline & $12^{.8}-37,400$ & 574 & $1.260^{2.4}$ \\
\hline Total alkalinity & $0-491$ & 105 & 80 \\
\hline Total hardness & $4-1,800$ & 171 & 203 \\
\hline Total nitrogen & $.00-\quad 32.0$ & 1.43 & 1.93 \\
\hline Total phosphorus & $.0-$ & .2 & .4 \\
\hline
\end{tabular}

\section{SPECIES INFORMATION}

Refer to Boyer (1927a). 
DESCRIPTION OF THE GENERA

81

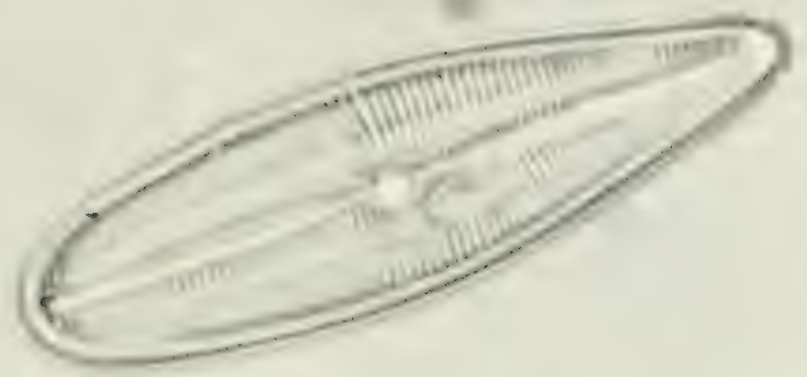

FIGURE 34. -Photomicrograph of Gomphonema. 
Division Chrysophyta

Class Bacillariophyceae

Order Pennales

Family Naviculaceae

GENUS GYROSIGMA Hassall, 1845; emend., Cleve, 1894 (fig. $35)$

\section{MORPHOLOGY}

Cells generally are solitary and free floating, sometimes in gelatinous tubes. They are elliptical to lanceolate in girdle view. Cells are sigmoid in outline and generally attenuated toward the acute or broadly rounded poles. Intercalary bands and septa are lacking. The sigmoid raphe has small central and polar nodules. Transverse striations cross longitudinal striations at right angles. There are two chromatophores, which are smooth or irregularly shaped plates.

\section{REPRODUCTION}

The protoplasts of 2 approximate cells each form 2 gametes. Conjugation results in the formation of 2 auxospores.

\section{OCCURRENCE}

The genus is widely distributed. It generally is indicative of alkaline waters. Some species can tolerate brackish conditions.

ENVIRONMENTAL CONDITIONS

\begin{tabular}{|c|c|c|c|}
\hline & Range & Mean & $\begin{array}{l}\text { Standard } \\
\text { deviation }\end{array}$ \\
\hline Temperature_________________degrees Celsius__- & $\begin{array}{r}0.0-\quad 34.0 \\
43-\quad 9.0\end{array}$ & $\begin{array}{r}16.3 \\
7.6\end{array}$ & 8.7 \\
\hline Dissolved oxygen & $\begin{array}{r}4.3-9.0 \\
1.1-\quad 19.3\end{array}$ & $\begin{array}{l}7.6 \\
9.0\end{array}$ & 2.3 \\
\hline Specific conductance ___ micromho__ & $32-47,800$ & 1,310 & 3,610 \\
\hline Total alkalinity__._. milligrams per liter & $-\quad 386$ & 129 & 80 \\
\hline Total hardness & $-2,000$ & 262 & 305 \\
\hline Total nitrogen & $.06-\quad 27.0$ & 1.84 & 2.15 \\
\hline Total phosphorus & $.0-$ & .3 & .4 \\
\hline
\end{tabular}

\section{SPECIES INFORMATION}

Refer to Boyer (1927a) and Patrick and Reimer (1966). 


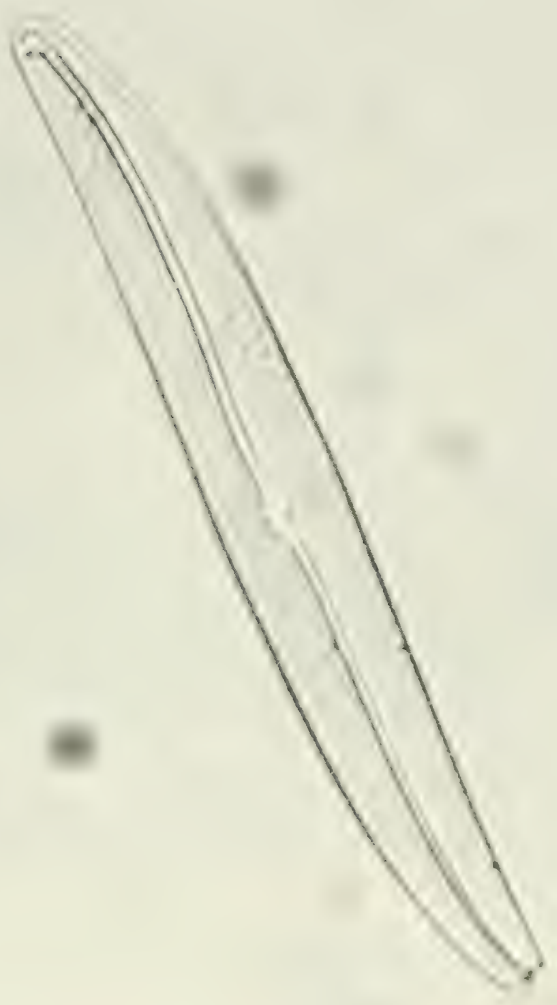

FIGURE 35. - Photomicrograph of Gyrosigma. 
Division Chrysophyta

Class Bacillariophyceae

Order Centrales

Family Coscinodiscaceae

GENUS MELOSIRA Agardh, 1824 (fig. 36)

\section{MORPHOLOGY}

Cells are cylindrical and united into long filaments. Cell length is greater than width. Valve view is circular. Valves may be flat or convex. If convex, they generally have a marginal ring of denticulations that unite cells into filaments. Girdles may or may not have a sulcus. If a sulcus is present, part of the girdle below the sulcus is smooth; if a sulcus is absent, the entire girdle is ornamented. Crowded chromatophores are numerous, small, and dise shaped.

\section{REPRODUCTION}

A single auxospore is formed within a cell. Microspores were observed by Schmidt (1923) in Melosira varians.

\section{OCCURRENCE}

Melosira, a filamentous centric alga, is one of the most ubiquitous of the algal genera. It is widely distributed in all types of waters; however, some species are indicative of particular environmental conditions.

ENVIRONMENTAL CONDITIONS

\begin{tabular}{|c|c|c|c|}
\hline & Range & Mean & $\begin{array}{l}\text { Standard } \\
\text { deviation }\end{array}$ \\
\hline $\begin{array}{l}\text { Temperature____________egrees Celsius__- } \\
\mathrm{pH}\end{array}$ & $\begin{array}{l}0.0-\quad 34.0 \\
3.4-\quad 10.0\end{array}$ & $\begin{array}{r}16.4 \\
7.6\end{array}$ & 8.4 \\
\hline bissolved oxygen & $.1-$ & 9.0 & 2.4 \\
\hline Specific conductance & $10-49,000$ & 524 & 1,296 \\
\hline Total alkalinity________ & $0-378$ & 100 & 72 \\
\hline Total hardness & $4-2,000$ & 155 & 165 \\
\hline Total nitrogen & $.00-\quad 41.0$ & 1.43 & 1.70 \\
\hline Total phosphorus & $.0-$ & .2 & .3 \\
\hline
\end{tabular}

\section{SPECIES INFORMATION}

Refer to Boyer (1927a). 


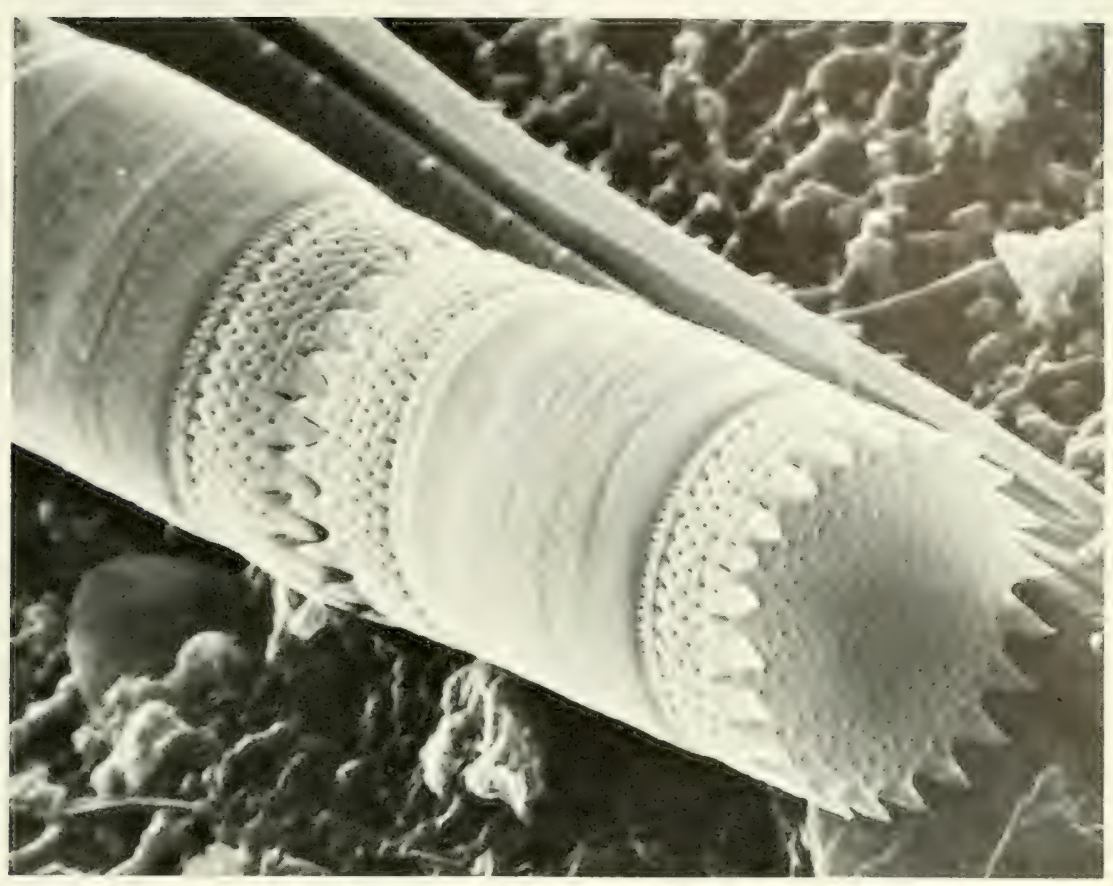

Figure 36. - Scanning electronmicrograph of Melosira. 
Division Chrysophyta

Class Bacillariophyceae

Order Pennales

Family Naviculaceae

GENUS NAVICULA Bory, 1822 (fig. 37)

\section{MORPHOLOGY}

Cells generally are solitary and free floating but may be aggregated into irregularly radiating clusters. Cells are symmetrical, elongate, and generally attenuated toward the poles. Apices are capitate, rounded, or rostrate. Intercalary bands are lacking. The raphe is straight and central, and polar nodules are expanded. Striations are transverse, sometimes medially radiate. There are 2 (most commonly) or 4 to 8 laminate chromatophores.

\section{REPRODUCTION}

Two approximate cells each form 2 gametes. Union of gametes results in 2 auxospores.

\section{OCCURRENCE}

The genus has a widespread distribution and is found in all types of surface waters. Some species are indicative of particular environmental conditions (Patrick, 1948, 1973). According to information included in this report, Navicula is the second most commonly occurring genus in the phytoplankton of the United States.

ENVIRONMENTAL CONDITIONS

\begin{tabular}{|c|c|c|c|}
\hline & Range & Mean & $\begin{array}{l}\text { Standard } \\
\text { deviation }\end{array}$ \\
\hline Temperature & $0.0-\quad 37.0$ & 15.2 & 8.6 \\
\hline $\begin{array}{l}\text { pH } \\
\text { Dissolved oxygen }\end{array}$ & $\begin{array}{r}3.4- \\
.1-\end{array}$ & $\begin{array}{l}7.0 \\
9.2\end{array}$ & 2.4 \\
\hline Specific conductance & $10-49,800$ & 940 & 2,960 \\
\hline Total alkalinity & $-\quad 500$ & 111 & 81 \\
\hline Total hardness & $3-2,000$ & 205 & 256 \\
\hline$-3 \mathrm{do}$ & $.00-$ & 1.52 & 2.02 \\
\hline Total phosphorus & 0 - & .2 & .4 \\
\hline
\end{tabular}

\section{SPECIES INFORMATION}

Refer to Boyer (1927a), Cleve (1895), and Patrick and Reimer (1966). 


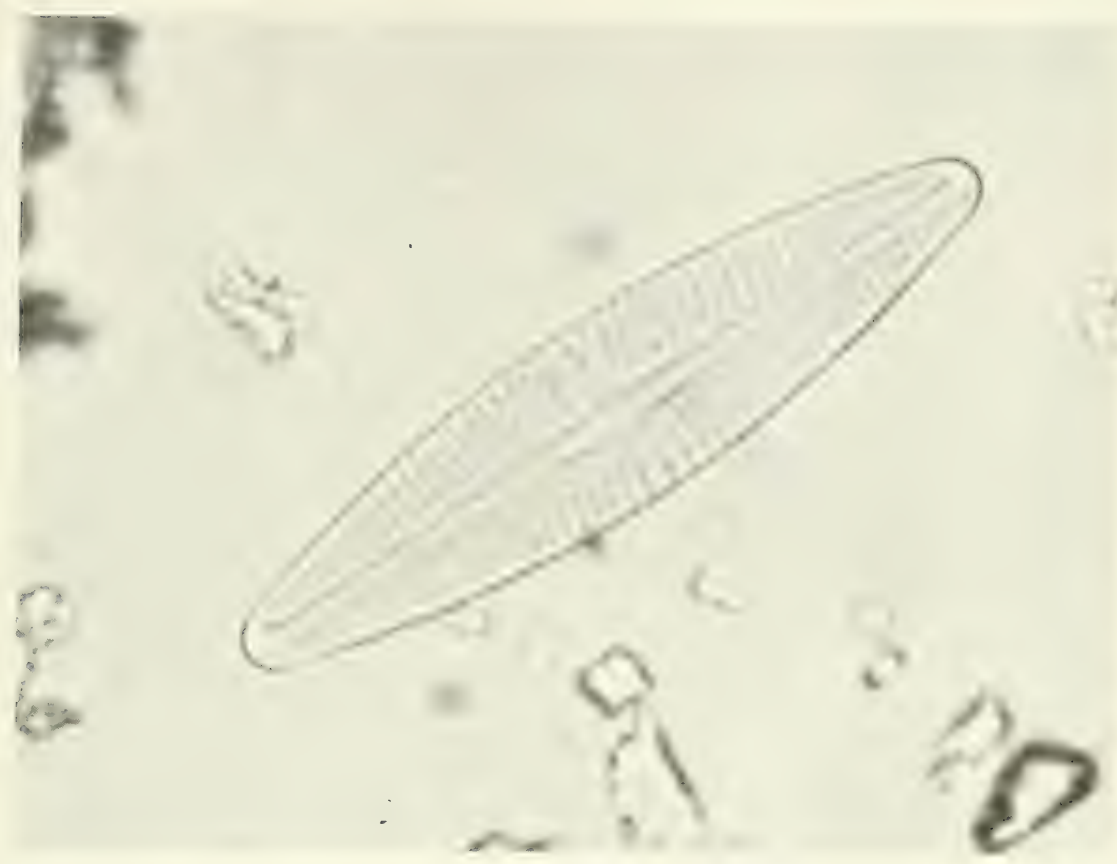

FIgURE 37.-Photomicrograph of Navicula. 
Division Chrysophyta

Class Bacillariophyceae

Order Pennales

Family Nitzschiaceae

GENUS NITZSCHIA Hassall, 1845 (fig. 38)

\section{MORPHOLOGY}

Cells are solitary and free floating or densely clustered in unbranched gelatinous tubes. They are generally elongate and extremely varied in outline, having somewhat attenuated poles. Valves are longitudinally asymmetrical. Keeled margin of one valve faces unkeeled margin of other valve. The raphe lies within the keel and has small central and polar nodules. A rapheal fissure has a uniseriate row of conspicuous circular pores (carinal dots) opening toward the interior of the cell. Striae or punctae are transverse. Two chromatophores on same girdle face are axial.

\section{REPRODUCTION}

Protoplasts of 2 approximate cells each form 2 gametes. Union of gametes forms 2 auxospores.

\section{OCGURRENCE}

The genus has a widespread distribution and is found in all types of waters. Some species are indicative of particular environmental conditions (Patrick, 1948, 1973). According to information included in this report, Nitzschia is the most commonly occurring genus in the phytoplankton of the United States.

ENVIRONMENTAL CONDITIONS

\begin{tabular}{|c|c|c|c|}
\hline & Range & Mean & $\begin{array}{l}\text { Standard } \\
\text { deviation }\end{array}$ \\
\hline $\begin{array}{l}\text { Temperature _... } \\
\text { pH }\end{array}$ & $\begin{array}{l}0.0-\quad 37.0 \\
3.4-\quad 10.0\end{array}$ & 15.6 & 8.8 \\
\hline Dissolved oxygen_-_._-_ milligrams per liter & 22.0 & 9.1 & 2.5 \\
\hline _._. micromho_. & $10^{.2}-49,800$ & 966 & 2,930 \\
\hline Total alkalinity & $0-500$ & 115 & 81 \\
\hline $\begin{array}{l}\text { Total hardness } \\
\text { Total nitrogen }\end{array}$ & $3-2,000$ & 214 & 259 \\
\hline Total phosphorus & $0=$ & $\begin{array}{l}1.04 \\
.2\end{array}$ & .4 \\
\hline
\end{tabular}

\section{SPECIES INFORMATION}

Refer to Boyer (1927a). 


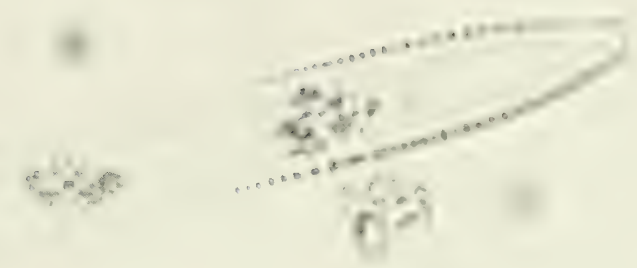

FIGURE 38. - Photomicrograph of Nitzschia. 
Division Chrysophyta

Class Bacillariophyceae

Order Pennales

Family Naviculaceae

GENUS PINNULARIA Ehrenberg, 1840 (fig. 39)

\section{MORPHOLOGY}

Solitary, free-floating cells are symmetrical, generally straight, and have broadly rounded poles. Girdle view is rectangular; axial view is generally broad and expanded polarly and medially. Girdles are smooth. Intercalary bands are lacking. The raphe is complicated and straight or sigmoid. Costae are tubular openings in the valve wall. Two longitudinal lines are visible in the costae part of the valve. There are 2 laminate chromatophores.

\section{REPRODUCTION}

Two auxospores are formed by the union of 2 gametes from each of 2 approximate cells.

\section{OCCURRENCE}

The genus is widely distributed. It generally is indicative of calm or slowly moving, slightly acid waters having low mineral content. Sometimes Pinnularia is present in abundance in semipermanent or permanent pools of soft-water localities (Smith, 1950).

\section{ENVIRONMENTAL CONDITIONS}

\begin{tabular}{|c|c|c|c|}
\hline & Range & Mean & $\begin{array}{l}\text { Standard } \\
\text { deviation }\end{array}$ \\
\hline Temperature _-_____________egrees Celsius__ & $\begin{array}{rr}0.0- & 33.5 \\
3.4- & 8.9\end{array}$ & $\begin{array}{r}15.8 \\
7.3\end{array}$ & $\begin{array}{r}8.2 \\
.9\end{array}$ \\
\hline milligrams per liter & $1.3-$ & 8.9 & 2.1 \\
\hline Specific conductance & $20-43,400$ & 662 & 2,060 \\
\hline Total alkalinity & $-\quad 430$ & 91 & 83 \\
\hline Total hardness _-__ & $3-1,700$ & 153 & 213 \\
\hline Total nitrogen & $.09-$ & 1.48 & 2.24 \\
\hline Total phosphorus & $.0-$ & .2 & .4 \\
\hline
\end{tabular}

\section{SPECIES INFORMATION}

Refer to Boyer (1927a) and Patrick and Reimer (1966). 
DESCRIPTION OF THE GENERA

91

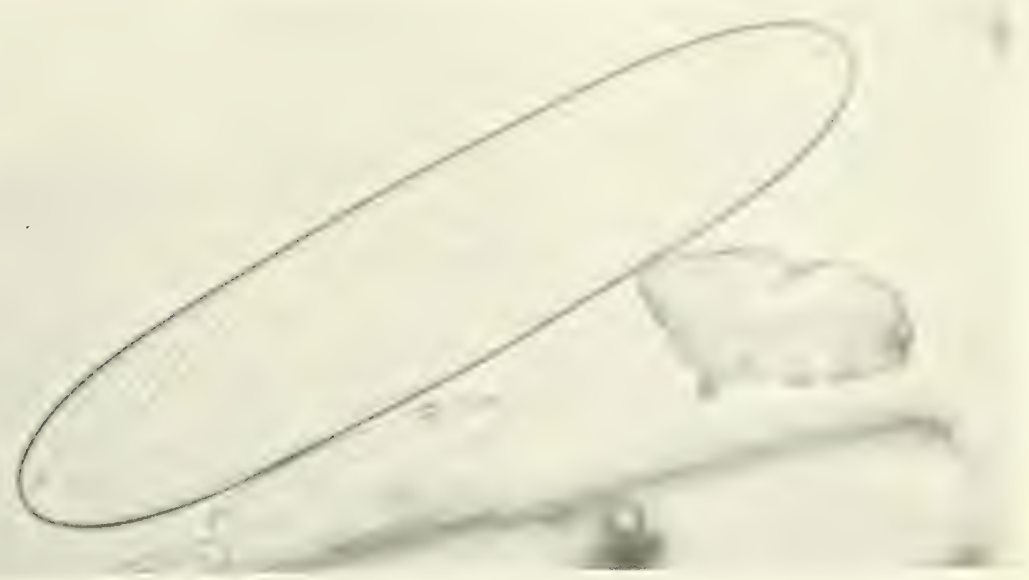

Figure 39. - Photomicrograph of Pinnularia. 
Division Chrysophyta

Class Bacillariophyceae

Order Pennales

Family Achnanthaceae

GENUS RHOICOSPHENIA Grunow, 1860 (fig. 40)

\section{MORPHOLOGY}

Wedge-shaped cells are sessile and attached at the narrower end to a more or less branching system of gelatinous stalks affixed to macrophytes. Cells are $4-8 \mu \mathrm{m}$ in diameter and $12-75 \mu \mathrm{m}$ long. The hypotheca is concave and contains a median raphe and nodules. The epitheca is convex and contains a median pseudoraphe. In girdle view, cells are cuneate and curved in the longitudinal axis. Intercalary bands are unornamented between striated girdles. Other striations are transverse. There are 2 longitudinal septa. A single chromatophore is laminate.

\section{REPRODUCTION}

Conjugating sister cells form a single auxospore.

\section{OCCURRENCE}

The alga has a widespread distribution. The single species, Rhoicosphenia curvata, is found commonly in flowing alkaline waters. It is generally intolerant of saline conditions.

ENVIRONMENTAL CONDITIONS

\begin{tabular}{|c|c|c|c|}
\hline & Range & Mean & $\begin{array}{l}\text { Standard } \\
\text { deviation }\end{array}$ \\
\hline ______egrees Celsius___ & $0.0-$ & 12.6 & 7.8 \\
\hline 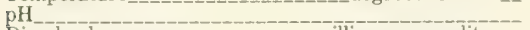 & $5.2-$ & 7.8 & .6 \\
\hline Dissolved oxygen________ligrams per liter & $3.4-16.6$ & 10.0 & 2.2 \\
\hline Specific conductance & $10-10,000$ & 492 & 671 \\
\hline Total alkalinity & -480 & 109 & 74 \\
\hline Total hardness & $-1,600$ & 160 & 152 \\
\hline Total nitrogen.... & $.00-\quad 32.0$ & 1.43 & 1.91 \\
\hline Total phosphorus & $.0-$ & .2 & .3 \\
\hline
\end{tabular}

SPECIES INFORMATION

Refer to Boyer (1927a) and Patrick and Reimer (1966). 


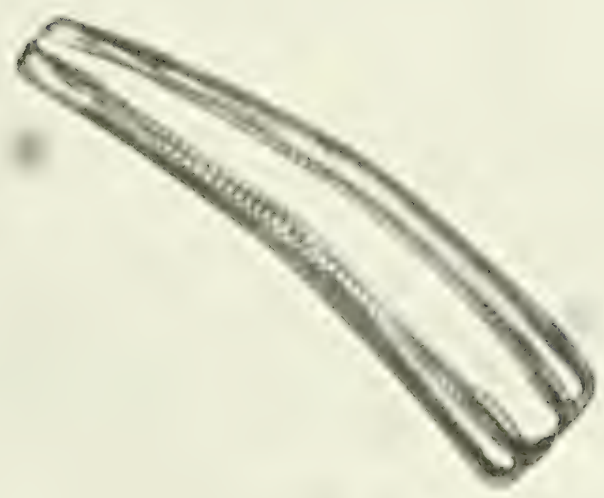

FIGURE 40.-Photomicrograph of Rhoicosphenia. 
Division Chrysophyta

Class Bacillariophyceae

Order Centrales

Family Coscinodiscaceae

GENUS STEPHANODISCUS Ehrenberg, 1845 (fig. 41)

\section{MORPHOLOGY}

Solitary, free-floating cells are discoid. Valves are circular, radially punctate, and have short marginal spines. Outer areas of punctae are in multiseriate rows; each row becomes uniseriate toward the center. Small central area is irregularly punctate. Girdles are slightly undulate and smooth and lack intercalary bands. There are 1 or 2 irregular or numerous discoid chromatophores.

\section{REPRODUCTION}

A single auxospore is formed within a cell.

\section{OCCURRENCE}

This is a widely distributed diatom. It is an insignificant component of algal communities indicating eutrophic conditions.

ENVIRONMENTAL CONDITIONS

\begin{tabular}{|c|c|c|c|}
\hline & Range & Mean & $\begin{array}{l}\text { Standard } \\
\text { deviation }\end{array}$ \\
\hline _______________egrees Celsius___ & $0.0-$ & 16.1 & 8.6 \\
\hline 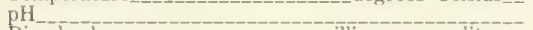 & $4.6-$ & 7.8 & .6 \\
\hline milligrams per liter & $.1-$ & 9.3 & 2.4 \\
\hline Specific conductance & $10-10,800$ & 533 & 879 \\
\hline Total alkalinity ___ _ _ _ milligrams per liter & -470 & 113 & 64 \\
\hline Total hardness_... & $-1,800$ & 171 & 165 \\
\hline Total nitrogen & $.00-\quad 24.0$ & 1.49 & 1.89 \\
\hline Total phosphorus & $.0-$ & .2 & .3 \\
\hline
\end{tabular}

SPECIES INFORMATION

Refer to Boyer (1927a) and Skvortzow (1937). 


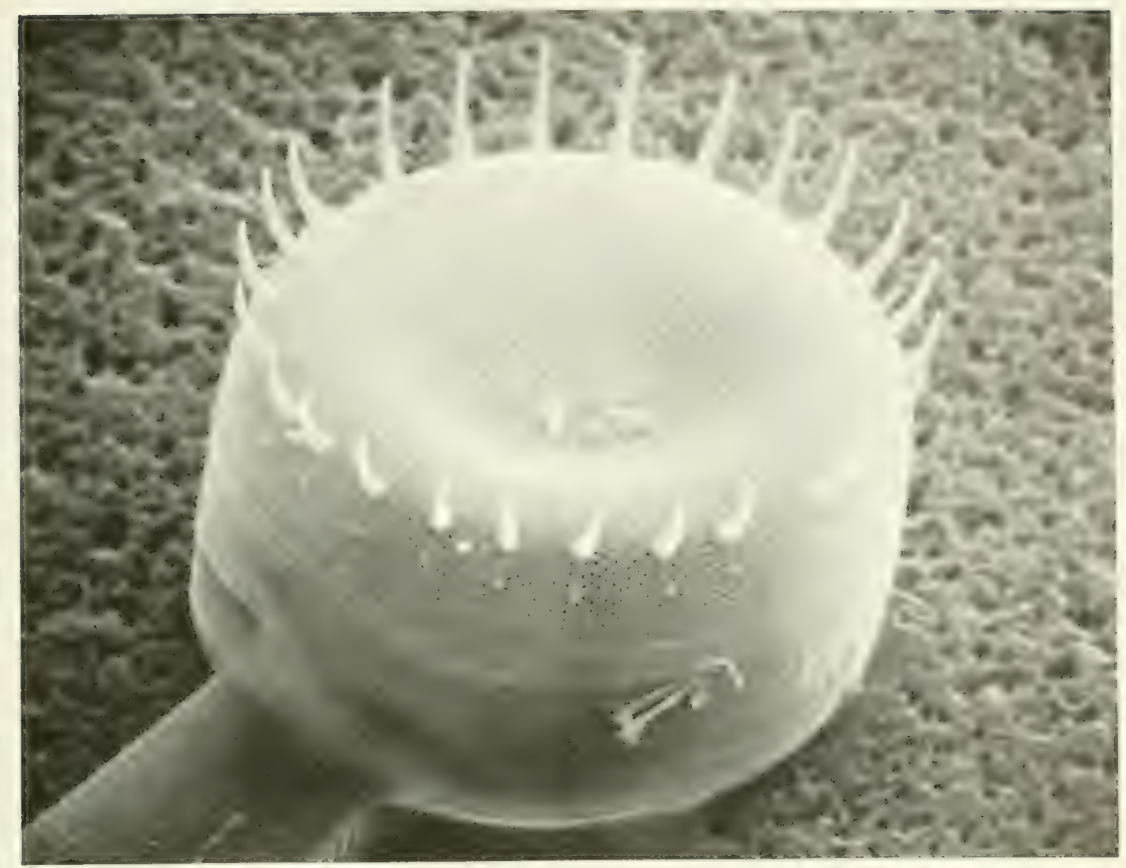

FIGURE 41. - Scanning electronmicrograph of Stephanodiscus. 
Division Chrysophyta

Class Bacillariophyceae

Order Pennales

Family Surirellaceae

GENUS SURIRELLA Turpin, 1828 (fig. 42)

\section{MORPHOLOGY}

Cells generally are solitary and free floating, are linear elliptical or ovate in valve view, have broadly rounded to subacute poles, and are rectangular naviculoid, cuneate, or sigmoid in girdle view. Girdles are smooth. Entire valve face may be in 1 plane, or it may be slightly spirally twisted. Each valve margin is keeled and contains a raphe having central and polar nodules. Parallel costae are transverse. Fine striae extend across valve face and are interrupted by a median longitudinal pseudoraphe. One chromatophore is present.

\section{REPRODUCTION}

Protoplasts from 2 cells lying end to end unite to form an auxospore.

\section{OCCURRENCE}

The alga has a widespread distribution.

ENVIRONMENTAL CONDITIONS

\begin{tabular}{|c|c|c|c|}
\hline & Range & Mean & $\begin{array}{l}\text { Standard } \\
\text { deviation }\end{array}$ \\
\hline $\begin{array}{l}\text { Temperature ________degrees Celsius _- } \\
\mathrm{pH}\end{array}$ & $\begin{array}{l}0.0-37.0 \\
3.7-\quad 10.0\end{array}$ & $\begin{array}{r}12.8 \\
7.7\end{array}$ & $\begin{array}{r}8.5 \\
.6\end{array}$ \\
\hline bissolved oxygen___ milligrams per liter & $2.5-18.4$ & 9.7 & 2.3 \\
\hline Specific conductance & $29-35,000$ & 985 & 1,910 \\
\hline milligrams per liter_- & $0-440$ & 137 & 83 \\
\hline Total hardness & $6-1,800$ & 260 & 275 \\
\hline - & $.01-\quad 41.0$ & 2.10 & 2.60 \\
\hline Total phosphorus & $.0-$ & .3 & .4 \\
\hline
\end{tabular}

\section{SPECIES INFORMATION}

Refer to Boyer (1927a). 


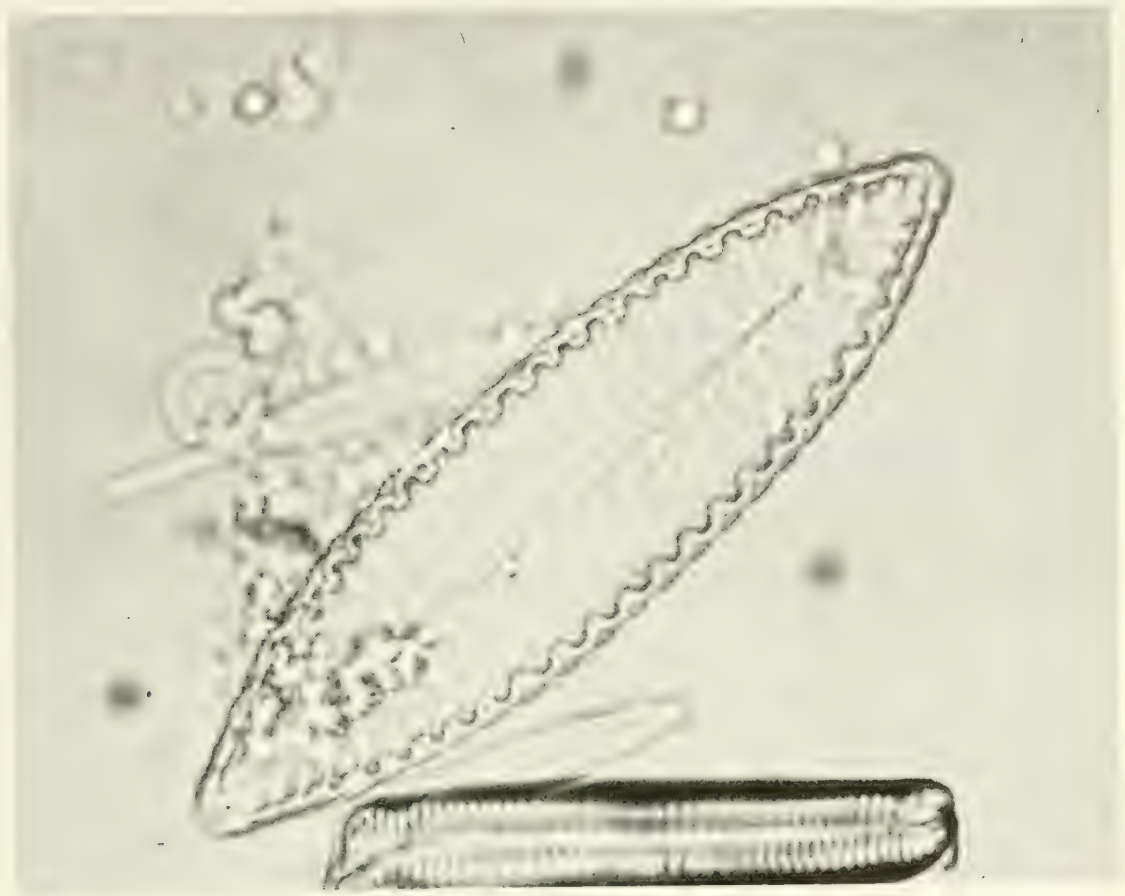

FIGURE 42. - Photomicrograph of Surirella. 


\section{Division Chrysophyta}

Class Bacillariophyceae

Order Pennales

Family Fragilariaceae

GENUS SYNEDRA Ehrenberg, 1830 (fig. 43)

\section{MORPHOLOGY}

Cells are narrow and generally very elongate. They are solitary or in tufted, fan-shaped, or radiating colonies. They are free floating or epiphytic, sessile, or contained in a gelatinous stalk. Cells are linear to lanceolate, generally straight but sometimes slightly curved. Poles may be attentuated and sometimes capitate. Transverse striae are lateral to a conspicuous narrow pseudoraphe. The central area may be smooth or striated. The two chromatophores are discoid.

\section{REPRODUCTION}

Either 1 or 2 auxospores may be formed within a cell. A "regeneration" cell, which increases the size of the cell, has been observed by Gemeinhardt (1926).

\section{OCCURRENGE}

Synedra is widely distributed and is found in all types of waters. The commonly occurring species generally occur in circumneutral water of moderate to high conductivity, including brackish water. The genus is generally indicative of mesotrophic to eutrophic conditions. It is found in the euplankton, tychoplankton, and periphyton.

ENVIRONMENTAL CONDITIONS

\begin{tabular}{|c|c|c|c|}
\hline & Range & Mean & $\begin{array}{l}\text { Standard } \\
\text { deviation }\end{array}$ \\
\hline 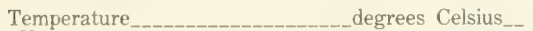 & $0.0-$ & 14.5 & 8.8 \\
\hline 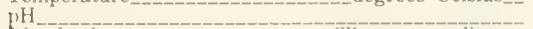 & $3.7-$ & 7.6 & .7 \\
\hline Dissolved oxygen_____________milligrams per liter & $.2-$ & 9.4 & 2.4 \\
\hline Specific conductance & $10^{\circ}-49,800$ & 671 & 2,050 \\
\hline Total alkalinity & -491 & 105 & 79 \\
\hline Total hardness & $-1,900$ & 180 & 223 \\
\hline - do & $.00-\quad 41.0$ & 1.38 & 1.81 \\
\hline Total phosphorus & $.0-$ & .2 & .3 \\
\hline
\end{tabular}

\section{SPECIES INFORMATION}

Refer to Boyer (1927a) and Patrick and Reimer (1966). 
Figure 43.-Drawing of Synedra. 
Division Chrysophyta

Class Bacillariophyceae

Order Pennales

Family Tabellariaceae

GENUS TABELLARIA Ehrenberg, 1840 (fig. 44)

\section{MORPHOLOGY}

Cells generally are joined into zigzag chains but sometimes into stellate colonies. They are free floating. Valves have numerous intercalary bands between the girdles. Between the girdles and intercalary bands are longitudinal septa penetrating to the center of the cell. Valves are elongate and have an evident, medial inflation. They are slightly inflated at the poles. There is a narrow pseudoraphe that has lateral, transverse striae. Chromatophores are numerous small discs.

\section{REPRODUCTION}

Either 1 (Geitler, 1927) or 2 (Schütt, 1896) auxospores may form within a single cell.

\section{OGCURRENCE}

The genus is of widespread distribution in the euplankton. The most common species, Tabellaria fenestrata, is indicative of mesotrophic to eutrophic conditions. The genus generally occurs in circumneutral, shallow waters.

ENVIRONMENTAL CONDITIONS

\begin{tabular}{|c|c|c|c|}
\hline & Range & Mean & $\begin{array}{l}\text { Standard } \\
\text { deviation }\end{array}$ \\
\hline Temperature____________________degrees Celsius__ & $0.0-31.0$ & 12.4 & 8.1 \\
\hline 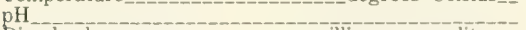 & $3.9-\quad 8.9$ & 7.3 & .7 \\
\hline milligrams per liter & $1.2-$ & 10.0 & 2.4 \\
\hline Specific conductance & $16-6,860$ & 221 & 391 \\
\hline Total alkalinity______ milligrams per liter & -320 & 64 & 58 \\
\hline do & $5 \quad-1,500$ & 87 & 121 \\
\hline Total nitrogen & $.01-\quad 11.0$ & .87 & 1.08 \\
\hline 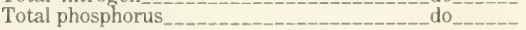 & $.0-$ & 1 & .2 \\
\hline
\end{tabular}

\section{SPECIES INFORMATION}

Refer to Boyer (1927a) and Patrick and Reimer (1966). 


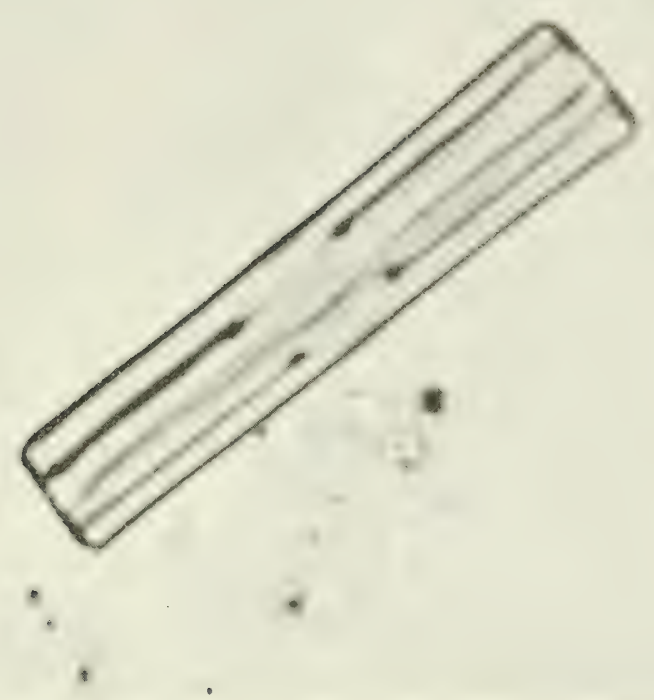

Figure 44.-Photomicrograph of Tabellaria. 
Division Pyrrophyta

Class Dinophyceae

Order Peridiniales

Family Glenodiniaceae

GENUS GLENODINIUM Stein, 1883 (fig. 45)

\section{MORPHOLOGY}

Solitary, motile cells are asymmetrically globose but may be slightly dorsoventrally flattened. The cell is surrounded by a definite number of plates arranged in a specific manner. Cell wall is divided near the center into an apical epitheca and an antapical hypotheca. Epitheca has 2-9 apical, 0-4 anterior intercalary, and 6-12 precingular plates; hypotheca has 5-12 postcingular, 0-2 posterior intercalary, and 1-2 antapical plates. A longitudinal sulcus extends from the girdle into the hypotheca. There are 2 flagella. A prominent eyespot may be present. Numerous chromatophores are brown.

\section{REPRODUCTION}

Reproduction is isogamous by the union of gymnodinoid gametes. Each zygote forms 4 zoospores.

\section{OCCURRENCE}

The genus is generally found in the tychoplankton; however, it can occur in the euplankton. It seems to prefer soft-water conditions.

\section{ENVIRONMENTAL CONDITIONS}

\begin{tabular}{|c|c|c|c|}
\hline & Range & Mean & $\begin{array}{l}\text { Standard } \\
\text { deviation }\end{array}$ \\
\hline ______ngrees Celsius & $0.0-$ & 17.5 & 9.6 \\
\hline pH & $4.6-$ & 7.6 & .7 \\
\hline Dissolved oxygen____._. milligrams per liter & $.1-$ & 8.6 & 3.1 \\
\hline Specific conductance & $11^{-1}-42,100$ & 1,400 & 4,570 \\
\hline Total alkalinity milligrams per liter & $-\quad 477$ & 120 & 80 \\
\hline Total hardness & $-1,700$ & 219 & 248 \\
\hline Total nitrogen & $.00-\quad 11.0$ & 1.26 & 1.17 \\
\hline Total phosphorus & .0 & .1 & .2 \\
\hline
\end{tabular}

\section{SPECIES INFORMATION}

Refer to Schiller (1933) and Prescott (1962). 


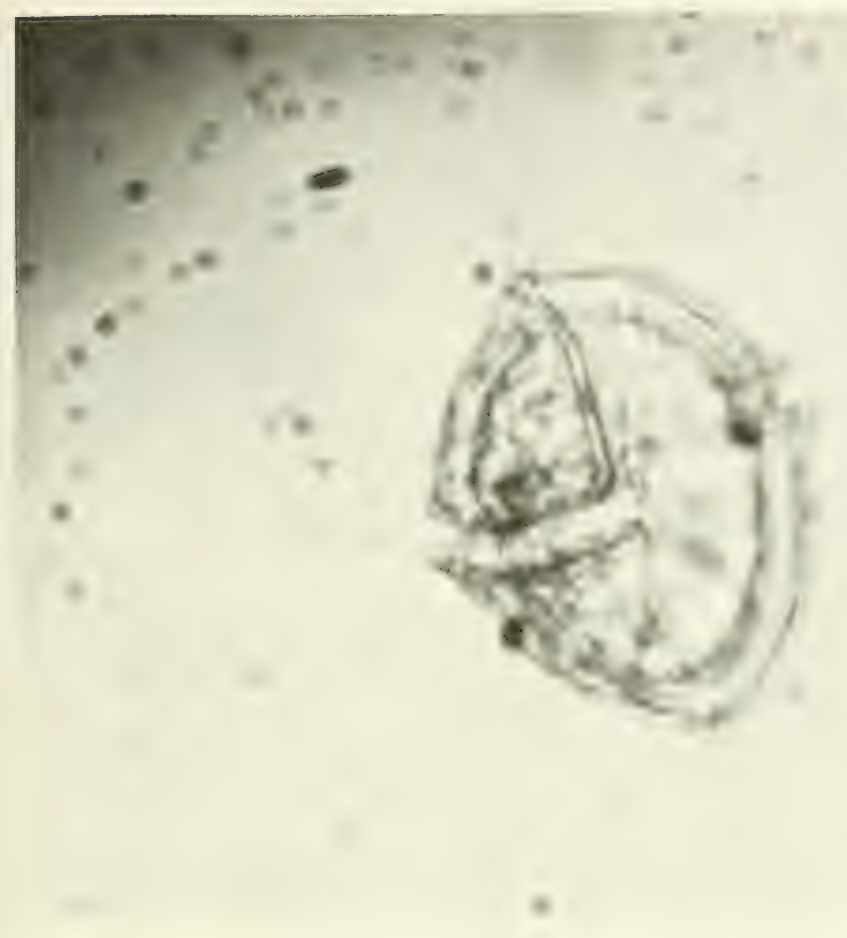

FIGURE 45.-Photomicrograph of Glenodinium. 
Division Pyrrophyta

Class Dinophyceae

Order Peridiniales

Family Peridiniaceae

GENUS PERIDINIUM Ehrenberg, 1830; emend., Stein, 1883 (fig. 46)

\section{MORPHOLOGY}

Solitary, motile cells are spherical, ovoid, or angular and may or may not have short apical and antapical horns. The cell is surrounded by a definite number of plates arranged in a specific manner. Cell wall is divided near the center into an apical epitheca and an antapical hypotheca. Epitheca has 4 apical, 2-3 anterior intercalary, and 7 precingular plates; hypotheca has 5 postcingular and 2 antapical plates. A longitudinal sulcus extends from the girdle into the hypotheca. There are 2 flagella. A prominent eyespot may be present. Numerous chromatophores are brown.

\section{REPRODUCTION}

Aplanospores are formed by division of the protoplast.

\section{OCCURRENCE}

The alga is of widespread distribution in the euplankton and tychoplankton.

\section{ENVIRONMENTAL CONDITIONS}

\begin{tabular}{|c|c|c|c|}
\hline & Range & Mean & $\begin{array}{l}\text { Standard } \\
\text { deviation }\end{array}$ \\
\hline 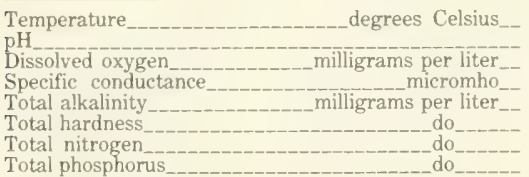 & $\begin{array}{r}0.0-\quad 33.0 \\
4.6-9.6 \\
.8-\quad 18.7 \\
26-30,000 \\
3-477 \\
5-2,000 \\
.05-\quad 13.0 \\
.0-\quad 2.2\end{array}$ & $\begin{array}{c}18.6 \\
7.6 \\
8.5 \\
881 \\
113 \\
197 \\
1.10 \\
.1\end{array}$ & $\begin{array}{r}9.2 \\
.7 \\
2.8 \\
2,480 \\
85 \\
241 \\
1.10 \\
.2\end{array}$ \\
\hline
\end{tabular}

\section{SPECIES INFORMATION}

Refer to Lefèvre (1932) and Prescott (1962). 


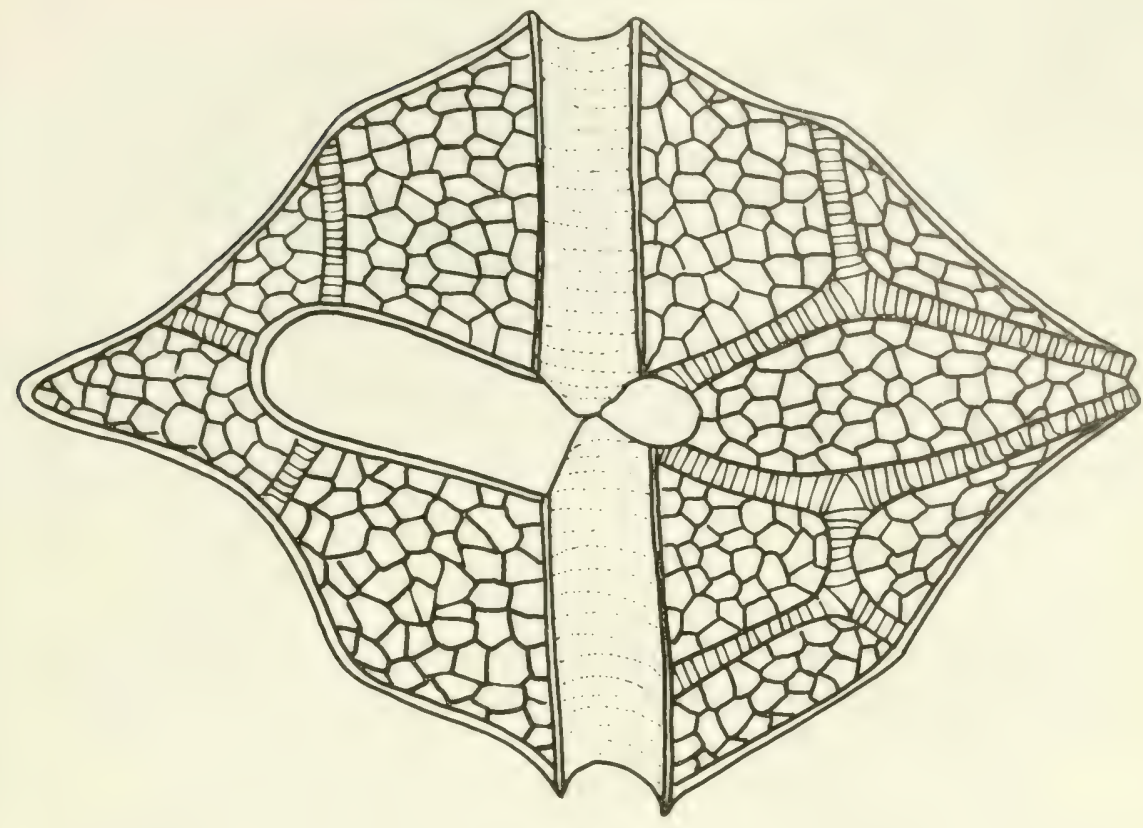

Figure 46. - Drawing of Peridinium. 
Division Cryptophyta

Class Cryptophyceae

Order Cryptomonidales

Family Cryptochrysidaceae

GENUS CHROOMONAS Hansgrirg, 1892 (fig. 47)

\section{MORPHOLOGY}

Solitary, motile cells are compressed. The anterior end is truncated, and the posterior end is rounded. A longitudinal furrow is at the anterior end near the point of insertion of 2 unequal flagella. An eyespot and granules may be present. The single laminate chromatophore is blue green.

\section{REPRODUCTION}

Longitudinal division of the protoplast results in the formation of 2 daughter cells. Rosenberg (1944) observed a palmella stage.

\section{OCCURRENCE}

The alga is common in shallow waters and among algal masses and decaying vegetation (Prescott, 1962).

\section{ENVIRONMENTAL CONDITIONS}

\begin{tabular}{|c|c|c|c|}
\hline & Range & Mean & $\begin{array}{l}\text { Standard } \\
\text { deviation }\end{array}$ \\
\hline _____degrees Celsius__ & $0.0-$ & 16.5 & 9.0 \\
\hline $\mathrm{pH}_{-}$ & $4.3-$ & 7.7 & .7 \\
\hline milligrams per liter & $.1-$ & 8.9 & 2.9 \\
\hline Specific conductance & $21-47,800$ & 1,110 & 4,030 \\
\hline Total alkalinity & -477 & 128 & 82 \\
\hline Total hardness & $-1,700$ & 209 & 198 \\
\hline Total nitrogen & $.01-\quad 24.0$ & 1.25 & 1.73 \\
\hline Total phosphorus & $.0-$ & .1 & .2 \\
\hline
\end{tabular}

\section{SPECIES INFORMATION}

Refer to Lackey (1939), Pascher (1913), and Prescott (1962). 


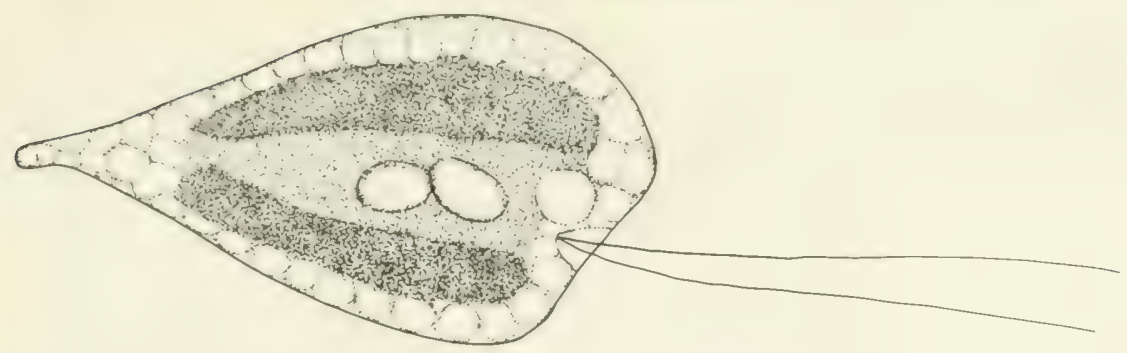

Figure 47.-Drawing of Chroomonas. 
Division Cryptophyta

Class Cryptophyceae

Order Cryptomonidales

Family Cryptomonodaceae

GENUS CRYPTOMONAS Ehrenberg, 1831 (fig. 48)

\section{MORPHOLOGY}

Solitary, free-swimming cells are compressed, somewhat elliptical, and broadly rounded to truncate at the anterior end. Two unequal flagella are inserted into an evident gullet, which may be lined with granular trichoblasts. A contractile vacuole is next to the gullet. The 1 to 2 large chromatophores are yellow to olive green but are sometimes red.

\section{REPRODUCTION}

A mucilage surrounds an immobile stage prior to longitudinal division into 2 daughter cells.

\section{OCCURRENCE}

Cryptomonas is found in the euplankton and tychoplankton.

ENVIRONMENTAL CONDITIONS

\begin{tabular}{|c|c|c|c|}
\hline & Range & Mean & $\begin{array}{l}\text { Standard } \\
\text { deviation }\end{array}$ \\
\hline _degrees Celsius___ & $0.0-$ & 16.3 & 8.8 \\
\hline $\mathrm{pH}_{-}$ & $4.1-$ & 7.8 & .6 \\
\hline milligrams per liter & $.2-$ & 9.0 & 2.9 \\
\hline Specific conductance & $20-41,000$ & 862 & 1,910 \\
\hline Total alkalinity & $-\quad 477$ & 144 & 78 \\
\hline Total hardness & $-2,000$ & 248 & 228 \\
\hline - do & $.01-$ & 1.52 & 1.59 \\
\hline Total phosphorus & $.0-$ & .2 & .3 \\
\hline
\end{tabular}

\section{SPECIES INFORMATION}

Refer to Pascher (1913) and Prescott (1962). 


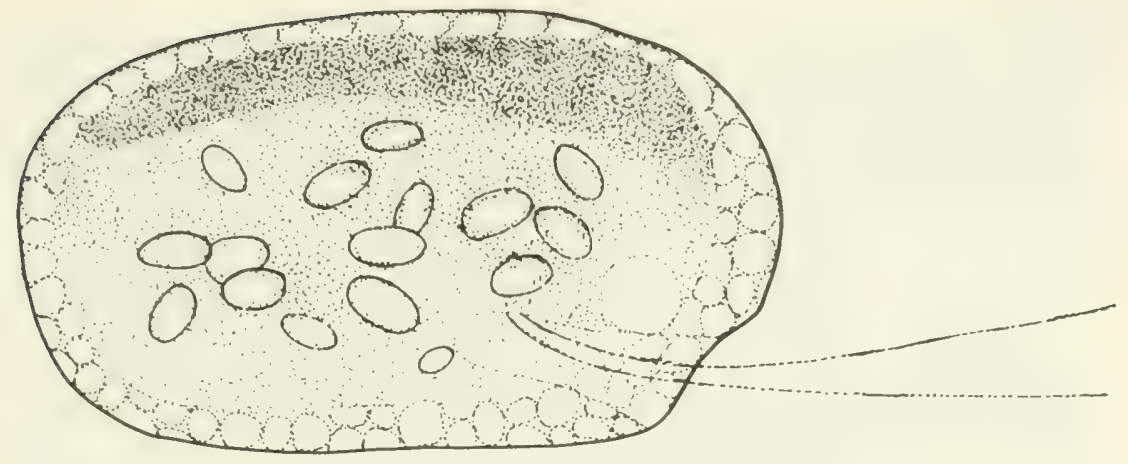

Figure 48.-Drawing of Cryptomonas. 
Division Cyanophyta Class Cyanophyceae

Order Chyroococcales

Family Chroococcaceae

GENUS AGMENELLUM Drouet and Daily, 1956 (fig. 49)

Generic Synonym.-Merismopedia Meyen, 1839

\section{MORPHOLOGY}

Cells are spherical or almost hemispherical when dividing. They are contained in free-floating, multicelled colonies. Cells, 3-6 $\mu \mathrm{m}$ wide, are regularly arranged in parallel vertical and transverse rows. The colony is 1 cell in thickness. The gelatinous matrix is homogeneous and colorless.

\section{REPRODUCTION}

Reproduction is by cell division and colony fragmentation.

\section{OCCURRENCE}

Agmenellum is widely distributed and generally is indicative of softwater and acidic conditions.

\section{ENVIRONMENTAL CONDITIONS}

\begin{tabular}{|c|c|c|c|}
\hline & Range & Mean & $\begin{array}{l}\text { Standard } \\
\text { deviation }\end{array}$ \\
\hline 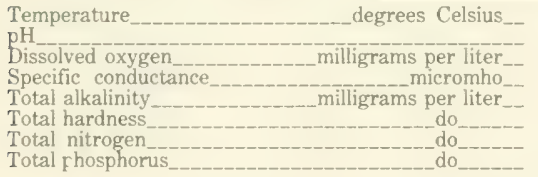 & $\begin{array}{rr}0.0- & 36.0 \\
5.6- & 9.4 \\
.1- & 20.6 \\
26 & -39,500 \\
1 & -450 \\
4 & -2,000 \\
.01- & 21.0 \\
.0 & -\quad 3.1\end{array}$ & $\begin{array}{r}22.5 \\
7.7 \\
8.2 \\
1,190 \\
120 \\
241 \\
1.52 \\
.2\end{array}$ & $\begin{array}{r}7.2 \\
.6 \\
2.4 \\
2,720 \\
78 \\
272 \\
1.63 \\
.3\end{array}$ \\
\hline
\end{tabular}

SPECIES INFORMATION

Refer to Thompson (1938), Geitler (1930), and Prescott (1962). 


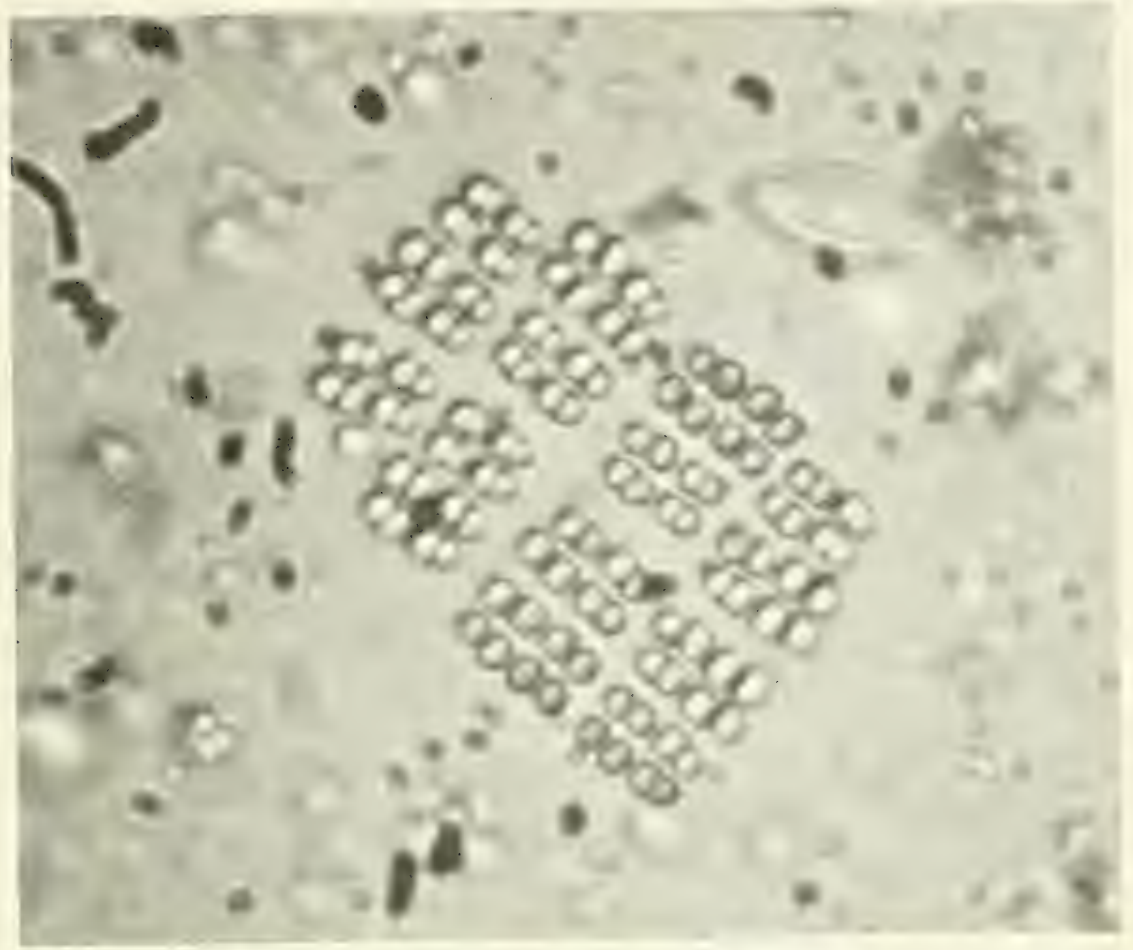

Figure 49.-Photomicrograph of Agmenellum. 
Division Cyanophyta

Class Cyanophyceae

Order Hormogonales

Family Nostocaceae

GENUS ANABAENA Bory, 1822 (fig. 50)

\section{MORPHOLOGY}

Cells are spherical to barrel shaped, are homogeneous or granulose, and sometimes contain pseudovacuoles. They are united into freefloating, beadlike trichomes that are solitary or aggregated. Trichomes are cylindrical or slightly attentuated at the apices. They may be straight, circinate, or spirally or irregularly twisted. Intercalary heterocysts are spherical. Akinetes are variously shaped.

\section{REPRODUCTION}

Reproduction is by heterocysts and akinetes.

\section{OCCURRENCE}

The genus is found commonly in the euplankton and tychoplankton of hard water or eutrophic water during periods of high temperature. It is a frequent component of algal blooms and is indicative of hard water having a high nutrient content when occurring with Aphanizomenon or Anacystis.

ENVIRONMENTAL CONDITIONS

\begin{tabular}{|c|c|c|c|}
\hline & Range & Mean & $\begin{array}{l}\text { Standard } \\
\text { deviation }\end{array}$ \\
\hline ____degrees Celsius___ & $0.0-$ & 20.1 & 7.7 \\
\hline $\mathrm{pH}$ & $4.4-$ & 7.6 & .7 \\
\hline Dissolved oxygen & $.4-19.0$ & 8.3 & 2.3 \\
\hline Specific conductance & $12^{-30,000}$ & $:: 7$ & 1,650 \\
\hline Total alkalinity & $0-371$ & 102 & 73 \\
\hline Total hardness & $5-1,600$ & 173 & 195 \\
\hline Total nitrogen & $.00-\quad 18.0$ & 1.34 & 1.64 \\
\hline Total phosphorus & $.0-$ & .2 & .4 \\
\hline
\end{tabular}

\section{SPECIES INFORMATION}

Refer to Geitler (1932) and Prescott (1962). 


\section{委}

\section{4.}

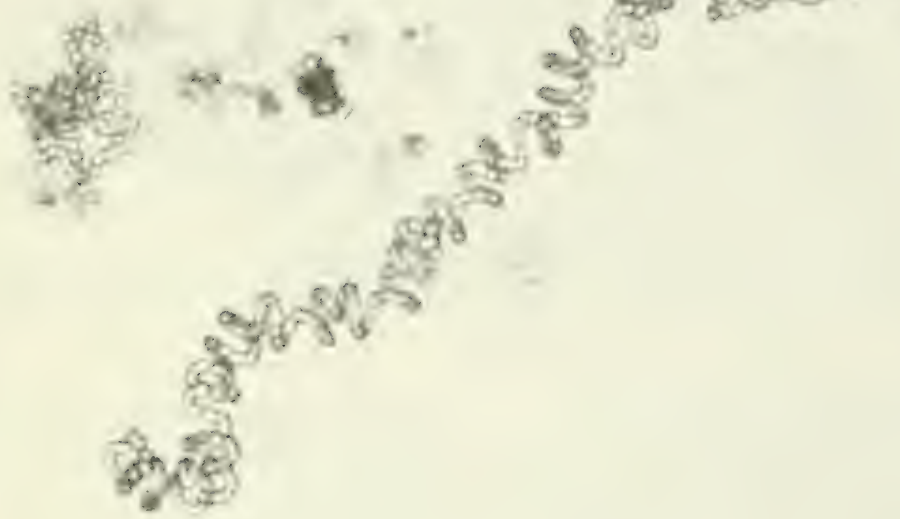

Figure 50.-Photomicrograph of Anabaena. 


\section{Division Cyanophyta}

Class Cyanophyceae

Order Chroococcales

Family Chroococcaceae

GENUS ANACYSTIS Meneghini, 1837; emend., Daily, 1942 (fig. 51)

Generic Synonyms. - Microcystis Kützing, 1833; Polycystis Kützing, 1849; Clathrocystis Henfrey, 1956.

\section{MORPHOLOGY}

Cells are spherical or almost hemispherical when dividing and range from 2 to $10 \mu \mathrm{m}$ in diameter. They are irregularly and densely aggregated in a free-floating, colonial, gelatinous matrix. Colonies are amorphous.

\section{REPRODUCTION}

Reproduction is by cell division and colony fragmentation.

\section{OCCURRENCE}

Anacystis is very common in hard water or eutrophic water during periods of high temperature. It is a frequent component of algal blooms and is notorious as a spoiler of water for domestic uses, swimming, and other forms of recreation. The alga often causes death of fish in heavily infested lakes. It is indicative of hard water with high nutrient content when occurring in large numbers with Aphanizomenon or Anabaena.

\section{ENVIRONMENTAL CONDITIONS}

\begin{tabular}{|c|c|c|c|}
\hline & Range & Mean & $\begin{array}{l}\text { Standard } \\
\text { deviation }\end{array}$ \\
\hline __-__-_-_____degrees Celsius__ & $0.0-$ & 19.1 & 8.1 \\
\hline $\mathrm{pH}_{-}$ & $3.7-$ & 7.6 & .7 \\
\hline Dissolved oxygen & $.1-$ & 8.5 & 2.4 \\
\hline Specific conductance & $10^{\circ}-48,000$ & 866 & $2,180^{2.8}$ \\
\hline Total alkalinity ___ milligrams per liter & $-\quad 500$ & 113 & 81 \\
\hline Total hardness & $-2,000$ & 207 & 246 \\
\hline Total nitrogen & $.00-\quad 41.0$ & 1.46 & 1.70 \\
\hline Total phosphorus & 0 - & 2 & .3 \\
\hline
\end{tabular}

\section{SPECIES INFORMATION}

Refer to Daily (1942), Elenkin (1924), Drouet and Daily (1939), Teiling (1946), and Prescott (1962). 


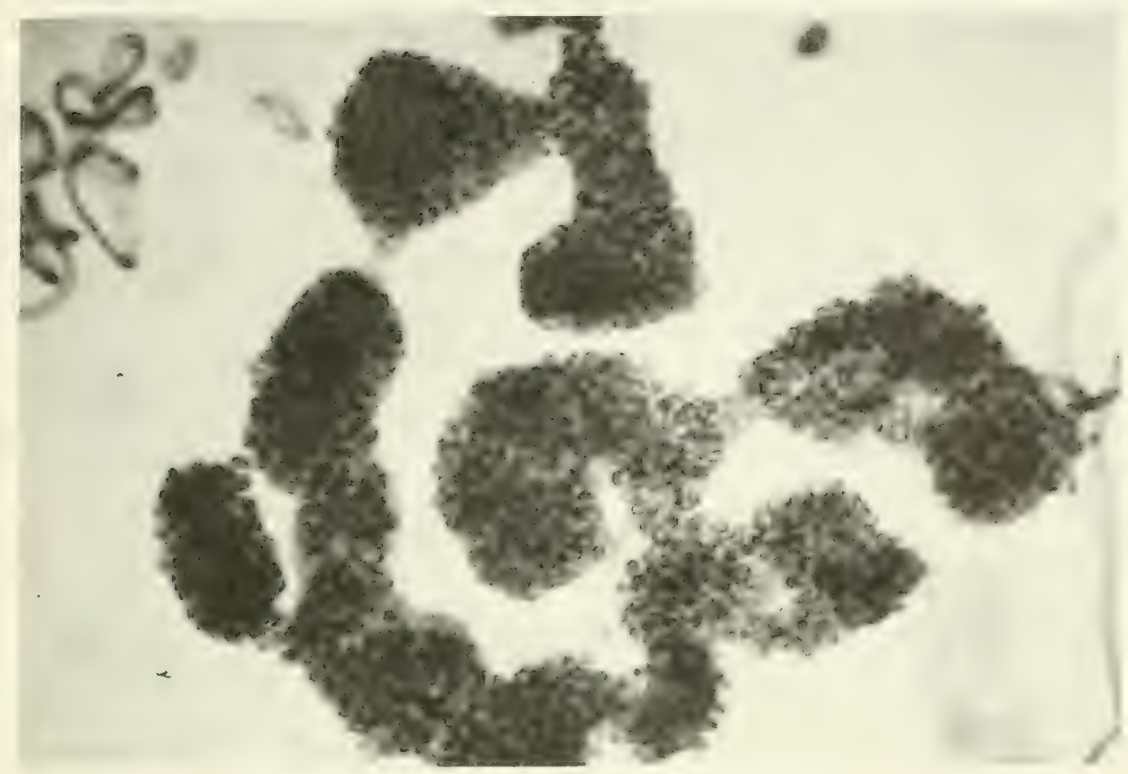

FIGURE 51. - Photomicrograph of Anacystis. 
Division Cyanophyta

Class Cyanophyceae

Order Hormogonales

Family Nostocaceae

GENUS APHANIZOMENON Morren, 1838 (fig. 52)

\section{MORPHOLOGY}

Cells are cylindrical or barrel shaped and rarely exceed $5 \mu \mathrm{m}$ in diameter. They are united into straight or slightly curved trichomes, which are laterally agglutinated by indistinct sheaths. Trichomes are free floating. Intercalary heterocysts are cylindrical. Akinetes are cylindrical.

\section{REPRODUCTION}

Reproduction is by heterocysts and akinetes.

\section{OCGURRENCE}

The single species, Aphanizomenon flos-aquae, is so consistently related to hard water that it may be used as an index organism for high $\mathrm{pH}$ and high contents of nitrogen, phosphorus, and carbonate. It is a notorious component of algal blooms and occurs commonly with Anabaena and Anacystis.

\section{ENVIRONMENTAL CONDITIONS}

\begin{tabular}{|c|c|c|c|}
\hline & Range & Mean & $\begin{array}{l}\text { Standard } \\
\text { deviation }\end{array}$ \\
\hline _______degrees Celsius___ & $0.0-$ & 19.2 & 8.3 \\
\hline 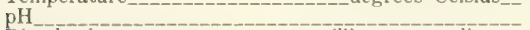 & $4.6-$ & 7.7 & .6 \\
\hline Dissolved oxygen & $2.0-$ & 8.4 & 2.3 \\
\hline Specific conductance & $11-42,000$ & 877 & 2,870 \\
\hline Total alkalinity & $-\quad 311$ & 109 & 68 \\
\hline Total hardness & $6-1,700$ & 193 & 203 \\
\hline Total nitrogen & $.05-\quad 24.0$ & 1.61 & 2.12 \\
\hline Total phosphorus & $.0-$ & .2 & .3 \\
\hline
\end{tabular}

SPECIES INFORMATION

Refer to Smith (1920) and Prescott (1962). 
FIGURE 52.-Photomicrograph of Aphanizomenon. 
Division Cyanophyta

Class Cyanophyceae

Order Hormongonales

Family Nostocaceae

GENUS CYLINDROSPERMUM Kützing, 1843 (fig. 53)

\section{MORPHOLOGY}

Cells are cylindrical and united into short, straight trichomes. Cells range from 2 to $5 \mu \mathrm{m}$ in diameter. Trichomes are free floating or found on moist soil. Heterocysts are cylindrical and always terminal. Akinetes are contiguous to heterocysts.

\section{REPRODUCTION}

Reproduction is by heterocysts and akinetes.

\section{OCCURRENCE}

The genus commonly occurs in the tychoplankton and periphyton. The more common species occur in hard-water, alkaline conditions.

ENVIRONMENTAL CONDITIONS

\begin{tabular}{|c|c|c|c|}
\hline & Range & Mean & $\begin{array}{l}\text { Standard } \\
\text { deviation }\end{array}$ \\
\hline degrees Celsius _._ & $1.5-$ & 24.2 & 6.3 \\
\hline $\mathrm{pH}$ & $5.9-$ & 7.6 & .7 \\
\hline Dissolved oxygen & $1.7-$ & 7.6 & 2.3 \\
\hline Specific conductance micromho & $35-12,000$ & 999 & 1,470 \\
\hline Total alkalinity_____________milligrams per liter & $-\quad 430$ & 107 & 73 \\
\hline Total hardness & $-1,600$ & 235 & 239 \\
\hline Total nitrogen & $.10-\quad 18.0$ & 1.39 & 1.80 \\
\hline Total phosphorus & $.0-$ & .2 & .3 \\
\hline
\end{tabular}

\section{SPECIES INFORMATION}

Refer to Geitler (1932) and Prescott (1962). 


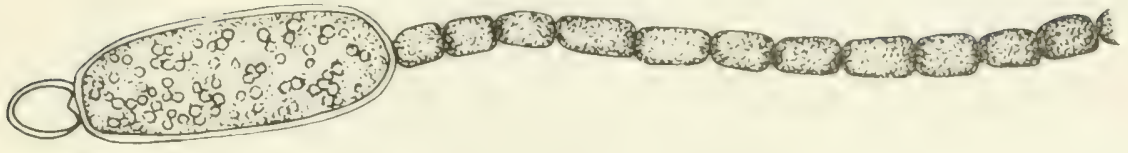

FIGURE 53.-Drawing of Cylindrospermum. 
Division Cyanophyta

Class Cyanophyceae Order Chroococcales

Family Chroococcaceae

GENUS GOMPHOSPHAERIA Kützing, 1836 (fig. 54)

\section{MORPHOLOGY}

Cells are pyriform, obovoid, or cylindrical; when dividing, they are heart shaped or obcuniform. Cells are peripherally distributed in a single layer with long axes radiating in a globous colony. Each cell has a distinct individual sheath, and each has a gelatinous projection at its base. Projections from all cells are joined toward the center of the colony. The colonial matrix is gelatinous.

\section{REPRODUCTION}

Reproduction is by cell division and colony fragmentation.

\section{OCCURRENCE}

The genus is of widespread distribution in the euplankton and tychoplankton of both soitt-water and hard-water bodies.

ENVIRONMENTAL CONDITIONS

\begin{tabular}{|c|c|c|c|}
\hline & Range & Mean & $\begin{array}{l}\text { Standard } \\
\text { deviation }\end{array}$ \\
\hline _._._degrees Celsius__ & $0.0-33.5$ & 19.6 & 8.2 \\
\hline $\mathrm{pH}$ & $4.9-$ & 7.7 & .6 \\
\hline milligrams per liter & 18.4 & 8.6 & 2.5 \\
\hline Specific conductance ____ micromho__ & $32-9,230$ & 556 & 796 \\
\hline Total alkalinity & -426 & 111 & 73 \\
\hline Total hardness & $-1,400$ & 173 & 158 \\
\hline - & $.01-\quad 6.7$ & 1.24 & .99 \\
\hline Total phosphorus & $.0-$ & .1 & .2 \\
\hline
\end{tabular}

SPECIES INFORMATION

Refer to Smith (1920) and Prescott (1962). 


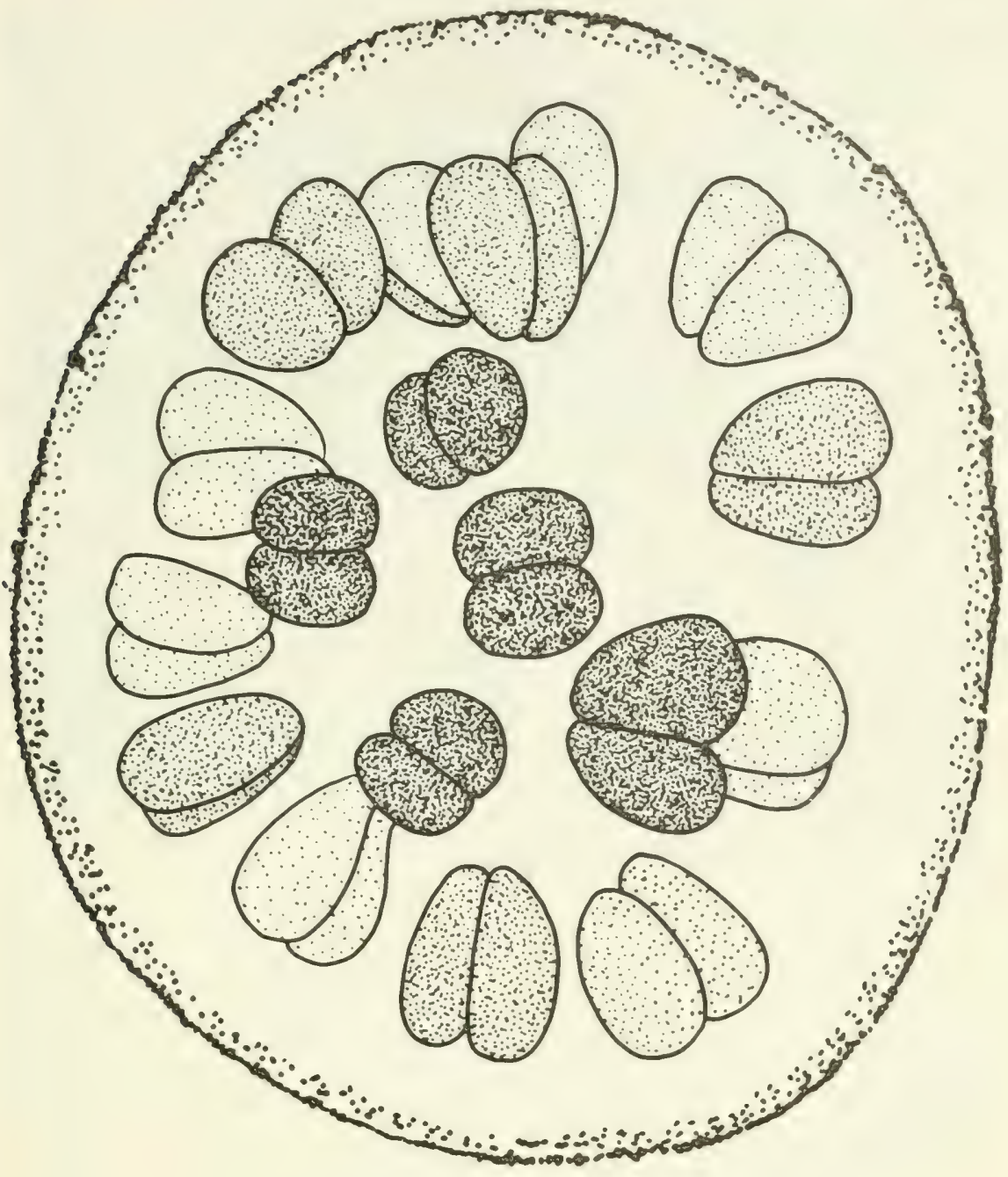

Figure 54.-Drawing of Gomphosphaeria. 


\section{Division Cyanophyta \\ Class Cyanophyceae \\ Order Hormogonales \\ Family Oscillatoriaceae}

GENUS LYNGBYA Agardh, 1824 (fig. 55)

\section{MORPHOLOGY}

Cells are discoidal and adjoined at the flat faces into long trichomes. Trichomes are unbranched, uniseriate, the same diameter from base to apex, and contained in firm, conspicuous sheaths. Filaments are straight, curved, or twisted and may be solitary or densely intertwined into floccose masses. They may be free floating or epiphytic. Heterocysts and akinetes are lacking.

\section{REPRODUCTION}

Reproduction is by hormogonia.

\section{OCCURENCE}

The genus is found commonly in eutrophic waters, and it is generally indicative of hard water. It can occur in great numbers in eutrophic lakes, where it remains distributed through the water column. It is found in both the euplankton and tychoplankton.

ENVIRONMENTAL CONDITIONS

\begin{tabular}{|c|c|c|c|}
\hline & Range & Mean & $\begin{array}{l}\text { Standard } \\
\text { deviation }\end{array}$ \\
\hline 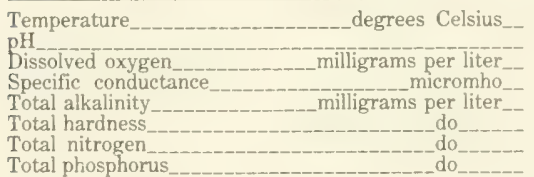 & $\begin{array}{rr}0.0 & -\quad 34.5 \\
4.1- & 9.2 \\
.1- & 20.6 \\
24 & -48,000 \\
0 & -478 \\
3 & -2,000 \\
.01- & 18.0 \\
.0 & 4.0\end{array}$ & $\begin{array}{l}16.7 \\
7.5 \\
8.7 \\
952 \\
113 \\
216 \\
1.58 \\
2\end{array}$ & $\begin{array}{r}9.9 \\
.7 \\
2.8 \\
2,440 \\
83 \\
256 \\
1.82 \\
.4\end{array}$ \\
\hline
\end{tabular}

\section{SPECIES INFORMATION}

Refer to Gomont (1892a), Geitler (1932), and Prescott (1962). 


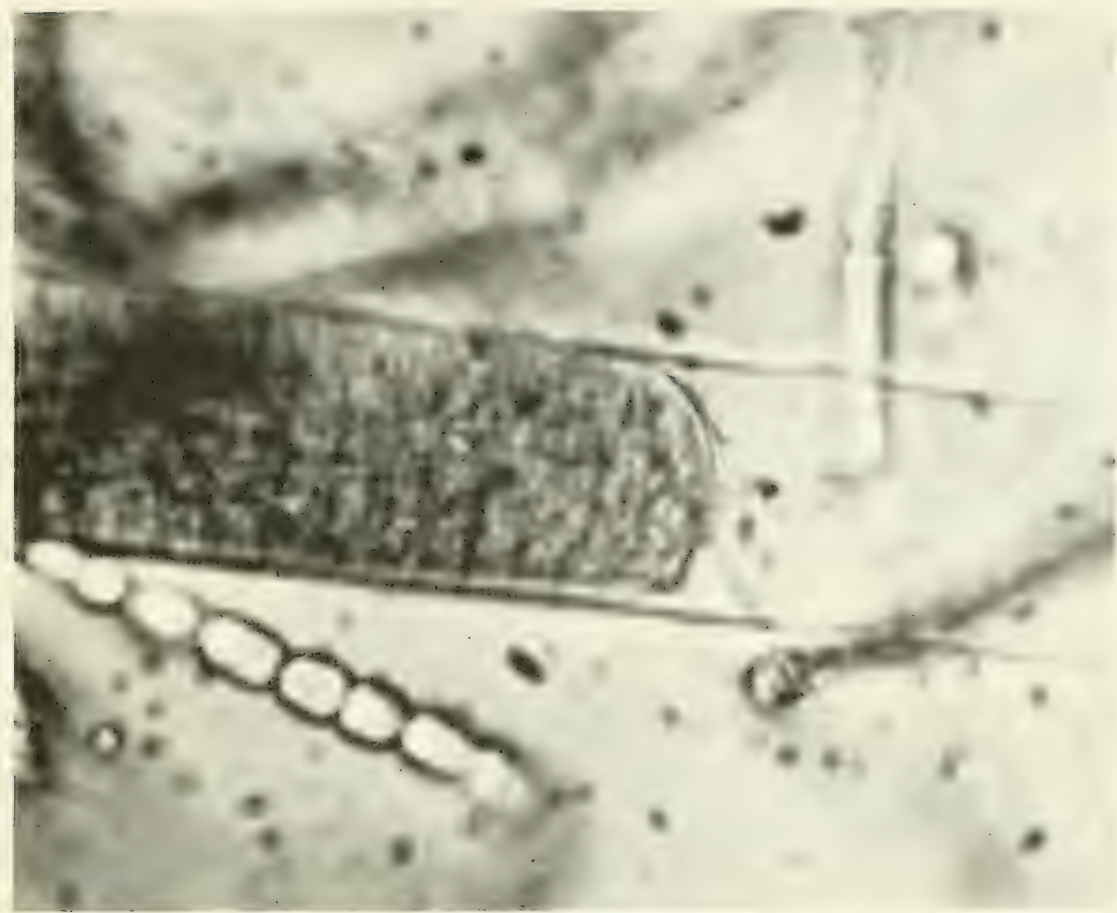

FIGURE 55. - Photomicrograph of Lyngbya. 


\section{Division Cyanophyta}

Class Cyanophyceae

Order Hormogonales

Family Oscillatoriaceae

GENUS OSCILLATORIA Vaucher, 1803 (fig. 56)

\section{MORPHOLOGY}

Cells are discoidal and adjoined at the flat surfaces into long trichomes. Trichomes are unbranched, uniseriate, and sometimes apically attenuated. Sheaths are not evident. Filaments are straight, curved, or contorted and may be solitary or in floccose masses. They are free floating or epiphytic. Heterocysts and akinetes are lacking.

\section{REPRODUCTION}

Reproduction is by hormogonia.

\section{OCCURRENCE}

Oscillatoria is one of the most ubiquitous of the algal genera. It is widely distributed in all types of waters and is found commonly in the euplankton, tychoplankton, and periphyton.

\section{ENVIRONMENTAL CONDITIONS}

\begin{tabular}{|c|c|c|c|}
\hline & Range & Mean & $\begin{array}{l}\text { Standard } \\
\text { deviation }\end{array}$ \\
\hline ______________egrees Celsius___ & $0.0-$ & 16.9 & 9.3 \\
\hline $\mathrm{pH}$ & $3.4-$ & 7.6 & .7 \\
\hline Dissolved oxygen ____________milligrams per liter & $.1-$ & 8.8 & 2.7 \\
\hline Specific conductance & $10-48,000$ & 923 & 2,210 \\
\hline Total alkalinity & $-\quad 500$ & 119 & 81 \\
\hline Total hardness___._. do & $-2,000$ & 223 & 257 \\
\hline Total nitrogen & $.00-\quad 28.0$ & 1.68 & 2.07 \\
\hline Total phosphorus & $.0-$ & .2 & .4 \\
\hline
\end{tabular}

\section{SPECIES INFORMATION}

Refer to Gomont (1892a, b) and Prescott (1962). 


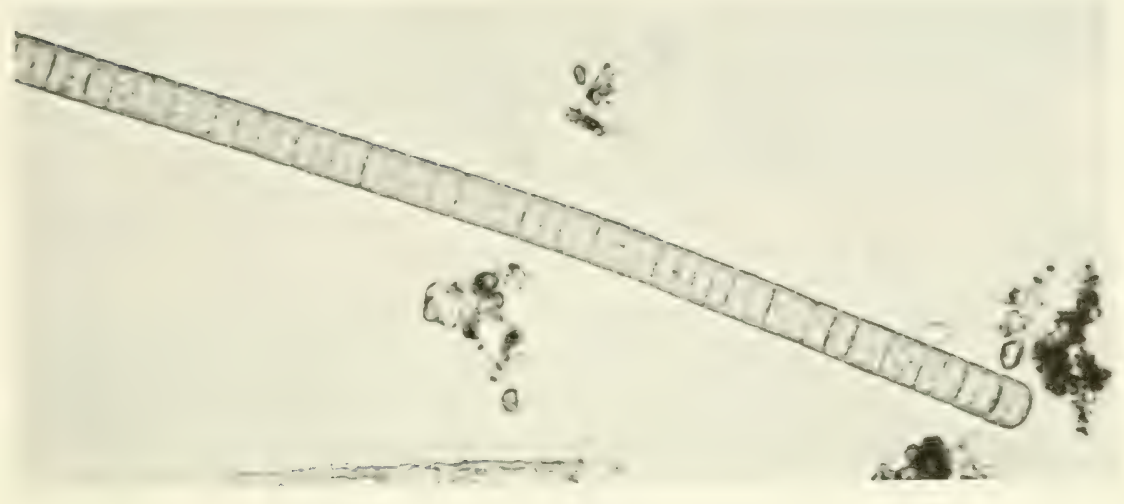

FIGURE 56. - Photomicrograph of Oscillatoria. 
Division Cyanophyta

Class Cyanophyceae

Order Hormogonales

Family Oscillatoriaceae

GENUS PHORMIDIUM Kützing, 1843 (fig. 57)

\section{MORPHOLOGY}

Cells are discoidal and adjoined at the flat surfaces into trichomes. Trichomes are unbranched, cylindrical, and enclosed by watery gelatinous sheaths, which are partially or wholly confluent. Apices are varied, sometimes capitate, often having calyptra. The plant mass is aquatic or subaerial; it often forms an extensive stratum.

\section{REPRODUCTION}

Reproduction is by hormogonia.

\section{OCCURRENCE}

The genus is found primarily on moist rocks or damp soil (Smith, 1950); however, it is commonly found in the euplankton, tychoplankton, and periphyton. It occurs most commonly in hard water.

\section{ENVIRONMENTAL CONDITIONS}

\begin{tabular}{|c|c|c|c|}
\hline & Range & Mean & $\begin{array}{l}\text { Standard } \\
\text { deviation }\end{array}$ \\
\hline _______degrees Celsius___ & $0.0-$ & 20.4 & 8.5 \\
\hline $\mathrm{pH}$ & $4.8-$ & 7.6 & .6 \\
\hline Dissolved oxygen & $1.2-$ & 7.7 & 2.5 \\
\hline Specific conductance & $30-48,000$ & 999 & 4,080 \\
\hline Total alkalinity & $-\quad 363$ & 114 & 75 \\
\hline Total hardness & $7-1,200$ & 204 & 216 \\
\hline Total nitrogen & $.02-$ & 1.50 & 1.93 \\
\hline Total phosphorus & $.0-$ & .2 & .4 \\
\hline
\end{tabular}

\section{SPECIES INFORMATION}

Refer to Gomont (1892a, b), Geitler (1932), and Prescott (1962). 


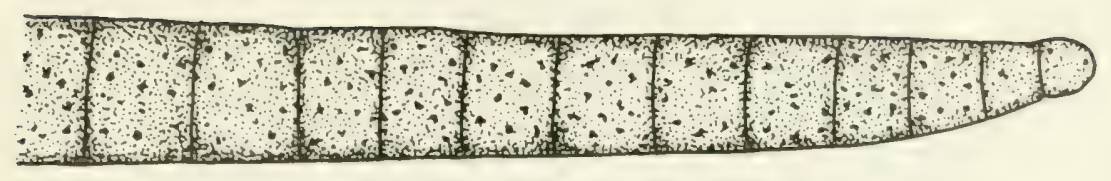

Figure 57.-Drawing of Phormidium. 


\section{Division Cyanophyta}

Class Cyanophyceae

Order Hormogonales

Family Rivulariaceae

GENUS RAPHIDIOPSIS Fritsch and Rich, 1929 (fig. 58)

\section{MORPHOLOGY}

Cells are cylindrical and about $4.5 \mu \mathrm{m}$ in diameter. They are 1.5-2 times as long as wide. The solitary, free-floating trichomes are relatively short. The sheath is absent. Both poles of a trichome may be tapered, or one pole may be tapered and the other, broadly rounded. Numerous pseudovacuoles may be present. Akinetes are barrel shaped and are located in the middle of the trichome.

\section{REPRODUCTION}

The trichome breaks transversely into equal halves. Akinetes may be found midway in the trichome.

\section{OCCURRENCE}

The trichomes of the genus are free floating.

ENVIRONMENTAL CONDITIONS

\begin{tabular}{|c|c|c|c|}
\hline & Range & Mean & $\begin{array}{l}\text { Standard } \\
\text { deviation }\end{array}$ \\
\hline 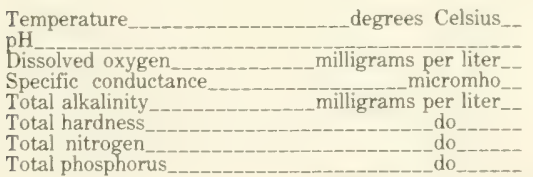 & $\begin{array}{rr}0.0- & 36.0 \\
4.9- & 9.1 \\
.1- & 15.0 \\
20-48,000 \\
1-483 \\
4-1,500 \\
.06-\quad 9.8 \\
.0-\quad 3.5\end{array}$ & $\begin{array}{c}19.7 \\
7.6 \\
8.1 \\
783 \\
105 \\
179 \\
1.43 \\
.2\end{array}$ & $\begin{array}{c}8.7 \\
.7 \\
2.5 \\
2,810 \\
83 \\
200 \\
1.42 \\
.3\end{array}$ \\
\hline
\end{tabular}

\section{SPECIES INFORMATION}

Refer to Fritsch and Rich (1929) and Daily (1945). 


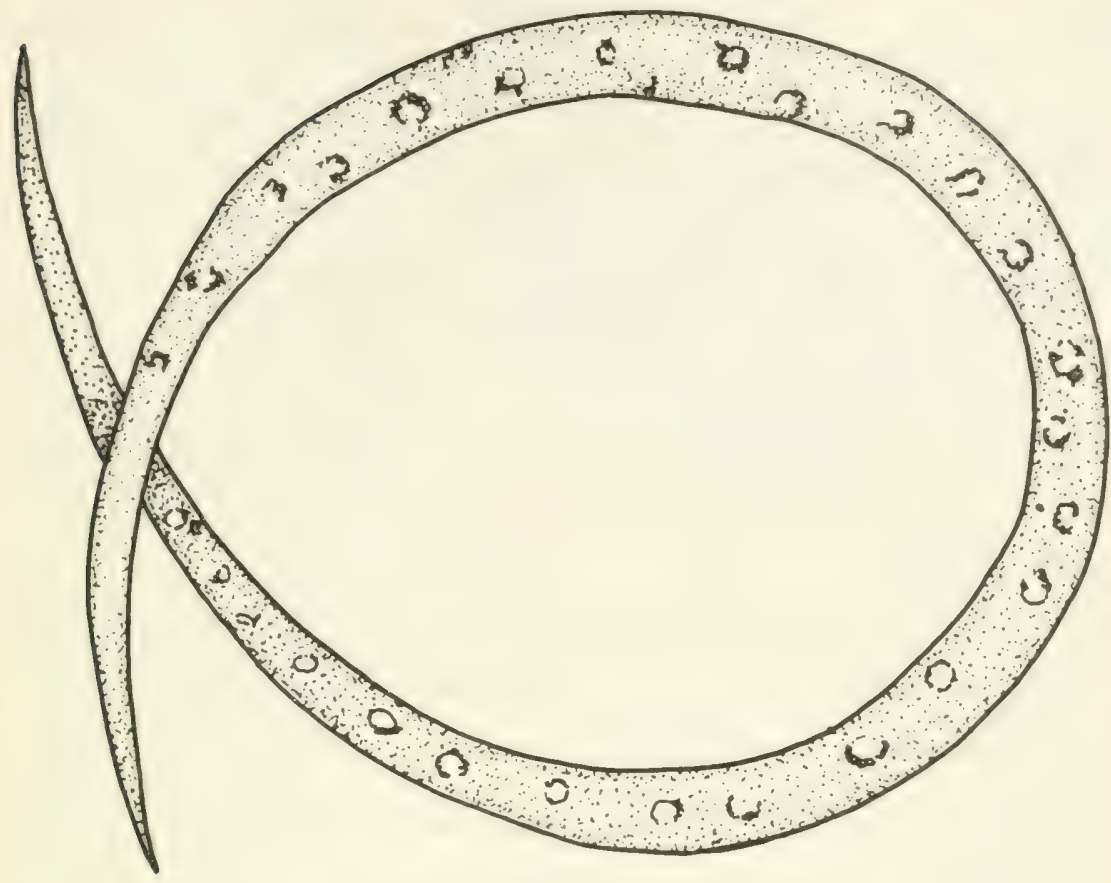

Figure 58.-Drawing of Raphidiopsis. 


\section{GLOSSARY}

[adj, adjective; $n$, noun; v, verb]

Acicular (adj). Slenderly needle shaped.

Adiametric (adj). Having unequal diameters.

Agglutinate (adj). Adherent; sticking together.

Aggregate (adj). Massed together.

Akinete (n). A nonmotile spore, formed directly from a vegetative cell.

Alga, algae (n), algal (adj). A group of plants, mostly aquatic, single celled, colonial, or multicelled, containing chlorophyll and lacking roots, stems, and leaves.

Amorphous (adj). Lacking a definite shape.

Anapex (n), anapical (adj). The bottom or end opposite the apex.

Anisogamy (n), anisogamous (adj). The sexual union of two flagellated or nonflagellated gametes of unequal sizes.

Anterior (adj). At or toward the front.

Antherozoid (n). A male gamete.

Apex (n), apical (adj). The top or anterior end.

Aplanospore (n). A nonmotile spore formed from all or part of the protoplast of a vegetative cell and having a wall distinctly different from that of the parent cell.

Apposed (adj). Paired; opposite but in a definite relation to one another.

Arcuate (adj). Moderately curved like a bow.

Asymmetrical (adj). Not symmetrical.

Attenuated (adj). Tapering at the end.

Autospore (n). An aplanospore having the same shape as the vegetative cell from which it was formed.

Auxospore (n). A spore formed by asexual metamorphosis of the protoplast of one cell or resulting from the sexual fusion of two protoplasts or nuclei; occurs only in diatoms.

Biflagellate (adj). Having two flagella.

Bifurcate (adj). Divided into two parts or branches.

Bipartition (adj). Divided into two parts.

Calyptra (n). A hood- or cap-shaped covering, sometimes occurring on apical cells of filaments.

Campanulate (adj). Bell shaped.

Capitate (adj). Having a knoblike end.

Chloroplast (n). A body in the cell containing chlorophyll as the dominant pigment; see chromatophore.

Chromatophore (n). A body in the cell containing the pigments; see chloroplast.

Circinate (adj). Rolled inward from the apex.

Citriform (adj). Lemon shaped.

Clevate (adj). Club shaped.

Coenobium, coenobia (n). A colony in which a definite number of cells are arranged in a specific way.

Coenocyte (n), coenocytic (adj). A multinucleate vegetative cell or nonseptate thallus.

Colony ( $n$ ), colonial (adj). A group of individuals joined together by a common sheath or gelatinous material; a group of cells forming a filament or trichome.

Concentric (adj). Having a common center.

Conical (adj). Cone shaped.

Conjugation (n), conjugate (v). The union of gametes.

Contractile (adj). Having the ability to contract or expand.

Costa, costae (n), costate (adj). A rib or ribbed structure.

Cuneate (adj). Wedge shaped.

Dichotomous (adj). Divided or branched into two parts; branched.

Diffuse (adj). Generalized; not localized. 
Discoid (adj). Disc shaped.

Epitheca, epithecae (n). The larger or epivalve of a diatom cell; part of the wall of a dinoflagellate, anterior to the transverse furrow.

Euplankton (n). True plankton.

Eyespot (n). A small pigmented photosensitive body in certain flagellated algal cells.

Fascicle (n), fasciculate (adj). A bundle or cluster.

Filament (n), filamentous (adj). A linear arrangement of cells.

Flagellum, flagella (n), flagellate (adj). A fine long threadlike structure having lashing or undulating movement, projecting from a cell; it is used for locomotion.

Frustule (n). A diatom cell; the silicified wall of the diatom cell.

Furcate (adj). Forked.

Fusiform (adj). Spindle shaped.

Gamete (n), gametic (adj). A sex cell.

Gelatinous (adj). Having a jellylike or mucilagelike texture or appearance.

Gibbose (adj). Swollen on one side.

Girdle (n). A ring or band connecting two valves in diatoms; a transverse groove.

Globose (adj). Ball shaped or nearly so.

Granulate, granulose (adj). Composed of or appearing to be covered with granules.

Gullet (n). An anterior opening of flagellates.

Heterocyst (n). A metamorphosed vegetative cell in diatoms; sometimes forms endospores or a filament.

Heterothallus ( $n$ ), heterothallic (adj). A species in which gametes unite only if arising from different plants.

Homothallus (n), homothallic (adj). A species in which gametes unite only if arising within the same plant.

Hormogonium, hormogonia (n). A short, distinct section of a trichome that produces a new plant vegetatively.

Hyaline (adj). Colorless and transparent.

Hypotheca, hypothecae (n). The small or hypovalve of a diatom cell; part of the wall of a dinoflagellate, posterior to the transverse furrow.

Inflated (adj). Swollen.

Intercalary (adj). Between or inserted between cells.

Isodiametric (adj). Having equal diameters.

Isogamy (n), isogamous (adj). Sexual union of two flagellated or nonflagellated gametes of equal size.

Keel (n). A projecting ridge.

Laminate (adj). Consisting of or shaped like plates.

Lanceolate (adj). Lance shaped.

Linear (adj.). Straight; narrow and long.

Lorica (n). A firm covering that is not connected to the protoplast and contains an anterior opening.

Lunate (adj). Crescent shaped.

Macrophyte (n). Large plants that can be seen without magnification; includes mosses and seed plants.

Mucilage (n). A thick, watery substance.

Multiseriate (adj). Occurring in several rows.

Naviculoid (adj). Boat shaped.

Nodule (n). A small knob.

Obcuniform (adj). Inversely wedge shaped.

Obovoid (adj). Inversely ovoid, with the broader end anterior or outermost.

Oogamy (n). oogamous (adj). Sexual union of a small motile male gamete (sperm) with a large nonmotile female gamete (egg). 
Ovate, ovoid (adj). Oval; egg shaped.

Palmella (n), palmelloid (adj). A genus of green algae, whose spherical cells are united by their mucilage coats into indefinite mucilaginous masses.

Parietal (adj). Pertaining to or near the wall.

Periphery (n). The outer boundary or edge.

Periphyton (n), periphytic (adj). The community of micro-organisms that are attached to or live upon submerged surfaces.

Phytoplankton (n), phytoplanktonic (adj). The plant part of the plankton.

Plankton (n), planktonic (adj). The community of suspended or floating organisms that drift passively with water currents.

Polar (adj). Pertaining to the pole or end.

Polyhedral (adj). Having numerous faces or planes.

Postcingular (adj). Referring to position of plates adjacent to the girdle of the hypotheca of certain dinoflagellates.

Precingular (adj). Referring to position of plates adjacent to the girdle in the epitheca of certain dinoflagellates.

Protoplast (n). The living contents of a cell; the nucleus, cytoplasm, and plasma membrane that constitute a living unit.

Pseudoraphe (n). The axial field of the valves of pennate diatoms lacking a longitudinal cleft or raphe.

Pseudovacuole (n). A false vacuole; a pocket of gas or fluid within the protoplast.

Puncta, punctae (n), punctate (adj). A tiny spot, dot, point, or depression.

Pyramidal (adj). Pyramid shaped.

Pyriform (adj). Pear shaped.

Quadrate (adj). Square; arranged in fours.

Quadriflagellate (adj). Having four flagella.

Radial (adj). Radiating from a common center or point; pertaining to the radius.

Raphe (n), rapheal (adj). A longitudinal cleft in the axial field of certain pennate diatoms.

Recurved (adj). Curved; bent down.

Reniform (adj). Kidney shaped.

Reticulate (adj). Like a network.

Rhombic (adj). Resembling a rhomboid.

Rostrate (adj). Having a beak.

Semicell (n). One-half of a vegetative cell of a desmid.

Sessile (adj). Pertaining to an organism that is attached to an object.

Seta, setae (n). A slender, more or less rigid bristle, a short hair.

Sheath (n). A covering, envelope, or tube that is composed of mucilage.

Sigmoid (adj). S-shaped.

Solitary (adj). Single; alone.

Spherical (adj). Sphere shaped; globular.

Spicate (adj). Having spikes or spines.

Spine (n). A stiff, pointed process.

Stalk (n). A supporting structure, generally mucilage, affixed to a substrate.

Statospore (n). An asexually formed spore having thick silicified walls composed of two overlapping halves.

Stauros (n). A thickness and transversely expanded central nodule interrupting the raphe of certain diatoms.

Stellate (adj). Star shaped.

Stria, striae (n), striate (adj). Long delicate markings on the frustules of diatoms.

Subacute (adj). Almost pointed.

Subcylindrical (adj). Almost cylindrical in shape. 
Subelliptical (adj). Almost elliptical in shape.

Subpolar (adj). Near the pole, end, or apex.

Subspherical (adj). Almost spherical in shape.

Sulcus (n). A groove or furrow.

Suture (n). The seam or ridge formed by apposed margins,

Tabular (adj). Table shaped; having a flat surface.

Terminal (adj). At or near the end.

Trichome (n). A uniseriate row of cells in a filament; a filament exclusive of a gelatinous sheath.

Truncate (adj). Terminating abruptly by a nearly straight edge or surface.

Tychoplankton (n). Organisms in the plankton, which were scoured from the hottom.

Undulate (adj). Wavy.

Uniflagellate (adj). Having one flagellum.

Uniseriate (adj). In a single row.

Vacuole (n). An area in the protoplasm containing cell fluid and sometimes granules.

Valve (n). The silicified parts of a diatom cell.

Verrucose (adj). Covered with wartlike elevations.

Vesicule (n). A bladderlike structure.

Zoospore (n). A flagellated, asexually formed spore.

Zygote (n), zygotic (adj). A cell resulting from the union of two gametes or gametic nuclei.

\section{SELECTED REFERENCES}

Agardh, C. A., 1824, Systema algarum: Lund, v. 1, 312 p.

Ahlstrom, E. H., 1937, Studies on variability in the genus Dinubmum (Nastigophora): Transactions of the American Microscopical Society, v. 56, p. 139-159.

Ahlstrom, E. H., and Tiffany, L. H., 1934, The algal genus Tetrastmum: American Journal of Botany, v. 21, p. 499-507.

Bigeard, E., 1933, Les Pediastrum d'Europe. Étude biologique et systématique: Trav. Lab. Bot., Univ. Cathol. Angers, no. 5, p. 1-192.

Bold, H. C., and Wynne, M. J., 1978, Introduction to the algae-Structure and reproduction: Englewood Cliffs, N.J., Prentice-Hall, Inc., 706 p.

Bory (de St. Vincent), J. B., 1822-1831, in Dictionnaire d'histoire naturelle: Paris.

Boyer, C. S., 1927a, Synopsis of the North American Dictonaceae, Part 1: Proceedings of the Academy of Natural Sciences of Philadelphia, v. 78, supplement, p. 1-228.

1927b, Synopsis of the North American Diatomaceae, Part 2: Proceedings of the Academy of Natural Sciences of Philadelphia, v. 78, supplement, p. 229-583.

Brunnthaler, J., 1915, Protococcales, in Pascher, A., Die Süsswasserflora Deutschlands, Österreichs, und der Schweiz, Heft 5, Chlorophyceae 2: Jena, p. 52-205.

Chapman, V. J., 1962, The algae: New York, Macmillan, 472 p.

Chodat, R., 1894, Materiaux pour servir à l'histoire des Protococcoidées: Bull. Herb. Boiss., v. 2, p. 585-616.

-1895, Über die Entwickelung der Eremosphaera viridis de By: Bot. Zeitg., v. 53, p. $137-142$.

-1897, Recherches sur les algues pélagiques de quelques lacs suisses et français: Bull. Herb. Boiss., v. 5, 289-314.

1926, Scenedesmus. Etude de génétique, de systématique expérimentale et d'hydrobiology: Revue d'Hydrologie, v. 3, p. 71-258.

Cleve, P. T., 1894, Synopsis of the naviculoid diatoms: Kungliga Svenska Vetenskapsakademiens Handlingar, v. 26, p. 1-194. 
Cleve, P. T., 1895, Synopsis of the naviculoid diatoms: Kungliga Svenska Vetenskapsakademiens Handlingar, v. 27, no. 2, p. 1-219.

Collins, F. S., 1909, The green algae of North America: Boston, Mass., Tufts College Studies, Scientific Series, no. 2, p. 79-480.

Corda, A. J. C., 1835-1839, Observations sur les animalicules microscopiques qu'on trouve auprès des eau thermales de Carlsbad: Almanach de Carlsbad, 1835-1839.

Crow, W. B., 1925, The reproductive differentiation of colonies in Chlamydomonadales: New Phytology, v. 24, p. 120-123.

Daily, W. A., 1942, The Chroococcaceae of Ohio, Kentucky, and Indiana: American Midland Naturalist, v. 27, p. 636-661.

1945, Additions to the filamentous Myxophyceae of Indiana, Kentucky, and Ohio: Butler University Botanical Series, v. 7, p. 132-139.

Davis, C. C., 1955, The marine and freshwater plankton: Lansing, Mich., Michigan State University Press, $562 \mathrm{p}$.

DeCandolle, A. P., 1805, Flore française: Paris.

Deflandre, G., 1926, Monographie du genre Trachelomonas Ehr: Nemours, 162 p.

Drouet, F., and Daily, W. A., 1939, The planktonic freshwater species of Microcystis:

Field Museum Botanical Series, v. 20, p. 67-83.

1956, Revision of the coccoid Myxophyceae: Butler University Botanical Studies, v. 12, p. $1-218$.

Ducellier, F.. 1915, Note sur un nouveau Coelastrum: Bull. Soc. Bot. Genève, v. 7, p. $72-74$.

Ehrenberg, C. G., 1832a, Beiträge zur Kenntniss der Organisation der Infusorien und ihre geographische Verbreitung besonders in Sibirien: Abhandlungen der könglische Akademie der Wissenschaften, 1830, p. 1-88.

-1832, Über die Entwicklung and Lebensdauer der Infusionsthiere; nebst ferneren Beitaragen zu einer Vergleuchung ihrer organischen Systeme: Abhandlungen der könglische Akademie der Wiissenschaften, 1831, p. 1-154.

_ 1835, Dritter Beitrag zur Erkenntniss grosser Organisation in der Richtung des kleinsten Raumes: Abhandlungen der könglische Akademie der Wissenschaften, 1833, p. 145-336.

1837, Zusätze zur Erkenntniss grosser organischer Ausbildung in den kleinsten thierischen Organismen: Abhandlungen der könglische Akademie der Wissenschaften, 1835 , p. $151-180$

1838, Die Infusionsthierchen als vollkommene Organismen: Leipzig.

Elenkin, A. A., 1924, De spec. duabus gen. Microcystis Kutz. notula: Bull. Jard. Imp. Bot. Pierre le Grand, v. 3, no. 1, p. 12-15.

Ficke, J. F., and Hawkinson, R. O., 1975, The National Stream Quality Accounting Network (NASQAN) - Some question and answers: U.S. Geological Survey Circular 719, $23 \mathrm{p}$.

Fjerdingstad, E., 1950, The microfauna of the river Molleaa, with special reference to the relation of benthal algae to pollution: Folia Limnologiae Scandinavica, no. 5, $123 \mathrm{p}$.

Forbes, S. A., 1913, Biological and chemical conditions of the upper Illinois River: Proceedings of the Fifth Meeting, Illinois Water-Supply Association, Urbana.

Fresenius, G., 1858, Beiträge zur Kenntniss mikroskopischer Organismen: Abhandlung Sench. Nat. Ges., Frankfurt, v. 2, p. 211-242.

Fritsch, F. E., and Rich, F., 1929, Freshwater algae (exclusive of diatoms) from Griqualand West: Transactions of the Royal Society of South Africa, v. 18, p. 1-92.

Geitler, L., 1927, Über die Auxosporen von Meridion circulare und verwandten Diatomeen-Gattungen: Mikrokosmos, v. 21, p. 79-82. 
1929, Uber den Bau der kerne zweier Diatomeen: Archiv Protestenk., v. 68, p. $625-636$.

-1930, Cyanophyceae, in Rabenhorst, L., Kryptogamen-Flora von Deutschland, Österreich, und der Schweiz: v. 14, p. 1-288.

1932, Cyanophyceae, in Rabenhorst, L., Kryptogamen-Flora von Deutschland, Österreich, und der Schweiz: vol. 14, p. 673-1056.

Gemeinhardt, K., 1926, Poren and Streifen in der Zellwand der Diatomeen: Berlin deutsch Botanisch Gesellschaft, v. 44, p. 517-526.

Gerloff, J., 1940, Beiträge zur kenntnis der Variabilitat und Systematik der Gattung Chlamydomonas: Archiv Protistenk., v. 94, p. 311-502.

Gomont, M., 1892a, Monographie des Oscillariées (Nostocacées homocystées), Part 1: Ann. Sci. Nat. Bot. VII, v. 15, p. 263-368.

1892b, Monographie des Oscillariées. (Nostocacées homocystées), Part 2: Ann. Sci. Nat. Bot. VII, v. 16, p. 91-264.

Greeson, P. E., 1970, Numerical taxonomy: The systematic categorization of the North American genera of freshwater algae: American Water Resources Association, Proceedings of a Symposium on Hydrobiology, p. 150-161.

ed., 1979, A supplement to methods for collection and analysis of aquatic biological and microbiological samples (U.S. Geological Survey Techniques of Water-Resources Investigations, book 5, chapter A4): U.S. Geological Survey Open-File Report 79-1279, $92 \mathrm{p}$.

Greeson, P. E., Ehlke, T. A., Irwin, G. A., Lium, B. W., and Slack, K.V., eds., 1977, Methods for collection and analysis of aquatic biological and microbiological samples: U.S. Geological Survey Techniques of Water-Resources Investigations, book 5, chap. A4, 332p.

Grunow, A., 1860, Die Desmidiaceen und Pediastreen einiger Österreichischen Moore, nebst einigen Bemerkungen über beilde Familien im Allgemeinen: Ver. K. K. Zool.-Bot. Ges. Wein, v. 8, p. 489-502.

Hansgrirg, A., 1892, Prodromus der Algenflora von Böhmen. Zweiter Theil welcher die blaugrüen Algen (Myxophyceen, Cyanophyceen), nebst Nachträgen zum ersten Theile und einer systematischen Bearbeitung der in Böhmen verbreiteten saprophytischen Bacterien and Engleenen enthält: Archiv für Natural Landes von Böhm, v. 8, p. 1-268.

Harper, R. A., 1961, On the nature of types in Pediastmum: Memoirs of the New York Botanical Garden, v. 6, p. 91-104

1918, Organization, reproduction, and inheritance in Pediastrum: Proceedings of the American Philosophical Society, no. 57, p. 375-439.

Hassall, A. H., 1845, A history of freshwater algae: London, $462 \mathrm{p}$.

1850 , A history of the freshwater algae, including descriptions of Desmidiaceae and Diatomaceae: London, 2 volumes, $462 \mathrm{p}$.

Johnson, L. P., 1944, Euglenae of Iowa: Transactions of the American Miocroscopical Society, v. 63, kp. 97-135.

Kolkwitz, R., and Marrson, M., 1908, Ökologie der pflanzlichen Saprobien: Berichte der Deutschen Botanischen Gesellschaft, v. 262, p. 505-519.

Kützing, F. T., 1833, Algologische Mittheilungen. I. Über Gloionema, Agh. II. Uber eine neue Gattung der Confervaceen: Flora, v. 16, p. 513-528.

1843, Phycologia generalis, oder Anatomie, Physiologie, und Systemkunde der Tange: Leipzig, 458 p.

-1845, Phycologia germanica, d. i. Deutschlands Algen in bündigen Beschreibungen: Nordhausen, $340 \mathrm{p}$.

1849, Species algarum: Leipzig, $922 \mathrm{p}$.

Lackey, J. B., 1939, Notes on plankton flagellates from the Scioto River: Lloydia, v. 2, p. 128-143. 
Lagerheim, G., 1882, Bidrag till kannendomen om Stockholmstrakens Pediastreer, Protococcaceer och Palmellaceer: Öfvers, Kgl. Svensk.-Ak. Forh, v. 39, no. 2, p. 47-81.

Lefèvre, M., 1932, Monographie des espèces d'eau douce de genre Peridinium: Archives de Bot., v. 2, p. 1-210.

Lemmermann, E., 1898, Beiträge zur Kenntnis der Planktonalgen. I. Golenkinia Chodat, Richteriella Lemm., Franceia nov. gen., Phythelios Frenzel. Lagerheimia Chodat, Chodatella nov. gen., Schroederia nov. gen.: Hedwigia, v. 37, p. 303-312.

1899, Das Genus Ophiocytium Naegeli: Hedwigia, v. 38, p. 20-38.

Lyngbye, H. C., 1819, Tentamen Hydrophytologiae Danicae: Kjobenhaun.

Meister, F., 1912, Die Kieselalgen der Schweiz: Beitr. Kryptogamenfl. Schweiz., v. 4, p. $1-254$.

Meneghini, G., 1837, Conspectus algologiae euganeae: Patavia, 37 p.

Meyen, F. J., 1829, Beobachtungen über einige niedere Algenformen: Nova Acta Acad. Caes. Leop.-Carol., v. 14, p. 768-778.

1839, Jahresberichte über die Resultate der Arabeiten im felde der physiologischen Botanik von dem Jahre 1838: Arch. für Naturg., v. 2, p. 1-153.

Morren, Charles, 1830, Mémoire sur un végétal microscopique d'un nouveau genre, proposé sous le nomme Microsoter, ou conservateur des petites choses: Annals of Science in Naturale Botonicae, v. 20, p. 404-426.

-1838, Récherches physiologiques sur les hydrophytes de la Belgique. Prémier Memoire. Histoire d'un genre nouveau de la tribu Confervées, nommé par l'auteur, Aphanizoméne: Memoire Akadamie Royale Belguque, v. 11, p. 5-20.

Nägeli, C. W., 1849, Gattungen einzelligen Algen, physiologische und systematische bearbeitet: Zurich, $137 \mathrm{p}$.

-1855, in Braun, Algarum unicellularum genera nova vel minus cognita: Leipzig, $111 \mathrm{p}$.

Office of Water Research and Technology, 1976, Algal abstracts - A guide to the literature, Volume 3: 1972-1974: New York, IFI/Plenum Data Company, 890 p.

Office of Water Resources Research, 1973a, Algal abstracts - A guide to the literature, Volume 1: to 1969: New York, IFI/Plenum Data Corporation, 585 p.

1973b, Algal abstracts-A guide to the literature, Volume 2: 1970-1972: New York, IFI/Plenum Data Corporation, 693 p.

Pascher, A., 1913, Zur Gliederung der Heterokonten: Hedwigia, v. 53, p. 6-22. 1927, Volvacales-Phytomonadinae, in Pascher, A., Die Süsswasserflora Deutschlands, Österreichs, und der Schweiz, Heft 4: Jena, p. 1-506.

1943, Zur Kenntnis verschiedener Ausbildungen der planktonischen Dinobryon: Inter. Rev. Gesamt. Hydrobiol. Hydrograph, v. 43, p. 110-123.

Patrick, Ruth, 1948, Factors affecting the distribution of diatoms: Botanical Review, v. 14 , p. 473-524.

1949, A proposed biological measure of stream conditions, based on a survey of the Conestoga Basin, Lancaster County, Pennsylvania: Proceedings of Academy of Natural Sciences of Philadelphia, v. 101, p. 277-347.

-1973, Use of algae, especially diatoms, in the assessment of water quality: Philadelphia, American Society for Testing and Materials, ASTM STP 528, p. 76-95.

Patrick, Ruth, and Reimer, C. W., 1966, The diatoms of the United States exclusive of Alaska and Hawaii, Volume 1: Fragilariaceae, Eunotiaceae, Achnanthaceae, Naviculaceae: Philadelphia, Monographs of the Academy of Natural Sciences of Philadelphia, number 13, $688 \mathrm{p}$.

Prescott, G. W. 1962, Algae of the western Great Lakes area with an illustrated key to the genera of desmids and freshwater diatoms: Dubuque, Iowa, William C. Brown Co., $977 \mathrm{p}$.

1968, The algae: A review: Boston, Houghton Mifflin Co., 436 p. 
Printz, H., 1913, Eine systematische Ubersicht der gattung Oöcystis Nägeli: Nyt. Mag. Naturvidensk, v. 51, p. 165-203.

Purdy, W. C. 1922, A study of the pollution and natural purification of the Ohio River, I. The plankton and related organisms: U.S. Public Health Service Bulletin no. 131, p. $1-78$.

Rabenhorst, L.. 1864, Florae Europaea algarum aguae delcis et submariane: Leipzig, 3 volumes.

Ralfs, J., 1848, The British Desmidieae: London, $226 \mathrm{p}$.

Reinsch, P. F., 1867, Die Algenflora des mittleren Theils von Franken: Nüremberg, 238 p.

-1888, Familiae Polyedriearum monographia: Notarisia, v. 3, p. 493-516.

Rosenberg, M., 1944, On a blue-green cryptomonad, Chroomonas Nordstedtii Hansg.: Annals of Botany, v. 8, p. 315-322.

Rosowski, J. R., and Parker, B. C., eds., 1971, Selected papers in phycology: Lincoln, University of Nebraska, $876 \mathrm{p}$.

Schiller, J., 1933, Dinoflagellatae (Peridineae) und Verwandte, in Raberhorst, Kryptogamen-Flora Deutschlands, Österreich, und der Schweiz: v. 10, Abt. 3, 1 Teil, p. 1-617.

Schmidle, W., 1893, Beiträge zur Algenflora des Schwarzwaldes und der Rheinbene: Ber. d. Natur. Ges. Freiburg, v. 7, p. 1-45.

Schmidt, P., 1923, Morphologie und Biologie der Melosira varians mit einem Beitrag zur Mikrosporenfrage: Internat. Rev. Gesamt. Hydrobiol. Hydrograph, v. 11, p. 114-147.

Schütt, F., 1896, Bacillariales. in Engler and Prantl, Die naturlichen Pfanzenfamilien: v. 1 p. $31-150$.

Skvortzow, B. B., 1925, Die Euglenaceengattung Trachelomonas Ehrenberg. Eine systematische Übersicht: Proceedings of the Sungari River Biological Station, no. 1, p. $1-101$.

1937, Diatoms from Lake Michigan. I: American Midland Naturalist, v. 18, p. $652-658$.

Smith, G. M., 1916, A monograph of the algal genus Scenedesmus based upon pure culture studies: Transactions of the Wisconsin Academy, v. 18, p. 422-530.

-1920 , Phytoplankton of the inland lakes of Wisconsin: Bulletin of the Wisconsin Geological and Natural History Survey, v. 57, p. 1-243.

1926, The plankton algae of the Okoboji region: Transactions of the American Microscopical Society, v. 45, p. 156-233.

1931, Pandorina Charkowiensis Korshikov: Bulletin of the Torrey Botanical Club, v. 57, p. $365-366$.

1950, The freshwater algae of the United States: New York, McGraw-Hill, 719 p. ed., 1951, Manual of phycology - An introduction to the algae and their biology: New York, Ronald Press Co., 373 p.

Stein, F. R. von, 1883, Der Organismus der Infusionsthiere nach eigenen Forschungen in systematischer Reinenfolge bearbetiet. III. Abteilung. II Halfe. Die Naturgeschichte der Arthrodelen Flagellaten: Leipzig, 30 p.

Teiling, E., 1946, Zur Phytoplanktonflora Schwedens: Bot. Notiser, 1946, p. 61-88.

Thienemann, August, 1939, Grundzüge einer allgemeinen Ökologie: Archives Hydrobiologica, v. 35, p. 267-285.

Thompson, R. H., 1938, A preliminary survey of the freshwater algae of eastern Kansas: University of Kansas Science Bulletin no. 25, p. 5-83.

Tiffany, L. H., 1934, The plankton algae of the west end of Lake Erie: Ohio State University, Contributions of the Franz Theodore Stone Laboratory, no. 6, p. 1-112.

Turpin, P. J., 1828, Aperçu organographique sur le nombre deux: Mémoir Muséum d'Hist. Nat. par les Prof. de cet establissement, v. 16, p. 296-344. 
Vaucher, J. P., 1803, Histoire des confervés d'eau douce: Geneva.

Weber, C. I. 1966, A guide to the common diatoms of water pollution surveillance system stations: Cincinnati, Ohio, Federal Water Pollution Control Administration, $101 \mathrm{p}$.

West, G. S., 1908, Some critical green algae: Journal of the Linnean Botanical Society of London, v. 38, p. 279-389.

West, W., and West, G. S., 1905, A further contribution to the freshwater plankton of the Scottish lochs: Transactions of Royal Society of Edinburgh, v. 41, p. 477-518.

1908, A monograph of the British Desmidiaceae, Volume 2: London, Ray Society, $204 \mathrm{p}$.

1912, On the periodicity of the phytoplankton of some British lakes: Journal of Linnean Society of Botany, London, v. 40, p. 395-432.

Whipple, G. C., Fair, G. M., and Whipple, M. C., 1948, The microscopy of drinking water, 4th ed.: New York, John Wiley and Sons, 586 p.

Williams, L. G., 1962, Planktonic population dynamics: U.S. Public Health Service Publication no. 663, supp. 2, 93 p.

-1964, Possible relationships between plankton-diatom species numbers and waterquality estimates: Ecology, v. 45, p. 809-823.

1966, Dominant planktonic rotifers of major waterways of the United States: Lim nology and Oceanography, v. 11, p. 83-91. 

W. B. L. LORAR - WOODS HOLL, WASS. 
